KARINA DE OLIVEIRA BERNADES

\title{
PROTOCOLOS DE LIMPEZA DE DENTINA CONTAMINADA POR DIFERENTES SOLUÇÕES DE EFEITO HEMOSTÁTICO
}

BRASÍLIA, 2014 
UNIVERSIDADE DE BRASÍLIA

FACULDADE DE CIÊNCIAS DA SAÚDE

PROGRAMA DE PÓS-GRADUAÇÃO EM CIÊNCIAS DA SAÚDE

KARINA DE OLIVEIRA BERNADES

\section{PROTOCOLOS DE LIMPEZA DE DENTINA CONTAMINADA POR DIFERENTES SOLUÇÕES DE EFEITO HEMOSTÁTICO}

Dissertação apresentada como requisito parcial para obtenção do Título de Mestre em Ciências da Saúde pelo Programa de Pós-Graduação em Ciências da Saúde da Universidade de Brasília.

Orientador: Profa. Dra. Patrícia Nóbrega Rodrigues Pereira Co-Orientador: Profa. Dra. Ana Paula Dias Ribeiro

BRASÍLIA 
KARINA DE OLIVEIRA BERNADES

PROTOCOLOS DE LIMPEZA DE DENTINA CONTAMINADA POR DIFERENTES SOLUÇÕES DE EFEITO HEMOSTÁTICO

Aprovado em _ $\underline{03}$ de __ Dezembro de _ 2014

Dissertação apresentada como requisito parcial para obtenção do título de Mestre em Ciências da Saúde pelo Programa de Pósgraduação em Ciências da Saúde na Universidade de Brasília.

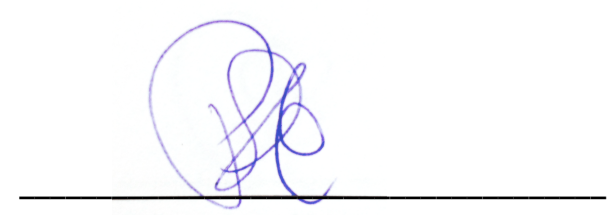

Prof. Dra . Patrícia Nóbrega Rodrigues Pereira

Universidade de Brasília

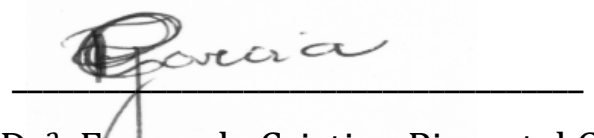

Prof. Drạ. Fernanda Cristina Pimentel Garcia

Universidade de Brasília

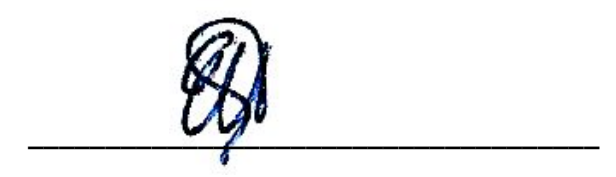

Prof. Dra Érica Miranda de Torres

Universidade Federal de Goiás

BRASÍLIA 
Ao Nada ontológico por ser incorpóreo Contraditoriamente personificado no Tudo ilógico Espacialmente localizado, mas não espacialmente estendido Assim plenamente presente em todos os sentidos Em tempo, atemporal Da Realidade metafísica suprema do Um absoluto Intrinsicamente iningual Ao Ser indivisível dividido em Três Ao Sustentador do Cosmo e Reconciliador da vida Ao outrora Desconhecido, Mas que esvaziando-se, conhecido fez-se À Transcendência Imanente Emanada no Divisor da história Ao Lógus encarnado À Essência única e Causa dupla de todas as coisas De onde tudo vem e para onde tudo converge Ao Alfa e Ômega de toda existência Ao fatalmente não dizível Ao que É, e sem o qual nada do que é seria Dedico. 


\section{AGRADECIMENTOS}

À minha orientadora, professora Patrícia Pereira por ter aceito me orientar, pelo carinho, preocupação e portas abertas com que me recebeu em Brasília. Pela maestria do ensino de humanidade, humildade, bondade, e quem sabe adesão. Agradeço por tanto ter me ensinado, sem ter preciso dizer nada. Muito obrigada pela confiança desmedida, pelo tempo que a mim pôde dispender, por todas oportunidades a mim concedidas e principalmente pela impagável oportunidade de tê-la conhecido. Me orgulho por poder dizer que fostes minha orientadora, não pela grandeza de seu sobrenome, mas pela exuberância de quem és.

À minha co-orientadora, mais que querida, professora Ana Paula Dias Ribeiro pelo apoio, preocupação, acolhimento e amizade. Por tornar os dias no laboratório mais leves, por deixar exalar a paixão que tem pelo que faz. Por me levar pra comer comida de rico, mas também por compartilhar da ingestão de Alumínio. Obrigada pela receptividade e carinho que sempre demonstrou a mim.

À professora Fernanda Garcia pelas conversas informais e conselhos, pelas sugestões e presença sempre agradável, pela alegria e descontração nas tardes laboratoriais...e pela elegância no modelito, apreciável aos olhos do observador.

Ao professor Leandro Hilgert pela ajuda, preocupação e disposição nas resoluções dos problemas metodológicos deste. Pelo envolvimento e oportunas sugestões. Pela oportunidade de resolução de alguns casos clínicos, pelas dicas e todo conhecimento compartilhado. Pelo empréstimo de materiais e equipamentos sempre que necessário.

À professora Palloma Murtelle, Instituto de Engenharia da UnB, pela solicitude, e boa vontade em ajudar. Pelo remanejamento da agenda e concessão da utilização dos equipamentos para realização das análises de MEV. 
Aos professores José Alves Dias e Sílvia Dias do LabCat, Instituto de química da UnB. Pela receptividade, gentileza e auxílio na melhor compreensão das reações químicas envolvidas no presente estudo.

Ao técnico Miguel Garcia, Instituto de Engenharia, pela preocupação, disposição e auxílio na realização das análises de MEV.

À melhor companheira de mestrado e vivência Marília Bizinoto por tão bem ter me recebido, pelos dois anos de aprendizado, amizade, companheirismo, e suporte. Pela ajuda sempre que preciso, por tantas vezes ter facilitado minha vida, pelas boas risadas diárias, e experiências gastronômicas. Por ser minha advogada de defesa e representante oficial para assuntos acadêmicos. Pelo sábio mestre do poney cor-derosa e por sabermos que fazer mestrado é fácil, difícil é encontrar alguém com Tecpix.

À colega de mestrado Alessandra di Paula pelo apoio, incentivo, ajuda, portas abertas e amizade. Pelas conversas, momentos de descontração e por me provar que amigo de verdade entra com você na furada de Farmacologia Molecular.

À colega de mestrado Lívia Malpeli pelas conversas e risadas trocadas, pela doação de alguns dentes para realização deste estudo.

Ao Dr. Cláudio Pinho pela gentileza, dicas e oportunidade de ter aprendido com um dos maiores nomes de Odontologia Estética do mundo.

À amiga Denise Félix por nunca medir esforços para me ajudar. Por ter estado presente em momentos decisivos da continuação da realização deste. Pela amizade, preocupação, incentivo, apoio, desdobramento e doação. Obrigada por estar sempre presente. Você é parte fundamental de tudo isso.

À amiga Laís Santos por todo apoio, irmandade, e disposição em ajudar. Pela amizade e companheirismo sempre.

À Sylvia Nogueira e família por tão bem terem me recebido e acolhido em Brasília. Pelo apoio desmedido, incentivo, carinho e confiança. Pela companhia e força nas extrações dos dentes no frigorífico, pela ajuda no corte dos canos de PVC, por toda 
parcela de contribuição ativa na realização deste trabalho. Pela amizade, fraternidade e laços que ecoam na eternidade.

Aos amigos que fiz nesta cidade linda Camilla, Juliana, João Paulo e Luiz. Vocês foram fundamentais para a conclusão deste trabalho. Obrigada por todo apoio, suporte e preocupação. Pela amizade, momentos de descontração, conselhos e pelo crescimento que tive convivendo com vocês.

À meu querido tio Lourival Bernardes que mesmo distante se faz presente. Obrigada pela torcida, e pela contribuição na realização deste.

À meus avós, tios e primos por saber que sempre terei com quem contar, pelo incentivo e apoio de sempre.

Ao Instituto de Biologia pelo empréstimo dos stubs e concessão da utilização da lupa estereoscópica.

À Universidade de Brasília, na pessoa do Reitor, Prof. Dr. Ivan Marques de Toledo Camargo.

À Faculdade de Ciências da Saúde, na pessoa da Diretora, Profa. Dra. Maria Fátima de Sousa.

Ao Programa de Pós-Graduação em Ciências da Saúde, na pessoa do Coordenador, Prof. Dr. Francisco de Assis Neves.

Ao Decanato de Pesquisa e Pós-Graduação (DPP) pelo auxílio concedido durante o tempo de pesquisa. 


\section{meus agradecimentos especiais...}

À meus pais José Ilon e Gislene Cristina. Vocês foram meus primeiros e melhores professores e orientadores. Com vocês aprendi o que artigo e livro nenhum poderia me ensinar. Vocês sempre me apoiaram, acreditaram e confiaram em mim. Vocês nunca mediram esforços para eu ter tudo o que eu precisava para alcançar meus sonhos. Pai, obrigada por ser sempre exemplo de força e determinação, por me ensinar a nunca desistir e a me esforçar para fazer sempre o melhor que posso. Mãe, você me ensinou o amor, me ensinou que amar é abrir mão e dar sem nada esperar receber. Obrigada por tanto ter aberto mão de você mesma por mim. Vocês me ensinaram o caminho em que eu devo andar, e eu não me desviarei dele. Obrigada por serem os pais que eu nunca poderia imaginar existir. Sem vocês nada disso seria possível.

À meus irmãos Marco Aurélio, Carolina e Samirian pela presença, cuidado e apoio nos momentos difícies, por serem meus melhores amigos e por terem participação decisiva em todas as minhas conquistas.Vocês são a melhor parte de mim.

À professora, orientadora e amiga Érica Miranda de Torres pela confiança, apoio, incentivo, preocupação e conselhos. Você sugeriu o tema de pesquisa dessa dissertação, revisou comigo o meu pré-projeto para a seleção do mestrado e fez a análise estatística dos resultados do mesmo. Por fazer parte da minha história e estar presente em momentos tão importantes da minha vida. Por dedicar o seu tempo e me desejar sempre o melhor e até mais do que eu poderia imaginar. Obrigada por enxergar em mim mais do que eu realmente sou. Serás para mim sempre um referencial de integridade, ética, competência e excelência em tudo o que faz. Minha eterna gratidão pelas portas abertas e caminhos apontados. Dever-te-ei sempre todo o meu respeito, admiração, carinho e amor.

Ao Eterno Criador por tecer como um exímio artesão todas essas pessoas na minha trajetória. Por saber o fim desde o começo e guiar-me à ele encaixando todas as peças e fazendo cooperar para o meu bem todas as coisas da minha vida a fim de cumprir Seu supremo propósito. 
Eu até poderia escrever uma frase bonita de Confúcio, mas confesso: não leio Confúcio. 


\section{RESUMO}

O objetivo deste trabalho foi avaliar a resistência de união ao microcisalhamento (RUMC) do cimento resino autoadesivo RelyX U200 (3M/ESPE) à dentina, em função de diferentes agentes contaminantes e protocolos de limpeza. Cento e cinco incisivos bovinos foram selecionados, limpos e armazenados em solução neutra de timol $0,1 \%$. As superfícies vestibulares dos dentes foram desgastadas em máquina recortadora de gesso, as coroas foram separadas das raízes e incluídas em resina acrílica em tubos de PVC. Lixas de carbeto de silício foram utilizadas para planificação da superfície. Os dentes foram inicialmente divididos aleatoriamente em 5 grupos, quanto ao agente contaminante: C (Controle), V (ViscoStat), VC (ViscoStat Clear), E (Visine), D (Sure). Os 4 grupos contaminados foram então subdivididos em 5 , quanto ao protocolo de limpeza: W (jato spray de água por 15s), A (ácido fosfórico $37 \% \mathrm{C}+$ jato spray de água por 15s (JSA - 15s), E (EDTA por 60 segundos + JSA - 15s.), O (Jateamento com óxido de alumínio por 15s + JSA - 15s), P (profilaxia com pedra pomes por 15s + JSA - 15s). A delimitação da área de adesão foi conseguida com fita adesiva dupla-face. Tubos de amido $(0,96 \mathrm{~mm}$ de diâmetro e $2 \mathrm{~mm}$ de altura) permitiram a confecção dos cilindros de resina, que coincide com a área delimitada. Os testes de resistência ao microcisalhamento foram realizados após 24 horas, em uma máquina de ensaios mecânicos de resistência ao cisalhamento (Bisco Shear Bond Tester) à velocidade de $0,5 \mathrm{~mm} / \mathrm{min}$ e com célula de carga de $50 \mathrm{kN}$. A análise do padrão de fratura foi realizada utilizando lupa estereoscópica (SZX9, Olympus). Com caráter ilustrativo, um dente representativo de grupos previamente selecionados foram separados para observação em MEV. Os dados foram submetidos à ANOVA - 2 critérios e teste de Tukey $(\alpha=0,05)$. Os valores de média \pm desvio padrão para RUMC (MPa) encontrados foram:C $(11,15 \pm 0,52)^{\mathrm{DEFG}}, \mathrm{VW}(2,06 \pm 0,51)^{\prime}, \mathrm{VA}(0,98 \pm 0,39)^{\prime}, \mathrm{VE}(3,71 \pm 0,66)^{\mathrm{HI}}, \mathrm{VO}$ $(9,52 \pm 0,86)^{\mathrm{FG}}, \mathrm{VP}(16,64 \pm 0,94)^{\mathrm{GHI}}, \mathrm{VCW}(3,35 \pm 1,06)^{\mathrm{AB}}, \mathrm{VCA}(7,06 \pm 0,99)^{\mathrm{BC}}, \mathrm{VCE}$ $(2,85 \pm 0,90)^{\mathrm{A}}$, VCO $(12,06 \pm 1,01)^{\mathrm{CDEF}}, \operatorname{VCP}(10,22 \pm 0,81)^{\mathrm{EFG}}, \mathrm{EW}(16,11 \pm 0,82)^{\mathrm{ABC}}$ $\mathrm{EA}(4,34 \pm 0,70)^{\mathrm{HI}}, \mathrm{EE}(1,35 \pm 0,34)^{\prime}, \mathrm{EO}(13,98 \pm 0,76)^{\mathrm{ABCDE}}, \mathrm{DW}(12,90 \pm 1,08)^{\mathrm{BCDEF}}$, $\mathrm{DA}(11,98 \pm 1,11)^{\mathrm{CDEF}}, \mathrm{DE}(1,72 \pm 0,50)^{\prime}$, DO $(17,78 \pm 0,95)^{\mathrm{A}}$, DP $(14,42 \pm 0,55)^{\mathrm{ABCD}}$. Os contaminantes $\mathrm{V}$ e VC demonstraram os piores resultados. O protocolo de limpeza $\mathrm{A}$ 
deveria ser evitado e não utilizado para o contaminante $\mathrm{V}$. O protocolo $\mathrm{E}$ não deveria ser utilizado para o material RelyX U200. Os protocolos $P$ e O demonstraram ser eficicientes para todos os contaminantes. Considerando as limitações do presente estudo pode-se concluir que na presença de contaminação com agentes hemostáticos, a utilização de um protocolo de limpeza adequado é de fundamental importância para estabelecer uma resistência de união aceitável do cimento RelyX U200 à dentina. Saber as possíveis interações do agente contaminante com o método de limpeza é essencial para melhor escolha deste.

Palavras-chaves: cimentos de resina; dentina; agentes hemostáticos; protocolos de limpeza. 


\section{ABSTRACT}

The aim of this study was to evaluate the microshear bond strength of self-adhesive cement RelyX U200 (3M/ESPE) to dentin, due to different hemostatic agents and cleasing protocol. One hundred and five bovine incisors were selected, cleaned and stored in neutral solution of $0.1 \%$ thymol. The buccal surfaces of the teeth were worn out in a plaster trimmer machine, the crowns were separated from the roots and embedded with acrylic resin in PVC tubes. It was used silicon carbide sandpaper for obtaining flat buccal surfaces. The teeth were ramdomly divided into 5 groups, according to the hemostatic agent: C (Control - no contamination), V (ViscoStat), VC (ViscoStat Clear, E (Visine), D (Sure). The 4 contaminated groups were then subdivided into 5 , according the cleasing protocol: W (water spray for $15 \mathrm{~s}$ ), A (phosphoric acid $37 \%$ for $15 \mathrm{~s}+$ water spray for 15s), E (EDTA for $15 s+$ water spray 15s), O (Aluminum oxide abrasion for $15 s$ + water spray for 15s), P (Pumice prophylaxis for $15 s+$ water spray for $15 \mathrm{~s}$ ). The delimitation of bonding area was achieve with adhesive double-sided tape. Starch tubes (0,96 mm diameter and $2 \mathrm{~mm}$ height) allowed manufacturing of cement cylinders, which coincide with delimited areas. The microshear strength tests were performed after $24 \mathrm{~h}$, a mechanical testing machine (Bisco Shear Bond Tester), speed $0,5 \mathrm{~mm} / \mathrm{min}$ and load cell of $50 \mathrm{kN}$. The analysis of the fracture was performed using a stereomicroscope (SZX9, Olympus). With illustrative, one representative tooth of previously selected groups were observed in scanning electron microscopy. Data were analyzed by two-way ANOVA and Tukey tests $(\alpha=0,05)$. Results for microshear bond strength were: $C(11,15 \pm 0,52)^{\mathrm{DEFG}}$, VW $(2,06 \pm 0,51)^{\prime}$, VA $(0,98 \pm 0,39)^{\prime}, \operatorname{VE}(3,71 \pm 0,66)^{\mathrm{HI}}$, VO $(9,52 \pm 0,86)^{\mathrm{FG}}, \mathrm{VP}(16,64 \pm$ $0,94)^{\mathrm{GHI}}, \operatorname{VCW}(3,35 \pm 1,06)^{\mathrm{AB}}, \operatorname{VCA}(7,06 \pm 0,99)^{\mathrm{BC}}, \operatorname{VCE}(2,85 \pm 0,90)^{\mathrm{A}}, \operatorname{VCO}(12,06 \pm$ $1,01)^{\mathrm{CDEF}}, \mathrm{VCP}(10,22 \pm 0,81)^{\mathrm{EFG}}, \mathrm{EW}(16,11 \pm 0,82)^{\mathrm{ABC}}, \mathrm{EA}(4,34 \pm 0,70)^{\mathrm{HI}}, \mathrm{EE}(1,35 \pm$ $0,34)^{\prime}$, EO $(13,98 \pm 0,76)^{\mathrm{ABCDE}}, \mathrm{DW}(12,90 \pm 1,08)^{\mathrm{BCDEF}}, \mathrm{DA}(11,98 \pm 1,11)^{\mathrm{CDEF}}, \mathrm{DE}(1,72$ $\pm 0,50)^{\prime}, \mathrm{DO}(17,78 \pm 0,95)^{\mathrm{A}}, \mathrm{DP}(14,42 \pm 0,55)^{\mathrm{ABCD}}$. Most fractures were type adhesive. The contaminants $V$ and VC showed the worst results. The cleasing protocol $A$, should be avoid and not used to $\mathrm{Fe}_{2}\left(\mathrm{SO}_{4}\right)_{3}$. The protocol $\mathrm{E}$ should not be used to the material RelyX U200. The protocols $P$ and $O$ showed be efficient to all types of contaminants. Considering the limitations of this study it is concluded that in the presence of 
hemostatic agent contamination, the use of an adequated cleasing protocol is totally important to the establishment of an acceptable bond strength of RelyX U200 to dentin. Furthermore the knowledge of the possible interactions between contaminant and cleasing protocol is essential for better choice of this one.

Keywords: resin cements; dentin; hemostatic agents; cleasing protocols. 


\section{LISTA DE FIGURAS}

Figura 1 Resultados dos testes de resistência de união dos estudos realizados em dentina incluídos na revisão sistematica. (Bernades KO, Hilgert LA, Ribeiro APD, Garcia FCP, Pereira PNR. The influence of hemostatic agents on dentin and enamel surfaces and dental bonding: $A$ systematic review. JADA. 2014; vol. 145, n. 11, pp. 1120-1128)

$\begin{array}{lll}\text { Figura } 2 & \text { Padronização da smear layer } & 41\end{array}$

$\begin{array}{lll}\text { Figura } 3 \text { Contaminação com ViscoStat } & 41\end{array}$

Figura 4 Contaminação com ViscoStat Clear 42

Figura 5 Contaminação com Visine 42

Figura 6 Procedimentos para contaminação do grupo D. A - Coleta da pasta do desodorante. B - Manipulação em placa de vidro com espátula $n^{\circ} 24$. C - Aplicação do produto sobre a dentina. D - Espera do tempo de contaminação por 2 minutos

$\begin{array}{lll}\text { Figura } 7 & \text { Jato spray de água por } 15 \text { segundos } & 43\end{array}$

Figura 8 Procedimentos para limpeza com ácido fosfórico 37\% 44

Figura 9 Procedimentos para limpeza com EDTA. Devido sua ligação com íons de ferro, uma visível reação química foi observado para o grupo ViscoStat

Figura 10 Procedimentos para limpeza com óxido de alumínio $90 \mu \mathrm{m} \quad 45$

Figura 11 Procedimentos para limpeza com pedra-pomes 45

$\begin{array}{lll}\text { Figura } 12 & \text { Perfuração da fita auto-adesiva dupla face } & 47\end{array}$

Figura 13 Sequência de confecção dos cilindros de cimento auto-adesivo RelyX U200. A- Posicionamento da fita auto-adesiva dupla-face sobre a dentina tratada, B- Fixação dos tubos de amido sobre a fita. C- Total concordância do orifício da fita e diâmetro interno do tubo. D- Inserção do cimento resinoso com auxílio de brunidor. E- Remoção de excesso de cimento com microbrush. F- Fotopolimerização por 20 segundos

Figura 14 Remoção do tubo de amido após 24 horas

Figura 15 Suporte metálico para imobilização do cilindro de resina acrílica e posterior encaixe na máquina de cisalhamento 
Figura 16 Máquina Bisco Shear Bond Tester

Figura 17 Ponta ativa em forma de cinzel em justaposição à superfície dentinária, paralelamente à interface adesiva

Figura 18 À esquerda, ponta ativa em semi-círculo para cisalhamento. À direita, ponta ativa fabricada em forma de cinzel para micro-cisalhamento

Figura 19 Região de dentina em que os procedimentos adesivos foram realizados, montada em stub metálico e metalizadas com fina camada de platina

Figura 20 Equipamento utilizado para análise de MEV

Figura 21 Resistência de união ao microcisalhamento dos diferentes subgrupos avaliados no estudo

Figura 22 Interação entre as variáveis de estudo Contaminante e Limpeza, e sua influência na resistência de união ao microcisalhamento

Figura 23 Superfície dentinária do Grupo Controle. Presença de smear layer e maioria dos túbulos dentinários totalmente ocluídos

Figura 24 Após 2 minutos de exposição à ViscoStat, seguido de jato spray de água por 15 segundos

Figura 25 Após 2 minutos de exposição à ViscoStat Clear, seguido de jato spray de água por 15 segundos

Figura 26 Após 2 minutos de exposição à Visine, seguido de jato spray de água por 15 segundos

Figura 27 Após 2 minutos de exposição à Sure, seguido de jato spray de água por 15 segundos

Figura 28 Protocolo de limpeza ácido fosfórico 37\% (Grupo VF)

Figura 29 Protocolo de limpeza jateamento com óxido de alumínio $90 \mu \mathrm{m}$ (Grupo VCO)

Figura 30 Protocolo de limpeza EDTA (Grupo EE)

Figura 31 Protocolo de limpeza pedra-pomes (Grupo VP) 


\section{LISTA DE TABELAS}

Tabela 1 Agentes hemostáticos comercializados mais utilizados na Odontologia e seus respectivos constituintes

Tabela 2 Materiais utilizados no estudo 39

Tabela 3 Grupos experimentais contaminados 46

Tabela 4 Valores de média, (desvio-padrão) e intervalo de confiança 95\% para média da resistência de união (MPa) ao microcisalhamento dos grupos testados

Tabela 5 Porcentagem geral dos tipos de fratura 


\section{LISTA DE ABREVIATURAS E SIGLAS}

\begin{tabular}{|c|c|}
\hline $\mathrm{mm}$ & Milímetro \\
\hline$\mu \mathrm{m}$ & Micrômetro \\
\hline $\mathrm{s}$ & Segundos \\
\hline $\min$ & Minutos \\
\hline kN & Quilo-Newtons \\
\hline $\mathrm{N}$ & Newtons \\
\hline $\mathrm{MPa}$ & MegaPascal \\
\hline $\mathrm{mW} / \mathrm{cm}^{2}$ & Miliwatts por centímetro quadrado \\
\hline $\mathrm{mm} / \mathrm{min}$ & Milímetro por minuto \\
\hline LED & Luz emissora de Diodo \\
\hline PVC & Policloreto de Vinila \\
\hline MEV & Microscopia Eletrônica de Varredura \\
\hline ANOVA & Análise de Variância \\
\hline $\mathrm{p}$ & Nível de significância \\
\hline RUMC & Resistência de união ao microcisalhamento \\
\hline EDTA & Ácido Etilenodiaminotetraacético \\
\hline $\mathrm{pH}$ & Potencial hidrogeniônico \\
\hline $\mathrm{Fe}_{2}\left(\mathrm{SO}_{4}\right)_{3}$ & Sulfato de ferro \\
\hline
\end{tabular}




\begin{tabular}{ll}
$\mathrm{AlCl}_{3}$ & Cloreto de Alumínio \\
$\mathrm{H}_{3} \mathrm{PO}_{4}$ & Ácido fosfórico \\
$\mathrm{HCl}$ & Ácido Clorídrico \\
$\mathrm{AlPO}_{4}$ & Alumino Fosfato \\
$\mathrm{Zn}$ & Zinco \\
$\mathrm{Co}$ & Cobalto \\
$\mathrm{Ni}$ & Níquel \\
$\mathrm{Cd}$ & Cádmio \\
$\mathrm{Sn}$ & Estanho \\
$\mathrm{Ca}$ & Cálcio \\
$\mathrm{Sr}$ & Estrôncio \\
$\mathrm{Ba}$ & Bário \\
$\mathrm{Mg}$ & Magnésio \\
$\mathrm{Bi}$ & Bismuto \\
$\mathrm{Fe}$ & Ferro \\
$\mathrm{Pb}$ & Chumbo \\
\hline
\end{tabular}




\section{SUMÁRIO}

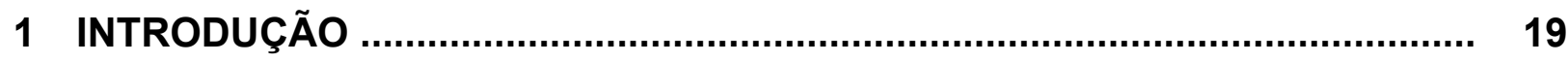

2 REVISÃO DA LITERATURA …............................................................. 21

2.1 INFLUÊNCIA DE AGENTES HEMOSTÁTICOS NA ADESÃO ................... 21

2.2 PRODUTOS COM SUBSTÂNCIAS POTENCIALMENTE 25 CONTROLADORAS DE FLUIDOS

2.3 CIMENTOS RESINOSOS AUTOADESIVOS ......................................... 27

2.4 ENSAIOS LABORATORIAIS PARA DETERMINAÇÃO DA RESISTÊNCIA 32 DE UNIÃO ADESIVA

3 OBJETIVOS 36

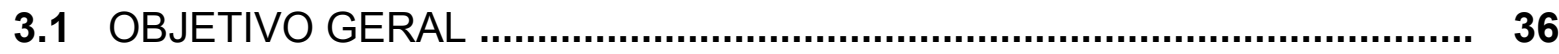

3.2 OBJETIVOS ESPECÍFICOS …........................................................ 36

4 MATERIAIS E MÉTODOS …................................................................. 38

4.1 PREPARO DOS DENTES .................................................................... 38

4.2 DELINEAMENTO EXPERIMENTAL …................................................. 39

4.3 CONFECÇÃO DOS CORPOS DE PROVA …....................................... 40

4.4 RESISTÊNCIA DE UNIÃO AO MICROCISALHAMENTO ........................ 48

4.5 ANÁLISE DO PADRÃO DE FRATURA .............................................. 52

4.6 ANÁLISE DE MICROSCOPIA ELETRÔNICA DE VARREDURA ............... 52

4.7 ANÁLISE ESTATÍSTICA ….............................................................. 54

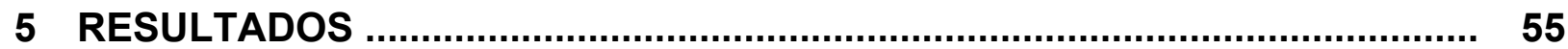

5.1 RESISTÊNCIA DE UNIÃO AO MICROCISALHAMENTO ......................... 55

5.2 ANÁLISE DO PADRÃO DE FRATURA ............................................. 58

5.3 ANÁLISE DE MICROSCOPIA ELETRÔNICA DE VARREDURA .............. 59

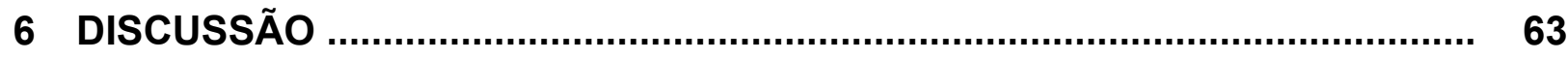

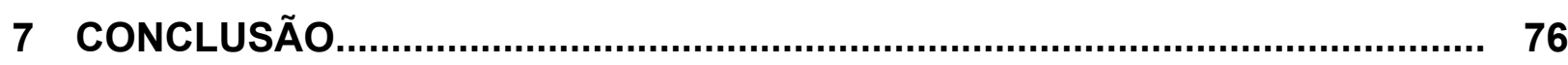
REFERÊNCIAS 


\section{INTRODUÇÃO}

Durante os procedimentos de cimentação de restaurações indiretas, fluidos gengivais e sangue algumas vezes podem aparecer como um resultado de trauma proveniente da preparação do dente na região cervical. Em muitos casos a utilização do dique de borracha é difícil ou até mesmo impossível. O procedimento mais comum e frequentemente utilizado para controlar o sangramento e diminuir o fluxo do fluido gengival, nestes casos, envolve a utilização de um agente hemostático tópico $(1,2)$.

Agentes hemostáticos cada vez mais são utilizados como um método de fácil controle de fluidos em procedimentos odontológicos, contudo muitos estudos tem demonstrado que esses agentes podem permanecer na superfície do dente e provocar uma diminuição significativa na resistência de união de sistemas adesivos à dentina contaminada (1-5).

Acredita-se que os contaminantes impedem o escoamento do monômero resinoso para dentro dos túbulos dentinários, através de pequenas partículas que penetram os túbulos, afetando a formação da camada híbrida (6), fundamental para se conseguir uma adesão durável entre dentina e adesivo resinoso $(7,8)$.

Embora alguns efeitos colaterais tenham sido relatados durante os procedimentos adesivos e moldagem, incluindo inflamação do tecido e viabilidade celular, é estabelecido que o uso adequado desses materiais pode minimizar os efeitos negativos, e maximizar suas vantagens. Alguns efeitos adversos, tais como inflamação e necrose tecidual, foram resolvidos por menores concentrações e formulações do tipo gel comercializados pelo fabricante (9). Outros efeitos, como a interferência sobre a adesão, necessitam ainda de maior clarificação a respeito de um método de limpeza confiável que possa ser indicado.

Diversas pesquisas tem relatado o efeito de agentes hemostáticos sobre a adesão de materiais restauradores diretos, todavia pouco se têm pesquisado a respeito destes mesmos efeitos sobre a adesão de materiais restauradores indiretos, embora o 
seu uso seja freqüente nos procedimentos de cimentação de inlays, onlays, facetas, coroas e peças protéticas em geral. Portanto, torna-se importante a investigação da influência de agentes hemostáticos sobre cimentos resinosos, assim como a elucidação de um protocolo de limpeza eficaz. 


\section{REVISÃO DA LITERATURA}

\subsection{INFLUÊNCIA DE AGENTES HEMOSTÁTICOS NA ADESÃO}

Agentes hemostáticos são soluções ácidas com pH variando de 0.7 a 3.0 (3) (10) (11). Quimicamente, esses agentes possuem ação farmacológica dividida em duas categorias: Classe I - vasoconstritores (agentes adrenérgicos), e Classe II adstringentes (fatores de coagulação sanguínea) (12).

Vasoconstritores como epinefrina não possuem ação coagulante, mas agem contraindo os vasos sanguíneos e diminuindo o seu tamanho. Todavia, o uso da epinefrina é limitado, pois pode causar hipertensão e taquicardia (13). Preferência deveria ser dada a agentes adstringentes baseados em sais de metal quando comparado à epinefrina, pois apresentam efeito terapêutico similar e menores efeitos sistêmicos adversos (14).

Adstringentes, tais como alúmen ou Sulfato duplo de Alumínio e Potássio (KAl $\left.\left(\mathrm{SO}_{4}\right)_{2}\right)$, Cloreto de Alumínio $\left(\mathrm{AlCl}_{3}\right)$, Cloreto de Zinco $\left(\mathrm{ZnCl}_{2}\right)$, são substâncias que agem por precipitação das proteínas sobre a camada superficial da mucosa. Estípticos como o Cloreto de Ferro e Sulfato férrico, são formas concentradas de adstringentes, que causam coagulação local e superficial (15).

Cloreto de Alumínio e Sulfato de Ferro são os principais ingredientes ativos dos mais usuais hemostáticos utilizados na Odontologia (9), devido à um dano tecidual considerado mínimo (15) e também ao fácil uso e resultados efetivos (16). Existe uma vasta gama de produtos com base nestes dois componentes de diferentes fabricantes, na Tabela 1 estão relatados alguns dos mais comercialmente utilizados (Tabela 1). 
Tabela 1 - Agentes hemostáticos comercializados mais utilizados na Odontologia e seus respectivos constituintes.

\section{\begin{tabular}{lll}
\hline \hline NOME COMERCIAL & FABRICANTE & CONSTITUINTE
\end{tabular}}

\begin{tabular}{|c|c|c|}
\hline Hemodent & $\begin{array}{l}\text { Premier Dental Products, } \\
\text { Plymouth Meeting, Pa. }\end{array}$ & $21,3 \% \mathrm{AlCl}_{3}$ \\
\hline Hemostop & $\begin{array}{l}\text { Dentsply International, } \\
\text { York, Pa. }\end{array}$ & $\mathrm{AlCl}_{3}$ \\
\hline Viscostat & $\begin{array}{l}\text { Ultradent Products, South } \\
\text { Jordan, Utah. }\end{array}$ & $20 \% \mathrm{Fe}_{2}\left(\mathrm{SO}_{4}\right)_{3}$ \\
\hline Viscostat Clear & $\begin{array}{l}\text { Ultradent Products, South } \\
\text { Jordan, Utah. }\end{array}$ & $20 \% \mathrm{AlCl}_{3}$ \\
\hline Viscostat Plus & $\begin{array}{l}\text { Ultradent Products, South } \\
\text { Jordan, Utah. }\end{array}$ & $22 \% \mathrm{FeCl}_{3}$ \\
\hline Astringedent & $\begin{array}{l}\text { Ultradent Products, South } \\
\text { Jordan, Utah. }\end{array}$ & $15,5 \% \mathrm{Fe}_{2}\left(\mathrm{SO}_{4}\right)_{3}$ solution \\
\hline Racestyptine & $\begin{array}{l}\text { Septodont, Saint-Maur- } \\
\text { des-Fossés, France. }\end{array}$ & $25 \% \mathrm{AlCl}_{3}$ \\
\hline Hemogin L & Dux Dental, Oxnard, Calif. & $25 \% \mathrm{AlCl}_{3}$ \\
\hline
\end{tabular}

Cloreto de Alumínio é um dos adstringentes mais comumente utilizados, pois é um dos menos irritantes entre os agentes hemostáticos utilizados com fio retrator e, por ser incolor, não apresenta a desvantagem dos hemostáticos à base de Sulfato de ferro, que devido ao teor deste metal de transição podem induzir à coloração amarelo-marrom 
ou preto do tecido gengival circundante (17), assim como manchamento de restaurações estéticas (18). Costuma ser utilizado em uma concentração de 5-25\%, e possui efeitos sistêmicos mínimos $(19,20)$.

$\mathrm{Na}$ presença de água estes compostos, $\mathrm{AlCl}_{3}$ e $\mathrm{Fe}_{2}\left(\mathrm{SO}_{4}\right)_{3}$, sofrem hidrólise, podendo formar ácido hidroclórico e ácido sulfúrico, respectivamente (21). Devido à seus subprodutos com potencial corrosivo, pela liberação de $\mathrm{H}^{+}$, esses agentes podem ter efeito acidificante sobre a estrutura dentinária, como é observado pela análise de microscopia eletrônica de varredura em alguns estudos (1, 2, 5, 8, 22).

Ao mesmo tempo, partículas remanescentes dos agentes hemostáticos podem obstruir a fluidez dos monômeros resinosos para dentro dos túbulos dentinários afetando no desenvolvimento da camada híbrida (23). Prabhakar e Bedi, 2008 apontaram que agentes hemostáticos à base de Sulfato de ferro, podem coagular as proteínas presentes no plasma no fluido dentinário, assim como ocasionar uma modificação na morfologia superficial da dentina diminuindo a resistência de união de sistemas adesivos (6). Por sua vez, agentes hemostáticos à base de Cloreto de alumínio podem depositar alumínio na forma de mineral não reagido na superfície dentinária, levando à formação de uma camada de resíduos o que, de igual forma, interferiria na resistência de união de sistemas adesivos (24).

Bernades et al., 2014 revisaram sistematicamente a influência de agentes hemostáticos sobre a superfície de dentina e esmalte e na adesão dental. Os autores verificaram que procedimentos adesivos podem ser adversamente afetados quando realizados em dentina e em esmalte contaminados por agentes hemostáticos. Segundo os autores, agentes hemostáticos podem induzir mudanças na morfologia superficial da dentina tanto em aspecto estrutural, como também, observaram que análises de EDS têm demonstrado uma dramática redução no conteúdo de cálcio da composição dentinária, quando da utilização desses agentes (25).

Os resultados da revisão também indicam que a resistência de união de sistemas adesivos auto-condicionantes parecem ser mais negativamente afetados do que os sistemas adesivos de condicionamento total (25). Estudos sugerem que 
monômeros auto-condicionantes podem não ser capazes de remover suficientemente esses contaminantes, devido à sua capacidade adesiva depender da formação de pequenos tags resinosos e à uma camada híbrida relativamente fina. Assim, sistemas adesivos auto-condicionantes parecem ser mais suscetíveis à redução da resistência de união por interferência de agentes hemostáticos (25). Contudo, ácido fosfórico com $\mathrm{pH}$ de 0,5 , e um efeito acidificante mais agressivo, parece ser capaz de desmineralizar a dentina e remover basicamente todos os contaminantes da superfície dentinária (4). A Figura 1 demonstra a influência na resistência de união à dentina contaminada por diferentes agentes hemostáticos, utilizando-se diversos sistemas adesivos (25).

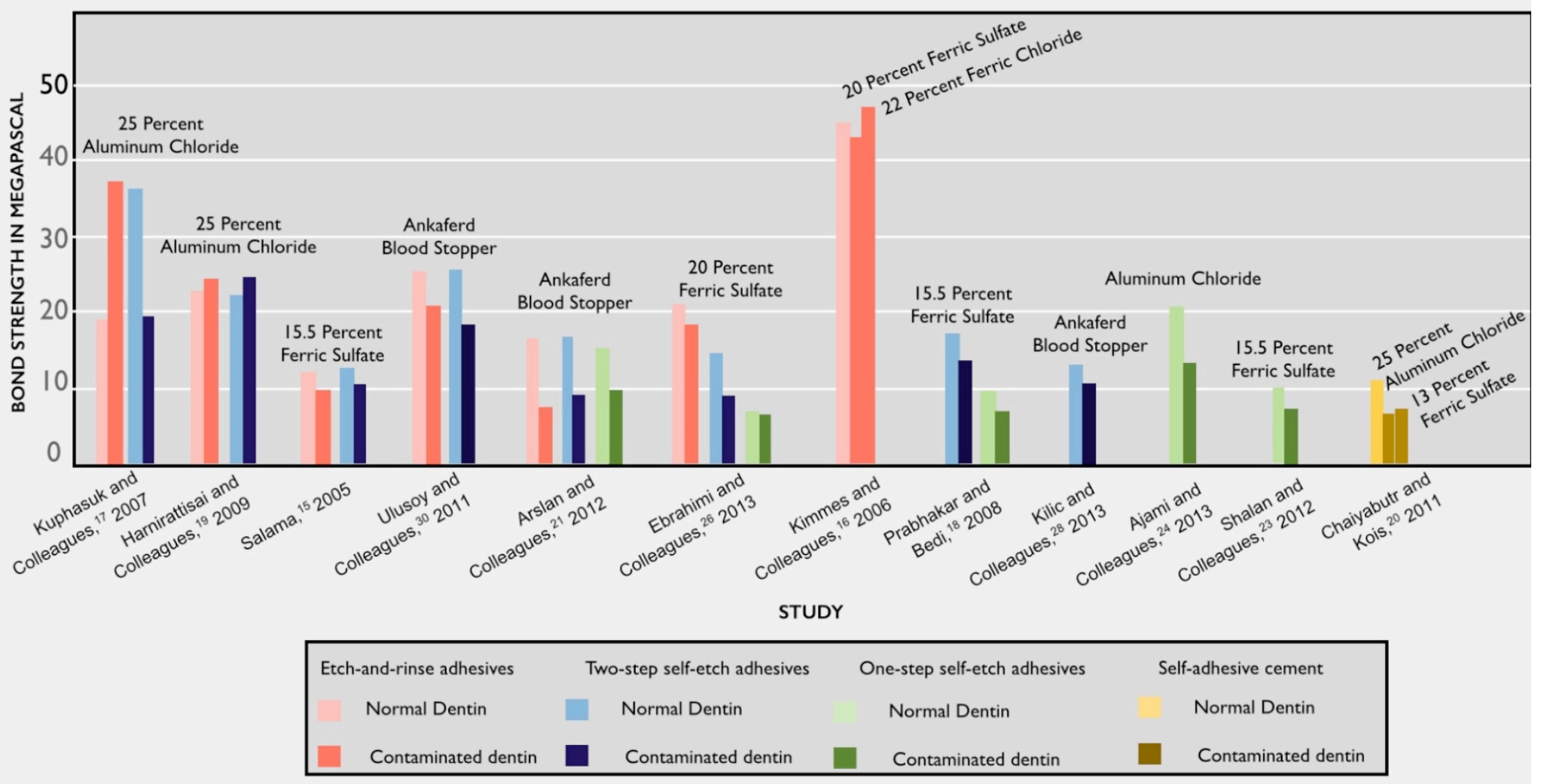

Figura 1. Resultados dos testes de resistência de união dos estudos realizados em dentina, incluídos na revisão sistemática (25). 
Apenas um estudo avaliou a resistência de união de um cimento resinoso autoadesivo, relatando uma significativa diminuição na resistência de união para o grupo lavado somente com água (8). Entretanto, anteriormente ao procedimento adesivo, os espécimes foram contaminados com sangue e somente depois com hemostático, assim sendo a resistência de união aferida deveria ser atribuída à ambas contaminações, e não somente ao agente hemostático, notando-se a necessidade de que mais estudos sejam realizados para esse material (25).

$\mathrm{Na}$ maioria dos casos a limpeza somente com água não foi suficiente para remover a contaminação (25). De acordo com Ajami et al., a aplicação de $10 \%$ de ácido de etilenoaminotetraacetico (EDTA) por 60 segundos seguido por água por 30 segundos restaurou a resistência de união de um sistema adesivo auto-condicionante à dentina (24). Chaiyabutr e Kois, relataram que após a contaminação com $25 \%$ de cloreto de alumínio e $13 \%$ de sulfato férrico, o protocolo de limpeza deveria incluir jateamento com particulas de óxido de alumínio ou ácido fosfórico quando utilizado um cimento resinoso auto-adesivo (8). Devido à escassa literatura elucidando a ação de protocolos de limpeza para diferentes tipos de hemostáticos, vê-se a necessidade de melhor avaliar a ação desses métodos descontaminantes.

\subsection{PRODUTOS COM SUBSTÂNCIAS POTENCIALMENTE CONTROLADORAS DE FLUIDOS}

Com a finalidade de encontrar um agente retrator mais apropriado, a possibilidade de uso de vasoconstritores simpatomiméticos deveria ser considerada (14). Novos agentes hemostáticos tais como a tetrahidrozolina e oxymetazolina possuem um $\mathrm{pH}$ mais aceitável e devem ter ação mais amena com a estrutura do dente e tecido adjacente doque as soluções convencionais (21). 
Tetrahidrozolina pertence ao grupo de vasoconstritores simpatomiméticos, assumindo a eficácia desejada dos agentes hemostáticos, sem todavia, ocasionar os efeitos locais e sistêmicos adversos destes (14). Bowles et al., mostraram um efeito clínico satisfatório de vasoconstrição local forte e ausência de reações sistêmicas (26). Tardy et al., demonstrou maior eficiência de retração gengival, analisando a Tetrahidrozolina, com ausência de efeitos não desejados, comparados à epinefrina (27).

Avaliando a citotoxicidade de agentes retratores vasoconstritores, Nowakowska et al, constatou menor potencial citotóxico para $0.05 \% \mathrm{H}$-Cl-tetrahidrozolina (28). Desde 1996 tem-se sugerido o uso da Tetrahidrozolina como agente hemostático na Odontologia (1), cuja eficácia foi testada por Bowles et al., em 1991 (26).

O desenvolvimento de uma camada híbrida em uma estrutura dentinária previamente acidificada pode dificultar a retenção de próteses cimentadas com certos cimentos resinosos (1). Devido ao seu neutro $\mathrm{pH}$, sua incapacidade de agir na remoção de smear layer parece ser mais vantajoso quando comparado aos agentes hemostáticos baseados em $\mathrm{AlCl}_{3}$ e $\mathrm{Fe}_{2}\left(\mathrm{SO}_{4}\right)_{3} \quad(1,27)$. Assim, torna-se interessante a avaliação da influência desse possível agente hemostático, encontrado comercialmente como colírio na resistência de união de cimentos resinosos à dentina (25).

Além do possível uso de colírio contendo tetrahidrozolina em sua formulação, como agente hemostático, o Cloreto de Alumínio, já utilizado na Odontologia, é a forma parcialmente neutralizada utilizada também em produtos cosméticos antitranspirantes (29). No que diz respeito ao seu mecanismo de ação, vários estudos têm demonstrado que os sais de alumínio causam uma obstrução dos ductos das glândulas (30). O mecanismo subjacente à esta obstrução é hipotetizado ser devido à precipitação dos ions metálicos com mucopolissacarídeos, danificando as células epiteliais ao logo do lúmen do conduto formando um tampão que bloqueia a saída de fluidos (29).

Como visto, sabe-se que contaminantes como o sangue e o fluido gengival crevicular ocluem os túbulos dentinários evitando os tags de resinas de penetrar dentro das fibrilas colágenas, interferindo assim no processo de adesão e diminuindo a 
resistência de união (4) (31). Assim, agentes hemostáticos são utilizados na Odontologia não somente para controle do sangue, mas também para o controle do fluxo de fluidos gengivais e creviculares $(8,32)$.

Dentre os produtos cosméticos antiperspirantes mais utilizados estão os desodorantes. A nova geração de antiperspirantes inclui Triclorohidrex de alumínio zircônio e pode ser uma opção para problemas de hiperhidrose em qualquer parte do corpo (33). Devido à sua composição química e mecanismo de ação, presume-se que tal produto atue, de igual forma, com eficácia, quando aplicados no sulco gengival, impedindo o fluxo de fluido crevicular, possibilitando que procedimentos adesivos sejam feitos em superfícies não contaminadas por tais fluidos.

\subsection{CIMENTOS RESINOSOS AUTO-ADESIVOS}

O grande número de materiais estéticos indiretos que têm sido introduzidos na Odontologia tem direcionado a um uso crescente de cimentos resinosos nos tratamentos restauradores contemporanêos. A princípio, estes agentes de cimentação parecem ser mais desejáveis por serem insolúveis aos fluidos orais, apresentarem biocompatibilidade, facilidade de manuseio, estética, produzirem uma alta resistência de união ao esmalte e dentina e ainda se unir ao material restaurador (34).

O desempenho clínico de restaurações indiretas guarda íntima relação com as diferentes etapas operacionais, clínicas e laboratoriais, mas depende em grande parte da técnica de cimentação utilizada para estabelecer uma efetiva união entre restauração e o dente (35). Devido à complexidade da técnica de cimentos resinosos convencionais, falhas na formação da camada híbrida são passíveis de ocorrer: infiltração incompleta do adesivo na dentina desmineralizada, degradação do colágeno exposto, polimerização inadequada do adesivo (36). 
Atualmente, diversos cimentos resinosos têm sido introduzidos no comércio e são classificados em duas categorias, como descrito no estudo de Manso et al., 2011: os cimentos resinosos convencionais, que não apresentam uma adesão inerente à estrutura dental e requerem o uso de um sistema adesivo e os cimentos resinosos autoadesivos, que não requerem um tratamento adesivo prévio do substrato dentário (37).

Tendo em vista os aspectos acima apresentados, os cimentos resinosos autoadesivos foram fabricados na tentativa de superação das intercorrências observadas com os sistemas convencionais, assim como de promover a simplificação dos passos clínicos e diminuir os efeitos adversos relacionados ao material e ao operador. Do ponto de vista clínico, tem-se destacado, como maior vantagem desse tipo de cimento, a aplicação fácil e rápida, haja vista a eliminação de etapas prévias comumente empregadas com os cimentos resinosos convencionais, fato que o distingue como um dos materiais mais desejáveis na prática odontológica (38).

De forma abrangente os cimentos resinosos auto-adesivos surgiram com a intenção de eliminar as deficiências dos agentes cimentantes tradicionais e dos cimentos resinosos convencionais, em função das características favoráveis de diferentes tipos de cimentos em um único produto: a resistência dos cimentos resinosos, a praticidade como no cimento fosfato de zinco (39), a interação química com o cálcio da hidroxiapatita do dente, além da liberação de flúor (presente em alguns cimentos autoadesivos) como nos cimentos de ionômero de vidro $(35,40)$.

Esse novo subgrupo de cimentos resinosos surgiu em 2002, com o RelyX Unicem (3M ESPE, St.Paul, MN, USA). O seu desenvolvimento seguiu o mesmo raciocínio da simplificação dos sistemas adesivos e, ao despertar grande interesse no mercado, surgiram vários outros cimentos nesta categoria, dentre eles: BisCem (Bisco Inc., Schaumburg, IL, USA), G-Cem (GC, Alsip, IL, USA) Maxcem Elite (Kerr, Orange, CA, USA), Multilink Sprint (Ivoclar Vivadent, Schaan, Liechstenstein, Germany) e Smart Cem 2 (Dentsply, Konstanz, Germany). Buscando uma forma ainda mais simples, o RelyX Unicem (3M ESPE, St. Paul, MN, USA) foi reformulado, sendo apresentado como RelyX U100 (3M ESPE, St. Paul, MN, USA), disponibilizado em duas pastas (base e 
catalisadora), e não mais pó e líquido, em embalagem com dispensador tipo clicker, que evita desperdícios e oferece precisão no proporcionamento, além de maior facilidade na manipulação. Mais recentemente, em 2012, foi lançado o RelyX U200 (3M ESPE, St. Paul, MN, USA) o qual, segundo o fabricante, apresenta melhor resistência de união ao esmalte e reologia similar entre as duas pastas, facilitando ainda mais a sua manipulação.

Segundo Ferracane et al., 2011 os cimentos resinosos autoadesivos apresentam em sua composição monômeros convencionais mono-, di-, e/ou multi-metacrilatos, já utilizados em uma variedade de materiais dentários resionosos: Bis-GMA, oligômeros uretanos de Bis-GMA, UDMA (dimetacrialto de uretano), HEMA (hidroxietil metacrilato), GDMA (glicerol dimetacrilato), TEGDMA (trietileno glycol dimetacrilato), TMPTMA (trimetilolpropano trimetacrilato), dentre outros. Os monômeros ácidos funcionais atualmente utilizados na desmineralização e adesão à superfície dentária são predominantemente os monômeros metacrilatos tanto com grupos ácido carboxílicos, assim como 4-metacriloxietil anidrido trimelítico (4-META) e dimetacrilato glycerol pirometílico (PMGDM), quanto com grupos ácidos fosfóricos, como Fenil-P (2metacriloxietil fenil hidrogênio fosfato), MDP (10-metacriloxidecil dihidrogênio fosfato), BMP (bis(2-metacriloxietil)ácido fosfato) e Penta-P (monofosfato de dipentaeritriol pentacrilato) (41). Há um número substancial de novos monômeros acídicos, principalmente aqueles baseados em fosfatos e fosfanatos que têm sido desenvolvidos, em especial, para realizar a desmineralização de esmalte e dentina bem como para promover a formação de um sal estável, principalmente envolvendo o cálcio (40).

O mecanismo de adesão dos cimentos autoadesivos é dependente da retenção micromecânica e interação química entre os grupamentos de monômeros ácidos e a hidroxiapatita $(35,42,43)$. Semelhantes aos adesivos autocondicionantes, os cimentos autoadesivos apresentam um baixo $\mathrm{pH}$ quando em contato com a água e umidade do dente (40). A acidez do cimento é suficientemente forte para promover a hibridização com a estrutura dentária. Os monômeros ácidos dissolvem a smear layer, o que permite a penetração do cimento para dentro dos túbulos dentinários, proporcionando a 
formação de uma camada híbrida e boa adesão, além de resultar em retenção micromecânica (37).

O modo de polimerização além de interferir na adesão também pode ter relação com as propriedades mecânicas dos cimentos como microdureza, resistência flexural (44). Sabe-se que os cimentos resinosos autoadesivos são de presa dual e essa característica é essencial uma vez que o restrito acesso de intensidade adequada de luz é situação comum na maioria das restaurações indiretas e cimentação de pinos impedindo a utilização de cimentos apenas fotossensíveis (45); assim nas áreas onde a luz não alcança a reacão ocorre pelo processo de presa químico. A reação dominante de presa ocorre via polimerização do radical livre, iniciada tanto por luz quanto por um sistema redox, que permite a polimerização em um ambiente ácido. Isto resultaria em ligações cruzadas dos monômeros do cimento e a criação de polímeros com alto peso molecular (46).

Os cimentos resinosos autoadesivos parecem apresentar uma nova abordagem promissora para os procedimentos restauradores indiretos (35) e suas aceitações pelos profissionais vêm aumentando (41). De forma geral, apresentam satisfatória biocompatibilidade quando comparados aos cimentos que exigem o condicionamento ácido da superfície $(47,48)$.

Com o intuito de garantir a neutralização do sistema de cimentação previamente ácido, o conceito do ionômero de vidro é aplicado, resultando em aumento do pH de um para seis (35), por meio de reações entre grupos do ácido fosfórico e a carga alcalina de ions de sódio, cálcio, silicato, e flúor. Estes ions podem participar da reação de presa ou serem liberados para o meio $(35,40,41)$. Neste processo de neutralização, ocorreria a formação de água contribuindo com a hidrofilicidade inicial do cimento que melhora a adaptação à estruturação dental e a tolerância à umidade. Subsequentemente, a água é reutilizada pela reação com os grupamentos ácidos funcionais e durante a reação do cimento com os ions liberados das partículas e cargas alcalinas. E dessa, forma, a reação promove uma inteligente mudança resultando numa matriz hidrofóbica com baixa solubilidade, baixa expansão e estabilidade ao longo do tempo $(35,40)$. Vale ressaltar que é desconhecido se a quantidade de água gerada durante a aplicação do 
cimento é suficiente para promover união, ou se a umidade da dentina pode influenciar o mecanismo de união (46).

Os cimentos autoadesivos apresentam presa dual e podem ser indicados para cimentação adesiva de inlays, onlays, coroas e pinos $(35,37)$, independente do material de confecção ser metal, cerâmica ou compósito. O único procedimento no qual o uso desses cimentos não é recomendado é para a cimentação de facetas e lentes de contato, pois é necessário presa exclusivamente fotossensível (35).

A adesão dos cimentos autoadesivos ao esmalte produz uma menor resistência de união do que os cimentos resinosos convencionais (49-52), mas maior do que os cimentos de ionômero de vidro $(50,53)$.

Embora a interface entre os cimentos resinosos convencionais e autoadesivos e a dentina sejam morfologicamente diferentes $(49,54)$, os cimentos autoadesivos tem mostrado uma performance com igual efetividade quando comparado com a maioria dos cimentos resinosos convencionais $(49-51,54,55)$. Porém, os resultados são muito variáveis mostrando-se, em alguns estudos, superiores (56) (57), em outros inferiores em relação aos cimentos resinosos convencionais $(38,58)$. Microscopicamente, observa-se que não ocorre a formação de uma clássica camada híbrida e sim uma mínima interação com o substrato dentinário $(49,54)$.

Conclui-se então que esses cimentos são beneficiados pela adesão química ao dente, baixa solubilidade, mecanismo de autoneutralização durante a reação de presa, alta viscosidade, limitada penetração no substrato e ausência da etapa de condicionamento com ácido fosfórico $37 \%$. Essas características correlacionam-se também com a sensibilidade pós-operatória que é baixa ou ausente com os autoadesivos. A sensibilidade pós-operatória do dente está associada com o processo de cimentação desde a introdução do cimento de fosfato de zinco e aumentou com o uso dos cimentos resinosos combinados com sistemas adesivos convencionais (59), porém de acordo com estudos clínicos $(60,61)$ vem se observando um declínio nos relatos de sensibilidade pós-operatória quando são empregados os cimentos autoadesivos para a cimentação de restaurações indiretas. 


\subsection{ENSAIOS LABORATORIAIS PARA DETERMINAÇÃO DA RESISTÊNCIA DE UNIÃO ADESIVA}

A realização de um método de teste padrão validado amplamente aceito para testes de resistência de união de adesivos resinosos dentários é um esforço indescritível e controverso (62) (63). Embora um consenso ou procedimento padrão não exista atualmente, testes de resistência de união permanecem úteis e necessários para pesquisas de novos produtos e estudos de variáveis experimentais (64).

Durante muitos anos, procurou-se desenvolver testes mecânicos que pudessem reproduzir in vitro os fenômenos sofridos pelos materiais restauradores na cavidade bucal. Até meados da década de 1990 foram largamente utilizados os teste de tração e cisalhamento para mensurar a resistência de adesão entre substrato e materiais restauradores (65).

Ensaios de resistência de união tradicionais são, em geral, realizados por meio da confecção de apenas um espécime por dente ou superfície desgastada de um elemento dental, que é então carregado até a falha em uma configuração de ensaio de cisalhamento, de tração ou outro modo de carregamento menos tradicional (64).

A escolha desses testes ocorria pela facilidade de realização, já que poucos equipamentos eram necessários e não havia uma preocupação efetiva com o preparo das amostras, com relação ao tipo de substrato, tipo de compósito, distribuição de cargas e a sua geometria (65). Porém, a resistência nominal ou áreas obtida pelos testes de tração e cisalhamento pode variar de acordo com essas características, principalmente com relação à diferenças na distribuição de cargas, tornando as mensurações bastante questionáveis (66).

Além disso, nestes ensaios caracterizados como "macro", as falhas coesivas tanto de substrato dental quanto de compósito restaurador são relativamente comuns, impossibilitando uma avaliação precisa da resistência de união da interface adesiva (67). 
Para superar esses inconvenientes foram sugeridos testes em que a área de adesão fosse diminuída. Pois há uma tendência de se encontrarem maiores valores de resistência de união em áreas de adesão menores. Isso acontece porque em áreas de superficies maiores haveria maior chance de se introduzir defeitos maiores entre substrato e material restaurador, diminuindo assim a resistência de união. Surgiram então os testes de microtração e microcisalhamento, nos quais podem ser encontrados maiores valores de resistência de união do que nos seus antecessores.

$\mathrm{Na}$ Odontologia, o teste de microtração foi descrito pela primeira vez por Sano et al., 1994. Os corpos de prova submetidos ao teste de microtração devem ser conformados em formatos diferentes, incluindo a forma de ampulheta, halteres e palitos e a geometria das amostras é de grande relevância na homogeneidade da distribuição de tensões a que estes espécimes estão sendo submetidos (64).

Logo depois da sua introdução na literatura odontológica, os ensaios de microtração começaram a ser extensamente utilizados para a determinação de resistência de união adesiva, já que eles apresentam muitas vantagens: o tamanho pequeno dos espécimes utilizados promove uma melhor avaliação da distribuição de tensões na interface adesivo/dentina; um menor número de falhas coesivas e um maior número de falhas adesivas é relatado; o ensaio permite a determinação da resistência de união em diferentes regiões da dentina em um mesmo dente, sendo assim médias e variâncias podem ser calculadas para cada elemento dental; o ensaio permite análises de superficies irregulares e verificar a resistência de união de áreas muito pequenas; e maior facilidade na análise de superfícies sob microscopia eletrônica de varredura (68, $69,70)$.

Entretanto, apesar do grande número de vantagens, o teste de microtração também apresenta desvantagens, entre elas, a dificuldade de confecção dos espécimes e a possibilidade da inserção de defeitos superficiais durante a usinagem dos espécimes, a elevada exigência técnica, potencial de desidratação destas amostras menores, a possibilidade de danos à superfície de fratura quando da remoção dos espécimes do suporte prejudicando a análise de falhas e a falta de consenso sobre como reportar as falhas pré-teste $(67,69)$. 
Testes de resistência de união ao cisalhamento com área em corte transversal de $1 \mathrm{~mm}^{2}$ ou menos é também referido como 'micro' SBS (71). Descrito inicialmente por Shimada et al., 2002 (72), o ensaio de microcisalhamento tornou-se mais popular por ser uma alternativa para o teste de cisalhamento convencional (73). Quando comparado ao teste de cisalhamento, o teste de microcisalhamento parece apresentar uma distribuição do estresse mais concentrada na interface (74), reduzindo a chance de falhas coesivas em material ou substrato, falhas estas que não representam valores "reais" de resistência adesiva do material, pois nesses casos não se atinge a interface adesiva (75). Além disso, no ensaio de microcisalhamento também é possível a obtenção de vários espécimes por dente, dado que com a delimitação da área adesiva, cada um recebe um procedimento adesivo independente do outro, sem, todavia, a ocorrência de danos provenientes do corte da amostra, como acontece nos ensaios de microtração (64).

Desde que o teste de união ao microcisalhamento foi introduzido, o tubo de tygon tem sido recomendado para confecção dos espécimes de compósitos resinosos (72) e a maioria dos estudos que utilizam-se desta metodologia, fazem uso desse tipo de tubo $(5,7,65,76-78)$. Todavia, Tedesco et al. 2013 avaliaram o efeito de um tubo alternativo de amido na confecção dos espécimes e demonstraram que os valores de resistência de união não foram afetados pelo tipo de tubo utilizado. Os autores relataram maior facilidade de inserção do material no tubo, devido, provavelmente, à sua composição, que é um material inativo que não promove nenhuma reação com sistemas adesivos ou resinas compostas (79). Além disso, pontuaram algumas vantagens do uso deste tubo comparado ao de polietileno (tygon), dentre elas, além da facilidade de inserção do material, estão: facilidade de remoção do tubo, evitando que falhas pré-teste, como as relatadas para o de tygon, ocorram e maior sorção de água pelo material resinoso, o que aproximaria às condições in vivo (79). Similarmente à vantagem relatada ao uso do tubo de polietilieno, o tubo de amido apresenta um diametro interno reduzido, padronizado com baixo desvio padrão, confeccionando cilindros com áreas transversais menores que $1 \mathrm{~mm}^{2}$, o que o levaria a ser considerado como teste de resistência de união "micro". 
Devido à ausência da necessidade de desgastes mais elaborados, esse ensaio apresenta-se mais vantajoso para a análise do esmalte dental e melhor indicado para materiais como ionômero de vidro, e materiais friáveis. Outra vantagem é o fato da possibilidade de utilizar várias regiões do mesmo elemento dentário, tornando o método mais simples e mais rápido. Além disso, também é possível o mapeamento regional de diferentes áreas de dentina, a investigação da longevidade da resistência de união in vitro e a elucidação dos mecanismos de adesão $(64,74,78)$. 


\section{OBJETIVOS}

\subsection{OBJETIVO GERAL}

Avaliar o efeito de protocolos de limpezas sobre a resistência de união ao microcisalhamento de um cimento resinoso autoadesivo à dentina contaminada com diferentes agentes de efeito hemostático.

\subsection{OBJETIVOS ESPECÍFICOS}

- Comparar a resistência de união ao microcisalhamento obtida entre os grupos de contaminantes e controle.

- Comparar a resitência de união ao microcisalhamento obtida para os grupos de agentes hemostáticos convencionais (ViscoStat e ViscoStat Clear) e para os agentes de possibilidade de inserção na Odontologia (Visine e Sure)

- Analisar a eficácia e desempenho dos protocolos de limpeza frente aos diferentes contaminantes.

- Verificar se alguns protocolos de limpeza possuem interação favorável com alguns agentes hemostáticos, em relação à resistência de união adesiva, mas desfavorável a outros.

- Verificar possíveis relações entre o material cimentante selecionado e ação do agente contaminante e/ou protocolo de limpeza utilizado. 
Para isto, as seguintes hipóteses nulas foram testadas:

1. não há diferença nos valores de resistência de união ao microcisalhamento entre os diferentes agentes hemostáticos utilizados;

2. não há diferença nos valores de resistência de união ao microcisalhamento entre os diferentes protocolos de limpezas;

3. não há diferença nos valores de resistência de união ao microcisalhamento entre as diversas combinações obtidas entre os diferentes protocolos de limpeza e agentes contaminantes utilizados. 


\section{MATERIAIS E MÉTODOS}

\subsection{PREPARO DOS DENTES}

Foram utilizados 105 incisivos inferiores permanentes bovinos, dentro de um período de 3 meses após a extração, devidamente limpos e armazenados em solução neutra de timol a $0,1 \%$ a $6^{\circ} \mathrm{C}$, para prevenir desidratação e crescimento bacteriano. Os dentes foram aleatoriamente divididos em 21 grupos experimentais $(n=5)$. O esmalte da face vestibular foi desgastado em recortador de gesso (VRC, VRC Equip., Guarulhos, São Paulo), sob refrigeração, para expor a superfície dentinária. Essa superfície foi desgastada até que toda a porção de esmalte fosse removida e a dentina mais superficial exposta. Em seguida, para planificação da superfície, utilizou-se lixas de carbeto de silício $\mathrm{n}^{\circ} 320$.

As porções radiculares foram removidas com auxílio de disco diamantado dupla face (KG Sorensen, Cotia, SP, Brasil) montado em peça reta. Para tornar viável o estudo da adesão à dentina, os dentes foram incluídos em cilindros de polietileno, diâmetro de 32mm (Bucha de redução soldável, Tigre, Joinville, SC, Brasil), previamente isolados com vaselina sólida. $O$ acesso à câmara pulpar foi bloqueado por meio de cera rosa $n^{\circ} 7$ (Lysanda, JB Med e Odonto Products, SP,São Paulo), para impedir que escoasse resina acrílica no momento da inclusão. As coroas foram fixadas em fita auto-adesiva, com as superfícies dentinárias expostas direcionadas para baixo, e os cilindros posicionados de forma a deixar a coroa centralizada. Os cilindros foram preenchidos com resina acrílica incolor autopolimerizável (Jet Clássico, São Paulo, SP, Brasil) na proporção 1:1. Os cilindros utilizados foram removidos após a polimerização da resina acrílica e armazenados em água destilada a $6^{\circ} \mathrm{C}$. 


\subsection{DELINEAMENTO EXPERIMENTAL}

Neste estudo a variável de resposta, resistência de união adesiva, foi avaliada quantitativamente por meio do ensaio mecânico de microcisalhamento. Os fatores de variação foram: agente de contaminação, em 4 níveis (Viscostat gel - Sulfato de Ferro, Viscostat Clear gel - Cloreto de Alumínio, Visine - Tetrahidrozolina, Sure Triclorohidrex de alumino zircônio); e o material de limpeza utilizado, em 5 níveis (Água, Ácido fosfórico, Ácido Etilenodiaminotetracético trissódico, Óxido de Alunínio, Dióxido de Silício). Formou-se portanto 21 grupos experimentais. Vinte obtiveram tratamento de superfície pelas diversas associações entre contaminante e limpeza, e um, separado para controle, não obteve nenhum tipo de contaminação, nem subsquente protocolo de limpeza. As marcas comerciais dos materais empregados neste estudo e suas características estão apresentadas na Tabela 2.

Tabela 2 - Materiais utilizados no estudo.

\begin{tabular}{|c|c|c|}
\hline NOME COMERCIAL & FABRICANTE & COMPOSIÇÃO \\
\hline RelyX U200 & $\begin{array}{l}3 \mathrm{M} \quad \text { Dental } \\
\text { Products, } \quad \text { ST. } \\
\text { Paul, MN, USA. }\end{array}$ & $\begin{array}{l}\text { Tubo contendo pasta base e pasta } \\
\text { catalisadora com sistema clicker. } \\
\text { Fibra de vidro, ésteres ácido fosfórico } \\
\text { metacrilato, grupos bifuncionais de } \\
\text { metacrilato, sílica tratada com silano, } \\
\text { persulfato de sódio e hidróxido de } \\
\text { cálcio. }\end{array}$ \\
\hline ViscoStat (V) & $\begin{array}{l}\text { Ultradent Products } \\
\text { Inc., South Jordan, } \\
\text { UT. }\end{array}$ & $\begin{array}{l}\text { Seringa contendo gel de } 20 \% \\
\mathrm{Fe}_{2}\left(\mathrm{SO}_{4}\right)_{3} \text {. }\end{array}$ \\
\hline ViscoStat Clear (VC) & $\begin{array}{l}\text { Ultradent Products } \\
\text { Inc., South Jordan, } \\
\text { UT. }\end{array}$ & Seringa contendo gel de $20 \% \mathrm{AlCl}_{3}$. \\
\hline Visine Original (E) & $\begin{array}{l}\text { McNeil-PPC, } \\
\text { Lancaster, Pa. }\end{array}$ & Tetrahidrozolina $\mathrm{HCl}$ 0,05\% \\
\hline
\end{tabular}


Conclusão Tabela 2.

\begin{tabular}{|c|c|c|}
\hline NOME COMERCIAL & FABRICANTE & COMPOSIÇÃO \\
\hline Sure (D) & $\begin{array}{l}\text { Idelle Labs, Ltda., } \\
\text { El Paso, Canada }\end{array}$ & $\begin{array}{l}\text { Triclorohidrex de alumino zirconio } \\
\text { GLY } 19 \%\end{array}$ \\
\hline Alpha Etch Gel (A) & $\begin{array}{l}\text { Nova DFL Ind. E } \\
\text { Com. S.A }\end{array}$ & Ácido fosfórico 37\% \\
\hline \multirow[t]{2}{*}{ E.D.T.A Gel (E) } & Biodinâmica & Ácido etilenodiaminotetracético \\
\hline & $\begin{array}{l}\text { Quím. E Farm. } \\
\text { Lda., Ibiporã, } \\
\text { PR,Brasil }\end{array}$ & $\begin{array}{l}\text { Dissódico, Hidróxido de Sódio, Água } \\
\text { Deionizada e Espessante }\end{array}$ \\
\hline Pedra-Pomes (P) & $\begin{array}{l}\text { Polidental Ind. } \\
\text { Com. Ltda., Cotia, } \\
\text { SP, Brasil }\end{array}$ & Quartzo \\
\hline 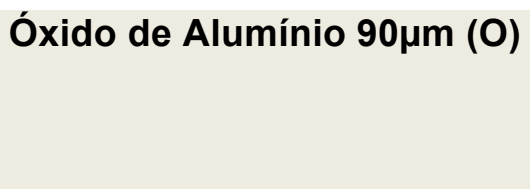 & $\begin{array}{lr}\text { Bio-art } & \text { Equip. } \\
\text { Odontol, } & \text { São } \\
\text { Carlos, } & \text { SP, } \\
\text { Brasil }\end{array}$ & $\begin{array}{l}\text { Partículas de Óxido de Alumínio } 90 \\
\mu \mathrm{m}\end{array}$ \\
\hline
\end{tabular}

\subsection{CONFECÇÃO DOS CORPOS DE PROVA}

Previamente ao tratamento das superficies dentinárias, foi realizada profilaxia com escova de Robinson e pasta à base de pedra-pomes e água, em todos os grupos experimentais. A padronização da smear layer foi obtida com o auxílio de lixa d'água de carbeto de silício de granulação 600 (Norton, São Paulo, Brasil), durante 60 segundos. Esse acabamento foi feito manualmente, realizando-se movimentos em forma de oito (Figura 2), visto que a força aplicada para esse movimento é melhor distribuída do que quando o espécime é mantido manualmente em máquina lixadeira ou em movimentos de vai e vem. 


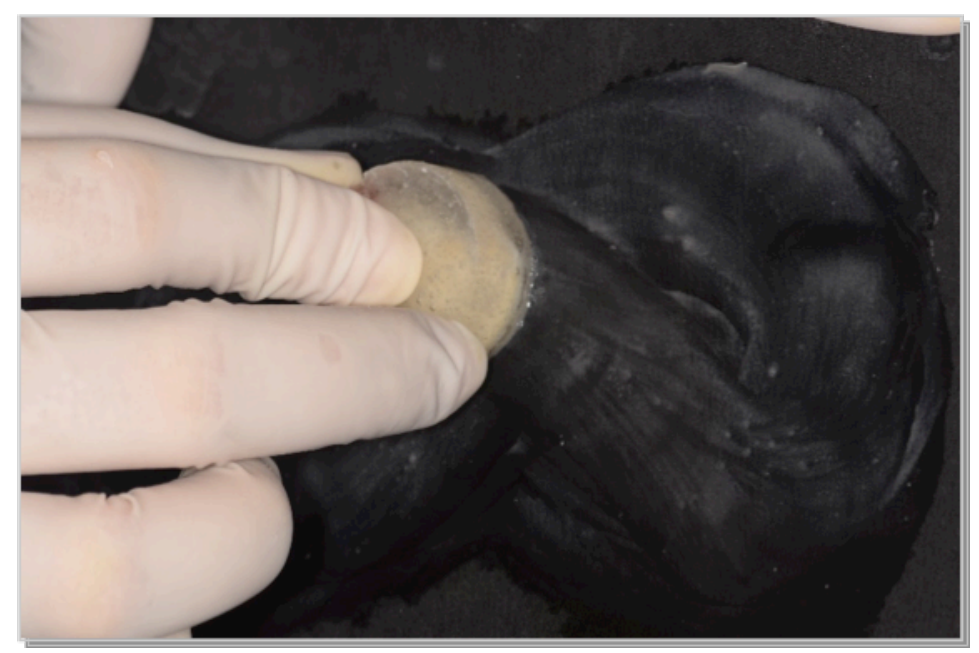

Figura 2. Padronização da smear layer, movimento em 8.

Após a obtenção da camada de esfregaço padrão, um jato de spray de água era direcionado por 30 segundos sobre a superfície dentinária, que era então seca com jato de ar por 10 segundos a uma distância de aproximadamente 10 centímetros. Seguia-se então os protocolos de contaminação e limpeza para confecção dos grupos.

Inicialmente, os dentes foram dividivos aleatoriamente em 4 grupos $(n=25)$ de acordo com o agente contaminante:

GRUPO V (ViscoStat) - Aplicação com a seringa do gel hemostático de $20 \%$ $\mathrm{Fe}_{2}\left(\mathrm{SO}_{4}\right)_{3}$. Tempo de contaminação: 2 minutos (Figura 3).
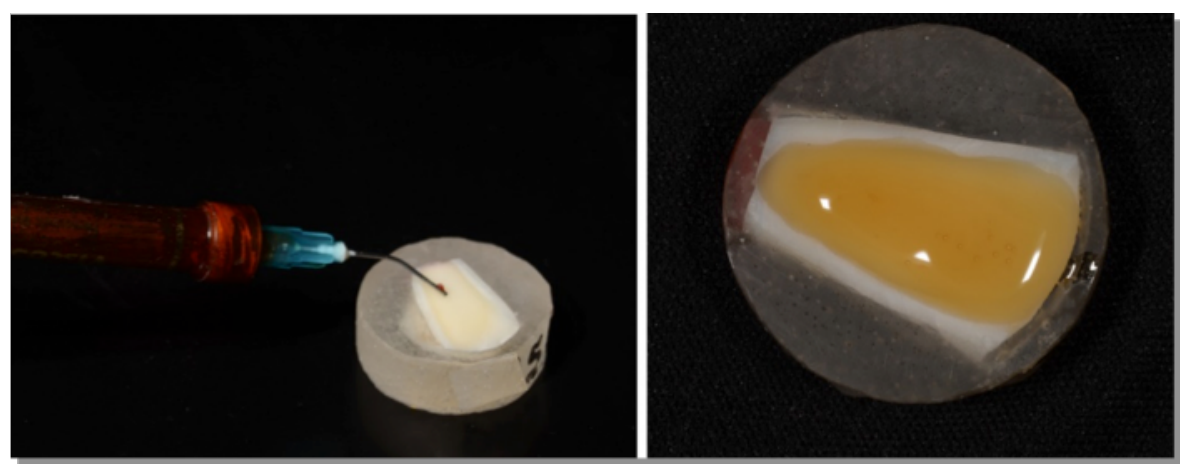

Figura 3 - Contaminação com ViscoStat. 
GRUPO VC (ViscoStat Clear) - Aplicação com a seringa do gel hemostático de $20 \% \mathrm{AlCl}_{3}$. Tempo de contaminação: 2 minutos (Figura 4).
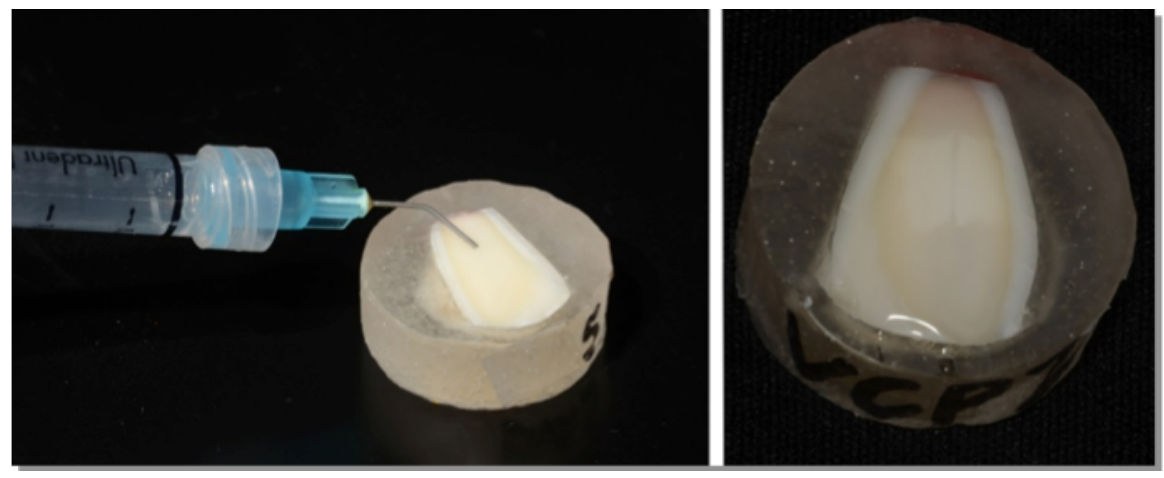

Figura 4 - Contaminação com ViscoStat Clear.

GRUPO E (Visine) - Duas gotas foram vertidas sobre a superfície dentinária de forma a cobrí-la por inteiro. Tempo de contaminação: 2 minutos (Figura 5).

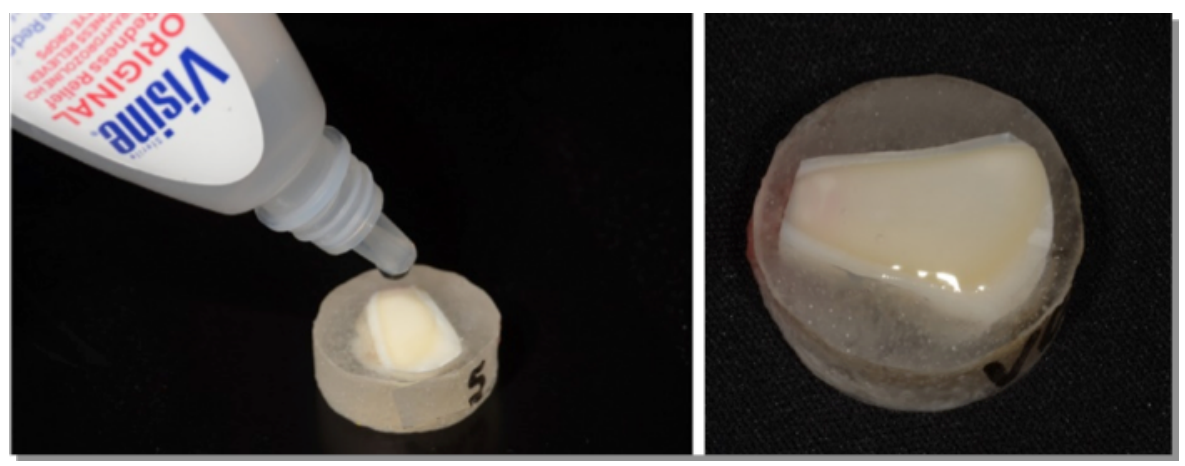

Figura 5 - Contaminação com colírio Visine.

GRUPO D (Sure) - Com o auxílio de uma espátula n 24 (Golgran, São Paulo, $\mathrm{SP}$, Brasil) uma quantidade do produto era coletada (Figura 6A) e então manipulada em uma placa de vidro (Figura 6B) para melhorar sua viscosidade. Com a mesma espátula 
o desodorante era prensado sobre a superfície dentinária (Figura 6C). Tempo de contaminação: 2 minutos (Figura 6D).

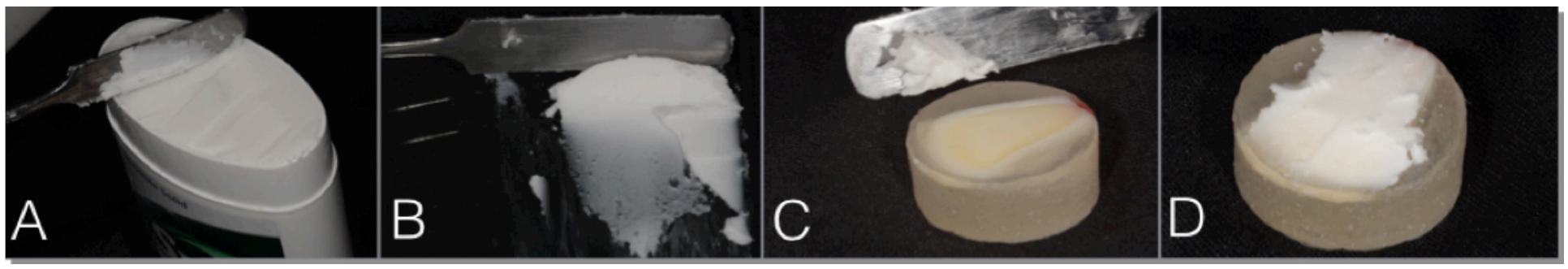

Figura 6 - Procedimentos para contaminação do grupo D. A - Coleta da pasta do desodorante. B - Manipulação em placa de vidro com espátula n²4. C - Aplicação do produto sobre a dentina. D - Espera do tempo de contaminação por 2 minutos.

Após contaminados, todos os dentes recebiam um vigoroso jato de ar para remoção do excesso das substâncias e eram então divididos em 5 subgrupos $(n=5)$ conforme o protocolo de limpeza:

SUBGRUPO W (Água) - Um jato spray de água era direcionado contra à superfície contaminada por 15 segundos (Figura 7).

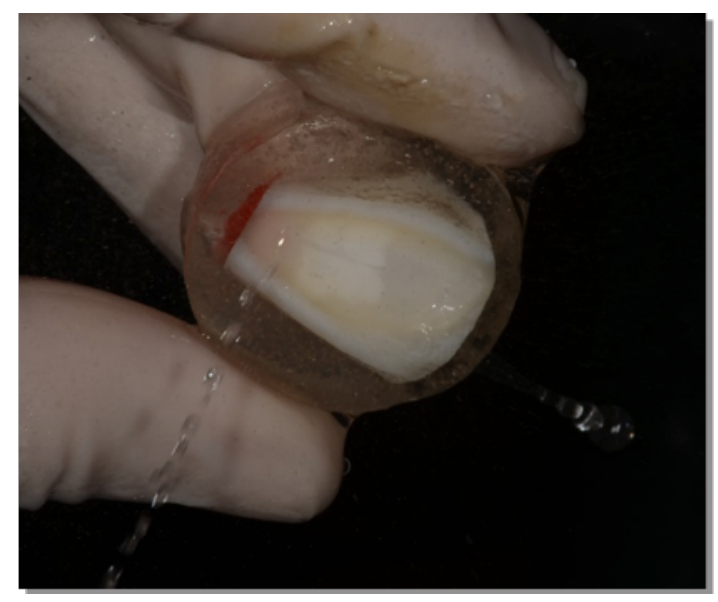

Figura 7 - Jato spray de água por 15 segundos. 
SUBGRUPO A (Ácido fosfórico) - Ácido fosfórico era aplicado sobre a superfície por 15 segundos e então removido com jato spray de água por 15 segundos (Figura 8).
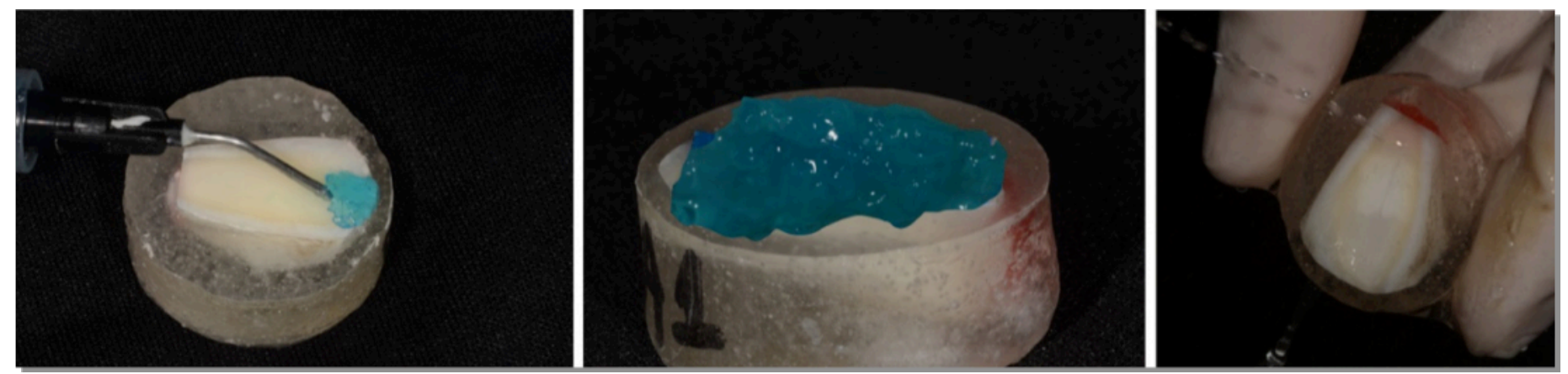

Figura 8 - Procedimentos para limpeza com Ácido fosfórico 37\%.

SUBGRUPO E (EDTA) - Ácido etilenoaminotetraacético (EDTA) era aplicado sobre a superfície por 60 segundos e então removido com jato spray de água por 15 segundos (Figura 9).
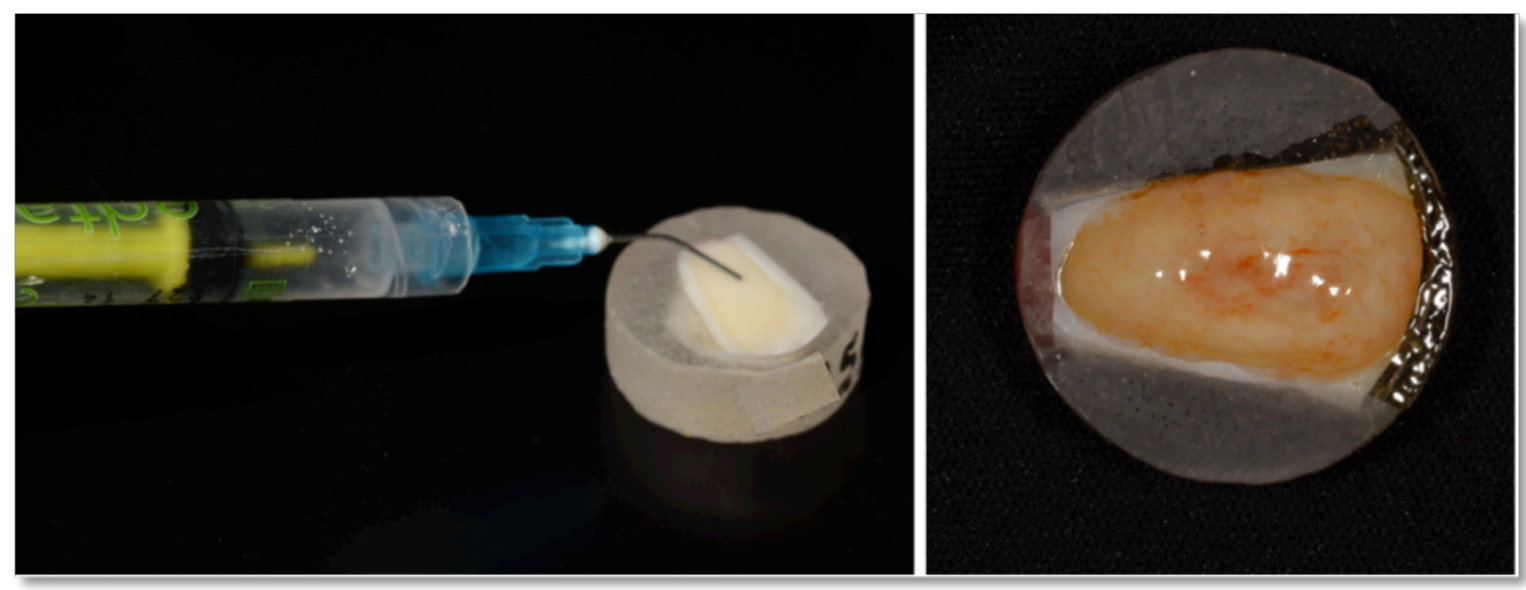

Figura 9 - Procedimentos para limpeza com EDTA. Devido sua ligação com ferro, uma visível reação química pode ser observado para o grupo ViscoStat. 
SUBGRUPO O (Óxido de Alumínio) - A superfície contaminada era jateada com partículas de óxido de alumínio de $90 \mu \mathrm{m}$ a 50 psi por 15 segundos à $2 \mathrm{~mm}$ de distância da superfície e então lavada com jato spray de água por 15 segundos (Figura 10).

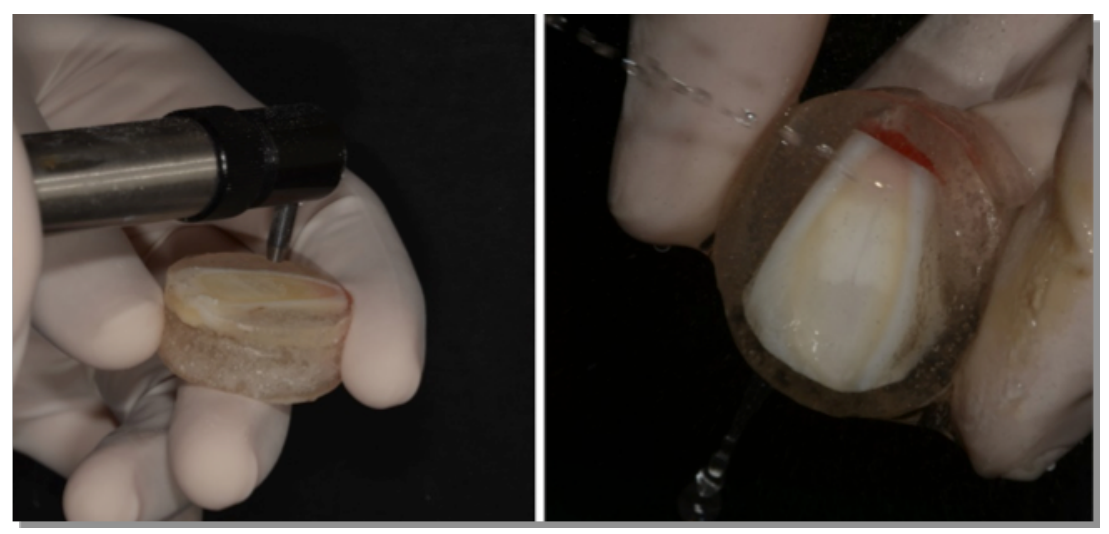

Figura 10 - Procedimentos para limpeza com óxido de alumínio $90 \mu \mathrm{m}$.

SUBGRUPO P (Pedra-pomes) - Uma pasta à base de pedra-pomes e água era aplicada na superfície com uma escova de Robinson em contra-ângulo em baixarotação por 15 segundos e então lavada com jato de água por 15 segundos (Figura 11).

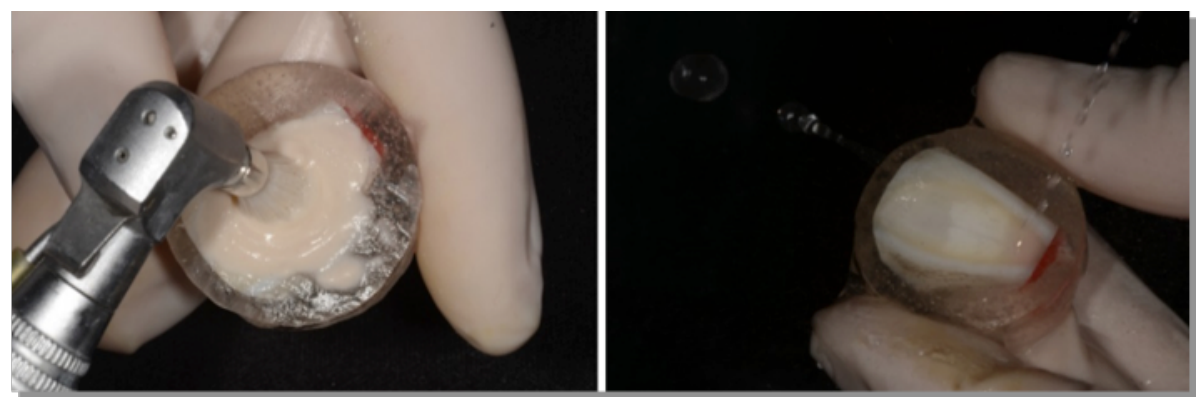

Figura 11 - Procedimentos para limpeza com Pedra-pomes.

Assim sendo, ao final, 21 grupos experimentais foram obtidos. Vinte contaminados, conforme Tabela 3, e um GRUPO CONTROLE (C) para o qual não foi utilizado nenhum tipo de contaminação, nem limpeza, os procedimentos adesivos foram 
feitos imediatamente após a padronizaçaõ da smear layer. A princípio cada grupo foi composto por 5 dentes, sobre os quais no mínimo 4 espécimes de resina era possível confeccionar. Todavia, após a realização do ensaio mecânico, para os grupos que apresentaram desvio padrão mais elevado e/ou considerável número de valores de resistência igual a zero, foi acrescentado mais dentes e confeccionados mais espécimes.

Portanto, o número de espécimes dentro de cada grupo é variável, o que não possui influência, entretanto, sobre os valores de média e resultados dos grupos, mas ao contrário, favoreceu a homogeneidade intra-grupo.

Tabela 3. Grupos experimentais contaminados.

\begin{tabular}{|c|c|c|c|c|c|}
\hline LIMPEZA & $\begin{array}{l}\text { Água } \\
\text { (W) }\end{array}$ & $\begin{array}{l}\text { Ácido } \\
\text { Fosfórico } \\
\text { (A) }\end{array}$ & EDTA & $\begin{array}{l}\text { Óxido de } \\
\text { Alumínio } \\
\text { (0) }\end{array}$ & $\begin{array}{l}\text { Pedra- } \\
\text { Pomes } \\
\text { (P) }\end{array}$ \\
\hline ViscoStat (V) & VW & VA & VE & VO & VP \\
\hline ViscoStat Clear (VC) & VCW & VCA & VCE & VCO & VCP \\
\hline Visine (E) & EW & EA & EE & EO & EP \\
\hline Sure (D) & DW & DA & $\mathrm{DE}$ & DO & DP \\
\hline
\end{tabular}

Após o tratamento da superfície, previamente aos procedimentos de confecção dos cilindros resinosos, a dentina foi seca com um jato de ar por 10 segundos, à uma distância de $8 \mathrm{~cm}$, permanecendo ainda levemente úmida.

Com perfurador de dique de borracha, uma fita auto-adesiva dupla-face foi perfurada, confeccionando-se 5 orifícios ( $n^{\circ} 2$ ) (Figura 12). Com o auxílio de uma pinça a fita era posicionada sobre a dentina para delimitação da área de adesão (Figura 13A) e fixação dos tubos de amido (Renata, Pastifício Selmi, Londrina, PR, Brasil) (79) de proporções $0,96 \mathrm{~mm}$ de diâmetro interno e $2 \mathrm{~mm}$ de altura. Com uma pinça os tubos eram posicionados sobre o oríficio da fita colada à superfície dentinária já tratada (Figura 13B e 13C). Uma leve pressão sobre o tubo era exercida para assegurar sua fixação e imobilidade. 


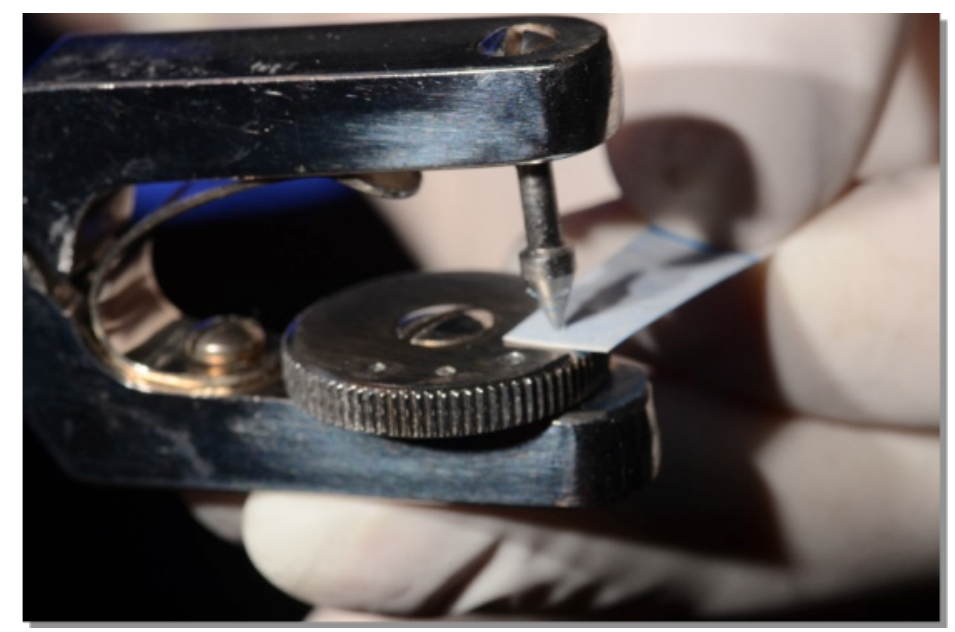

Figura 12 - Perfuração da fita auto-adesiva dupla face.

O cimento RelyX U200 (3M Dental Products, ST. Paul, MN, EUA) era então dispensado no bloco de manipulação fornecido pelo fabricante, e espatulado com o auxílio de uma espátula $n^{\circ} 24$ (Golgran, São Paulo, SP, Brasil) conforme instruções do fabricante. Com um brunidor no 33 (Golgran, São Paulo, SP, Brasil) o cimento era inserido dentro do tubo (Figura 13D). O excesso de cimento era removido com a ajuda de um microbrush (Cavibrush, FGM, Joinville, SC, Brasil) (Figura 13E) e então realizava-se a fotopolimerização por 20 segundos (Figura 13F). Todos os procedimentos de foto ativação foram realizados com um aparelho LED com $1000 \mathrm{~mW} / \mathrm{cm}^{2}$ de intensidade de luz (Bluephase G2, Ivoclar, Vivadent).

Após confecção dos cilindros resinosos, os espécimes eram armazenados em recipiente plástico fechado com $100 \%$ de umidade em água destilada e acondicionados em estufa (ECB 1.3 Digital, Ind. e Com. Equip. Med. Odont. LTDA) à $37^{\circ} \mathrm{C}$ por $24 \mathrm{~h}$. 

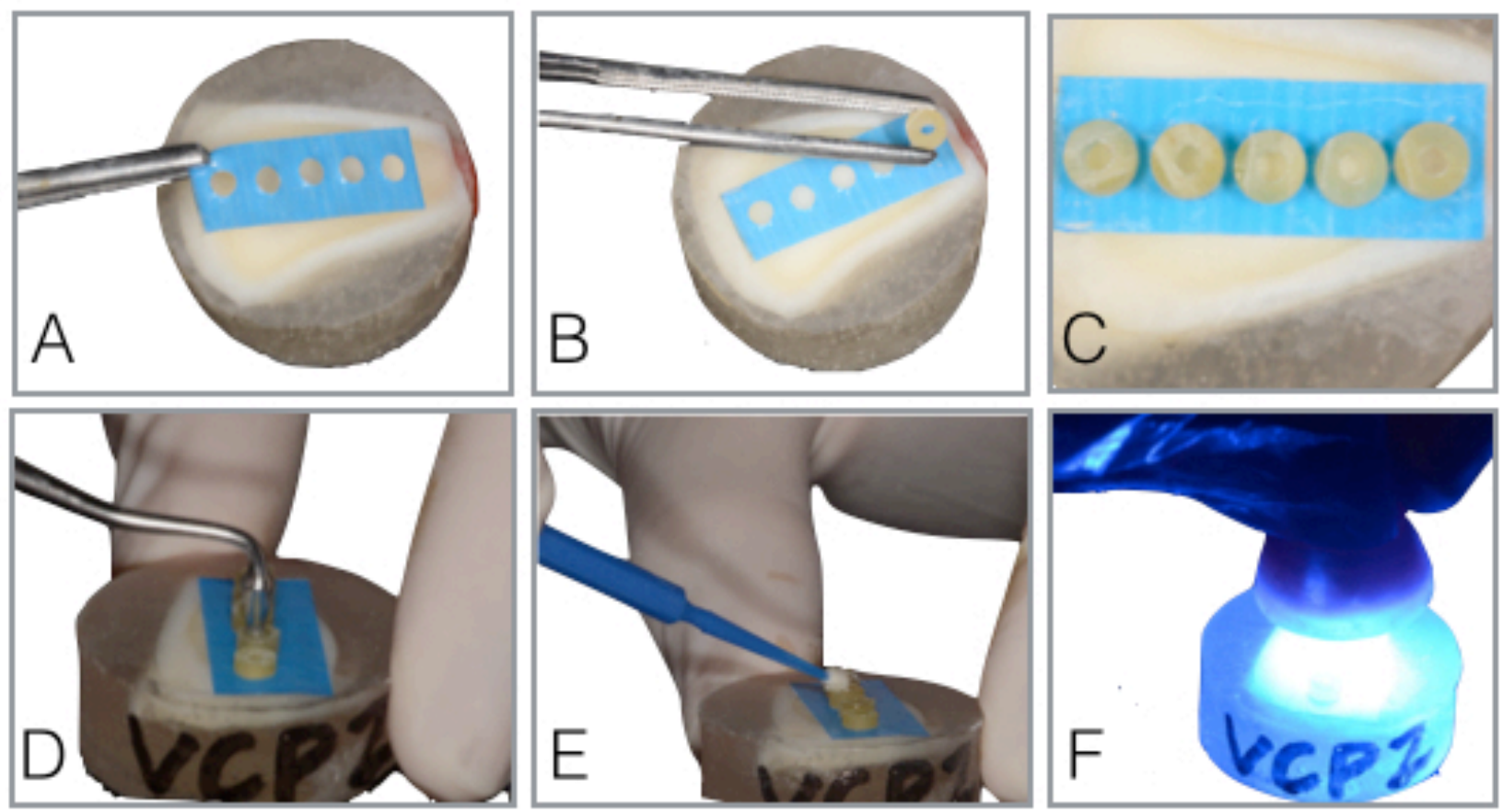

Figura 13. Sequência de confecção dos cilindros de cimento auto-adesivo RelyX U200. A- Posicionamento da fita auto-adesiva dupla-face sobre a dentina tratada, B- Fixação dos tubos de amido sobre a fita. C- Concordância do orifício da fita e diâmetro interno do tubo. DInserção do cimento resinoso com auxílio de brunidor. E- Remoção de excesso de cimento com microbrush. F- Fotopolimerização por 20 segundos.

\subsection{RESISTÊNCIA DE UNIÃO AO MICROCISALHAMENTO}

Decorridas 24 horas da confecção dos espécimes, com o auxílio de uma lâmina de bisturi $\mathrm{n}^{0} 15$ o tubo de amido era facilmente removido (Figura 14), e a fita adesiva dupla-face cortada e retirada. 

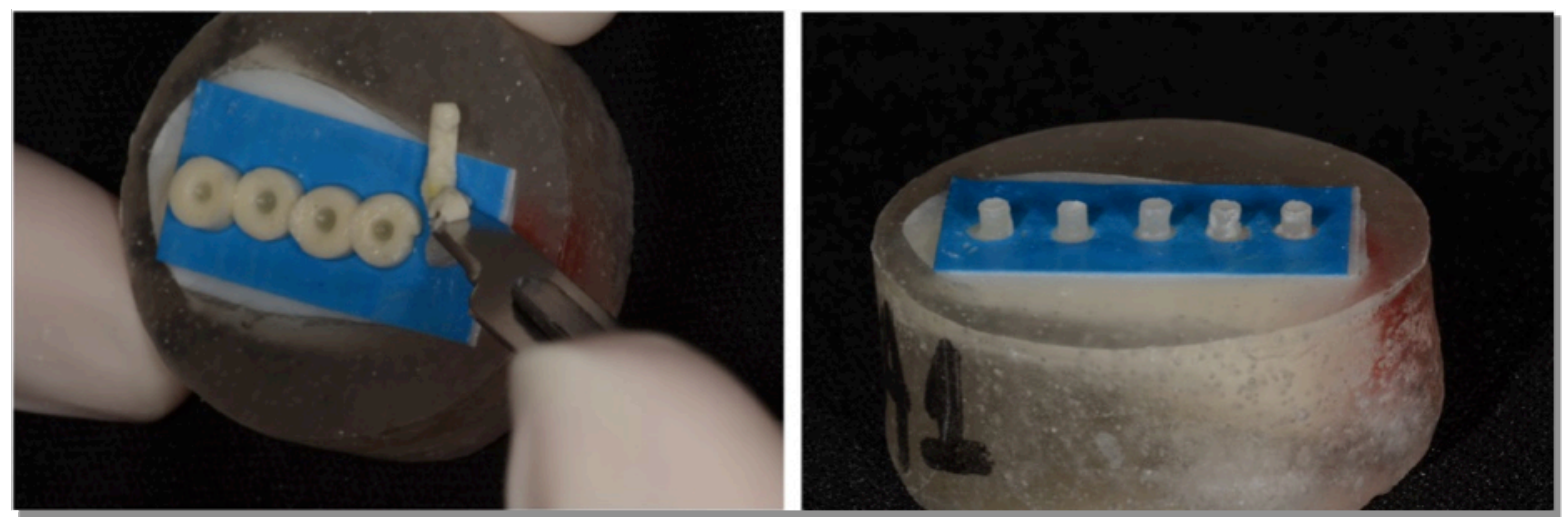

Figura 14 - Remoção do tubo de amido após 24 horas.

Para realização do teste de resistência de união ao microcisalhamento (RUMC), cada corpo de prova foi colocado, individualmente, em um suporte metálico contendo um orifício. Esse suporte possui dois parafusos utilizados para ajustar o cilindro de resina acrílica de maneira que ele fique imobilizado (Figura 15).

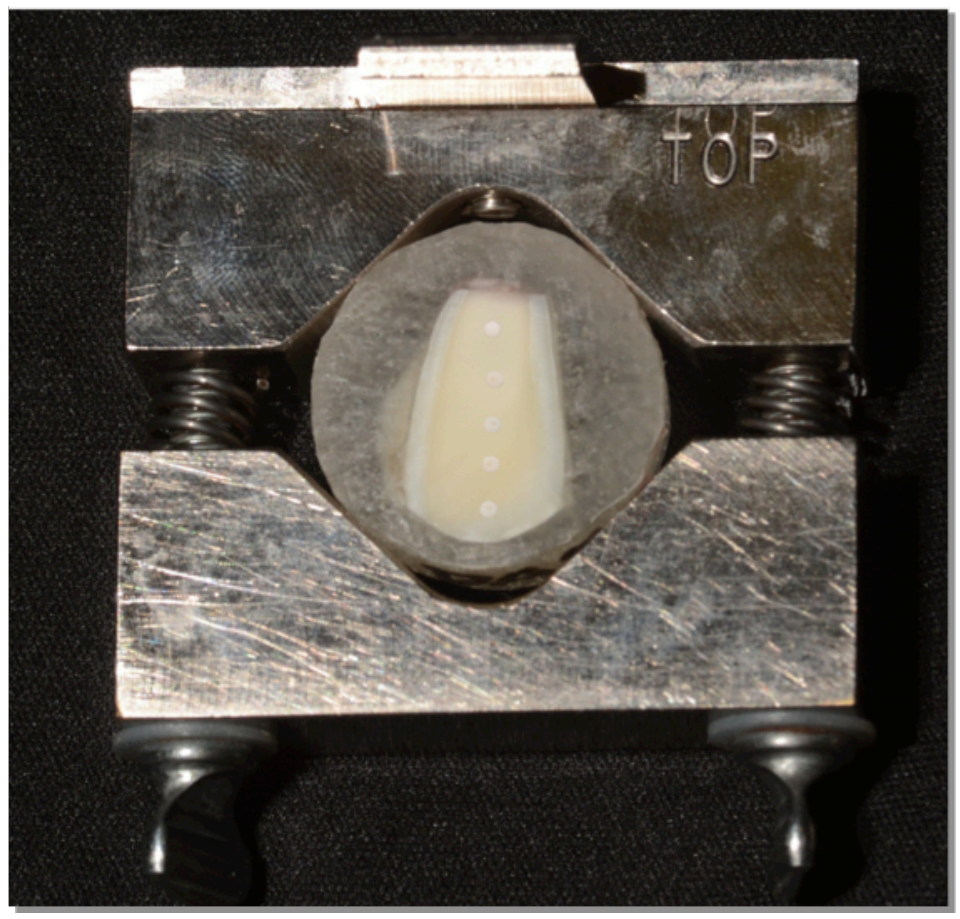

Figura 15 - Suporte metálico para imobilização do cilindro de resina acrílica e posterior encaixe na máquina de cisalhamento. 
Cada conjunto formado por suporte metálico e corpo-de-prova foi levado à máquina de ensaios mecânicos de resistência ao cisalhamento (Bisco Shear Bond Tester, Bisco, EUA) (Figura 16) onde uma carga, por intermédio de uma ponta ativa em forma de cinzel (Figura 17), foi aplicada na região da interface adesiva, paralelamente à superfície dental. A máquina Bisco Shear Bond Tester é uma máquina para testes de resistência ao cisalhamento, sua ponta ativa é em forma de semi-círculo para cilindros de área transversal de $3 \mathrm{~mm}^{2}$. Para possibilitar a execução do teste de microcisalhamento, a máquina foi adaptada com uma nova peça fabricada em forma de cinzel (Figura 18). A máquina foi programada para operar com uma célula de carga de 50 kiloNewton $(\mathrm{kN})$ a uma velocidade de $0,5 \mathrm{~mm} /$ minuto. Os valores registrados em Newtons $(\mathrm{N})$ foram posteriormente relacionados à área de adesão, para cálculo da resistência de união (MPa).

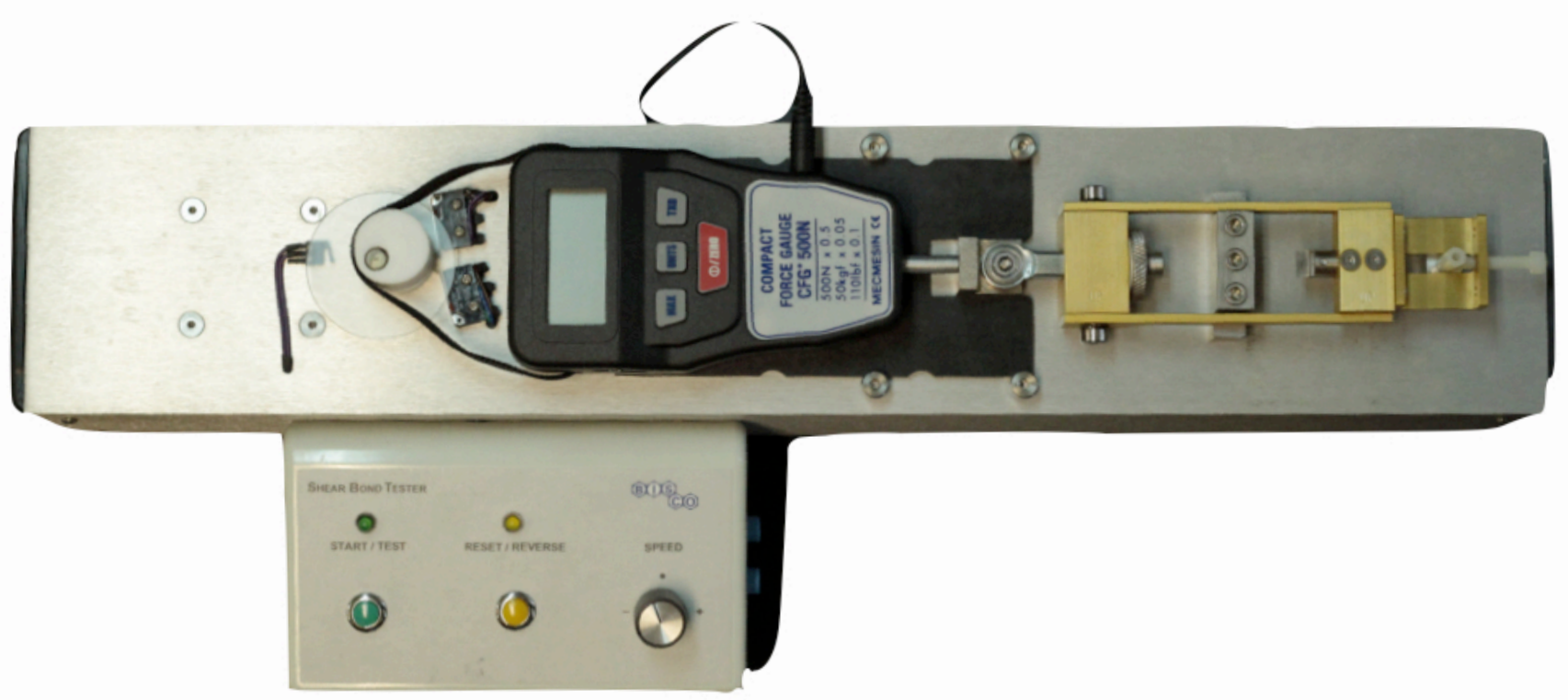

Figura 16 - Máquina Bisco Shear Bond Tester. 


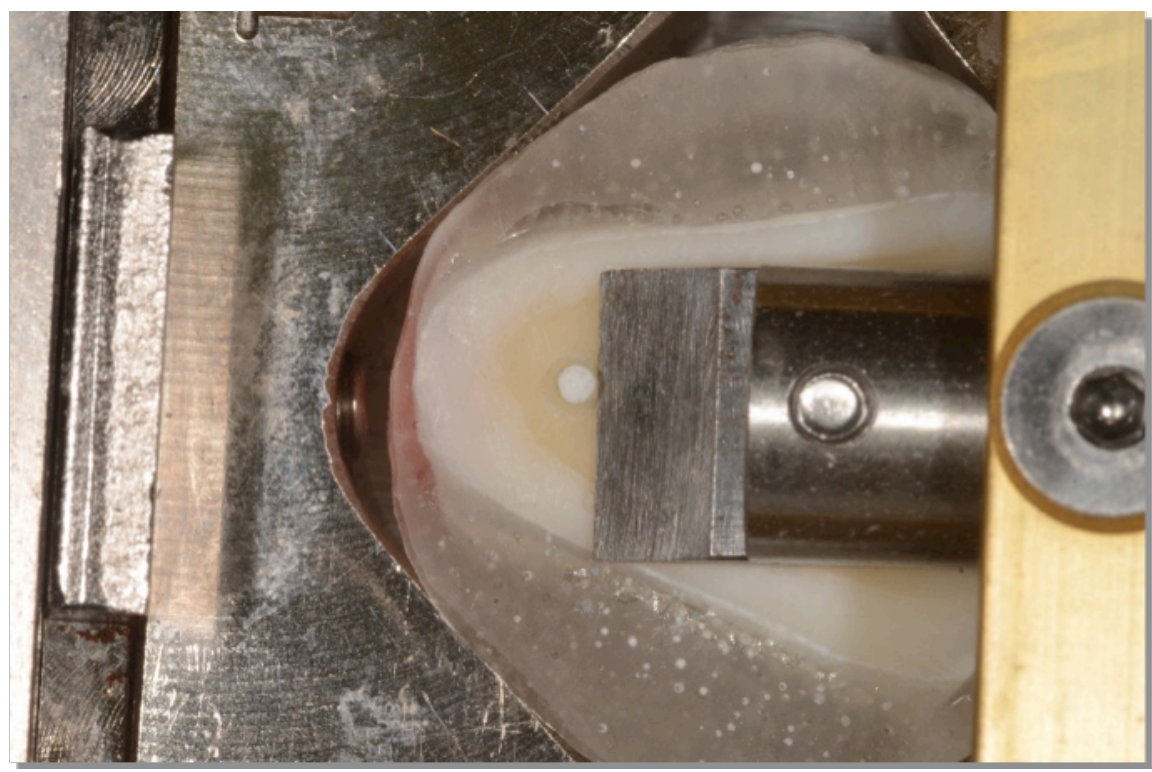

Figura 17 - Ponta ativa em forma de cinzel em justaposição à superfície dentinária, paralelamente à interface adesiva.

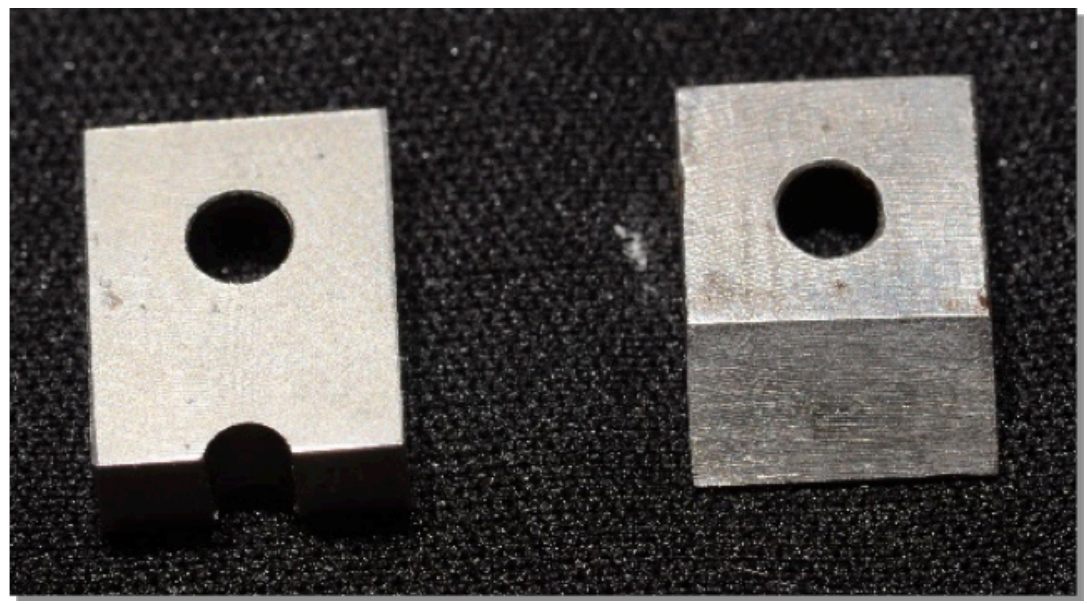

Figura 18 - À esquerda, ponta ativa em semi-círculo para cisalhamento. À direita, ponta ativa fabricada em forma de cinzel para micro-cisalhamento. 


\subsection{ANÁLISE DO PADRÃO DE FRATURA}

Após a realização dos ensaios de resistência de união ao microcisalhamento, as superfícies dos espécimes foram examinadas com uma lupa estereoscópica com aumento de 57x (SZX9, Olympus, Tóquio, Japão) para determinação do modo de falha, classificando-as em falhas adesivas (na interface de união), coesivas (em dentina ou cimento) ou mistas.

\subsection{ANÁLISE DE MICROSCOPIA ELETRÔNICA DE VARREDURA}

Afim de ilustração, após a fratura, foi calculada a média da resistência de união para cada grupo, assim como a média de cada dente, selecionando-se para análise aquele cuja média mais se aproximasse da média do grupo, que seria, portanto, o que melhor o representaria. Foi separado um dente de cada grupo de contaminante cujo método de limpeza foi água, e um dente representativo dos outros métodos de limpeza para observação em microscopia eletrônica de varredura. A região de interesse da dentina foi removida utilizando-se uma broca multilaminada FG 12 em caneta de alta rotação sob refrigeração. Os espécimes foram lavados com jato de água abundantemente e bem secos. Foram montados em stubs metálicos e metalizados à vácuo com fina camada de platina (MED 010; Balzers Union, Balzers, Liechtenstein) (Figura 19) e observados sob magnificação utilizando um Microscópio Eletrônico de Varredura (JEOL SM-53210RLV, JEOL Brasil Inst. Cientificos Ltda., Sao Paulo, SP) (Figura 20). 


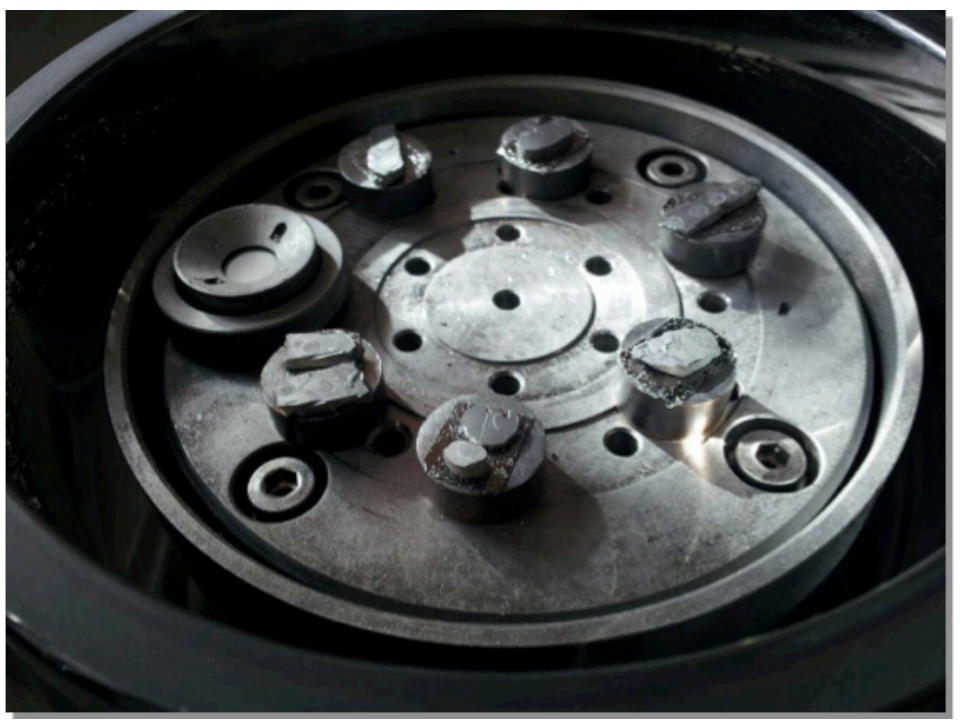

Figura 19 - Região da dentina em que os procedimentos adesivos foram realizados, montada em stub metálico e metalizada com fina camada de platina.

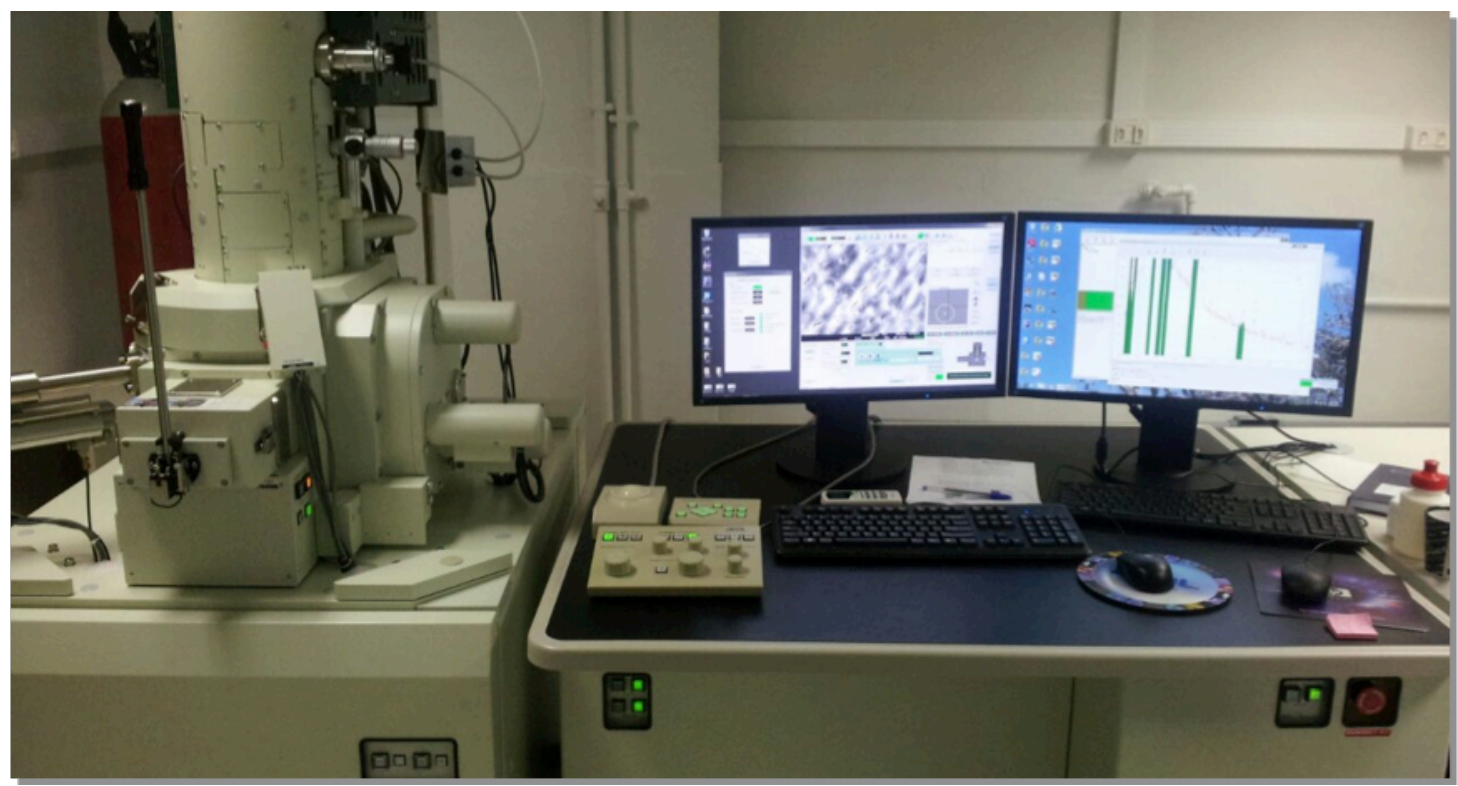

Figura 20 - Equipamento utilizado para análise de MEV. 


\subsection{ANÁLISE ESTATÍSTICA}

Os dados de resistência de união ao microcisalhamento foram submetidos à análise estatística através do software SPSS 17.0 (SPSS Inc., Chicago, IL, EUA), ao nível de significância de $5 \%$. Os valores de resistência de união foram avaliados quanto à homogeneidade das variâncias pelo teste de Levene, e quanto à normalidade de distribuição por meio do teste de Kolmogorov-Smirnov. Os dados foram então submetidos aos testes paramétricos de Análise de variânica a dois fatores (ANOVA twoway) para comparação entre as médias e teste complementar de Tukey para múltiplas comparações. Intenções foram tratadas por Análise de variância (ANOVA one-way) seguida pelo teste complementar de Tukey. 


\section{RESULTADOS}

\subsection{RESISTÊNCIA DE UNIÃO AO MICROCISALHAMENTO}

A análise de variância a dois fatores revelou uma significante diferença entre as médias de resistência de união dos grupos. Foi encontrada diferença estatisticamente significativa tanto em relação ao contaminante utilizado, quanto ao método de limpeza, assim como nas interações entre contaminante e limpeza $(p<0,05)$.

As médias, desvio padrão e intervalo de confiança $95 \%$ para a resistência de união à dentina com seus diferentes tratamentos, obtidas por meio do ensaio de microcisalhamento para o cimento resinoso auto-adesivo Rely X U200, estão apresentados na Tabela 4.

Quanto à contaminação, independente do método de limpeza, os maiores valores de $R U$ foram encontrados para o contaminante Sure (D) $(11,71 \mathrm{MPa})$, apresentando valores estatisticamente semelhantes à dentina que nao foi contaminada (C) $(11,14 \mathrm{MPa})$. Seguido do contaminante Visine $(E)(8,25 \mathrm{MPa})$, que foi estatisticamente semelhante ao ViscoStat Clear (VC) (6,74 MPa). O contaminante que mais prejudicou a resistência de união do cimento resinoso à dentina foi o ViscoStat (V) (5,45 MPa), não apresentando, todavia, diferença estatisticamente significante quando comparado ao ViscoStat Clear.

Quando analisado o método de limpeza, independentemente do agente contaminante, os métodos mais eficazes mostraram-se ser o uso da pasta à base de pedra-pomes e água (13,82 MPa) e jateamento de óxido de alumínio (13,01 MPa). Seguido do jato de água por 15 segundos $(7,14 \mathrm{MPa})$ que apresentou resultados estatisticamente semelhantes à aplicação de ácido fosfórico (5,5 MPa). O método de limpeza menos eficaz, influenciando negativamente nos resultados de resistência de união ao microcisalhamento, foi a aplicação de EDTA gel por 60 segundos $(2,25 \mathrm{MPa})$. 
Tabela 4. Valores de média, (desvio-padrão) e intervalo de confiança 95\% para média da resistência de união (MPa) ao microcisalhamento dos grupos testados.

\begin{tabular}{|c|c|c|}
\hline Grupos & Resistência de união (MPa) & IC 95\% \\
\hline $\mathrm{C}$ & $11,15(0,52)^{\text {DEFG }}$ & $10,05-12,24$ \\
\hline VW & $2,06(0,51)^{l}$ & $1,02-3,10$ \\
\hline VA & $0,98(0,39)^{\prime}$ & $0,18-1,78$ \\
\hline VE & $3,71(0,66)^{\mathrm{HI}}$ & $2,34-5,08$ \\
\hline VO & $9,52(0,86)^{F G}$ & $7,74-11,30$ \\
\hline VP & $16,64(0,94)^{A B C}$ & $14,68-18,60$ \\
\hline VCW & $3,35(1,06)^{\mathrm{HI}}$ & $1,20-5,50$ \\
\hline VCA & $7,06(0,99)^{\mathrm{GH}}$ & $5,00-9,13$ \\
\hline VCE & $2,85(0,90)^{\prime}$ & $0,98-4,73$ \\
\hline VCO & $12,06(1,01)^{\mathrm{CDEF}}$ & $9,96-14,17$ \\
\hline VCP & $10,22(0,81)^{\mathrm{EFG}}$ & $8,53-11,91$ \\
\hline EW & $16,11(0,82)^{A B C}$ & $14,40-17,82$ \\
\hline EA & $4,34(0,70)^{\mathrm{HI}}$ & $2,90-5,78$ \\
\hline EE & $1,35(0,34)^{\prime}$ & $0,66-2,04$ \\
\hline $\mathrm{EO}$ & $13,98(0,76)^{\mathrm{ABCDE}}$ & $12,39-15,56$ \\
\hline EP & $13,76(1,00)^{\mathrm{ABCDE}}$ & $11,67-15,86$ \\
\hline DW & $12,90(1,08)^{\mathrm{BCDEF}}$ & $10,62-15,17$ \\
\hline DA & $11,98(1,11)^{\mathrm{CDEF}}$ & $9,70-14,26$ \\
\hline $\mathrm{DE}$ & $1,72(0,50)^{\prime}$ & $0,67-2,77$ \\
\hline DO & $17,78(0,95)^{\mathrm{A}}$ & $15,77-19,79$ \\
\hline DP & $14,42(0,55)^{\mathrm{ABCD}}$ & $13,28-15,55$ \\
\hline
\end{tabular}

Letras diferentes indicam diferença estatística significante $(p<0,05)$. Letras iguais indicam semelhança estatística.

Pode-se melhor comparar os resultados obtidos de resistência de união sob microcisalhamento para os diferentes subgrupos analisando-se a Figura 21. 


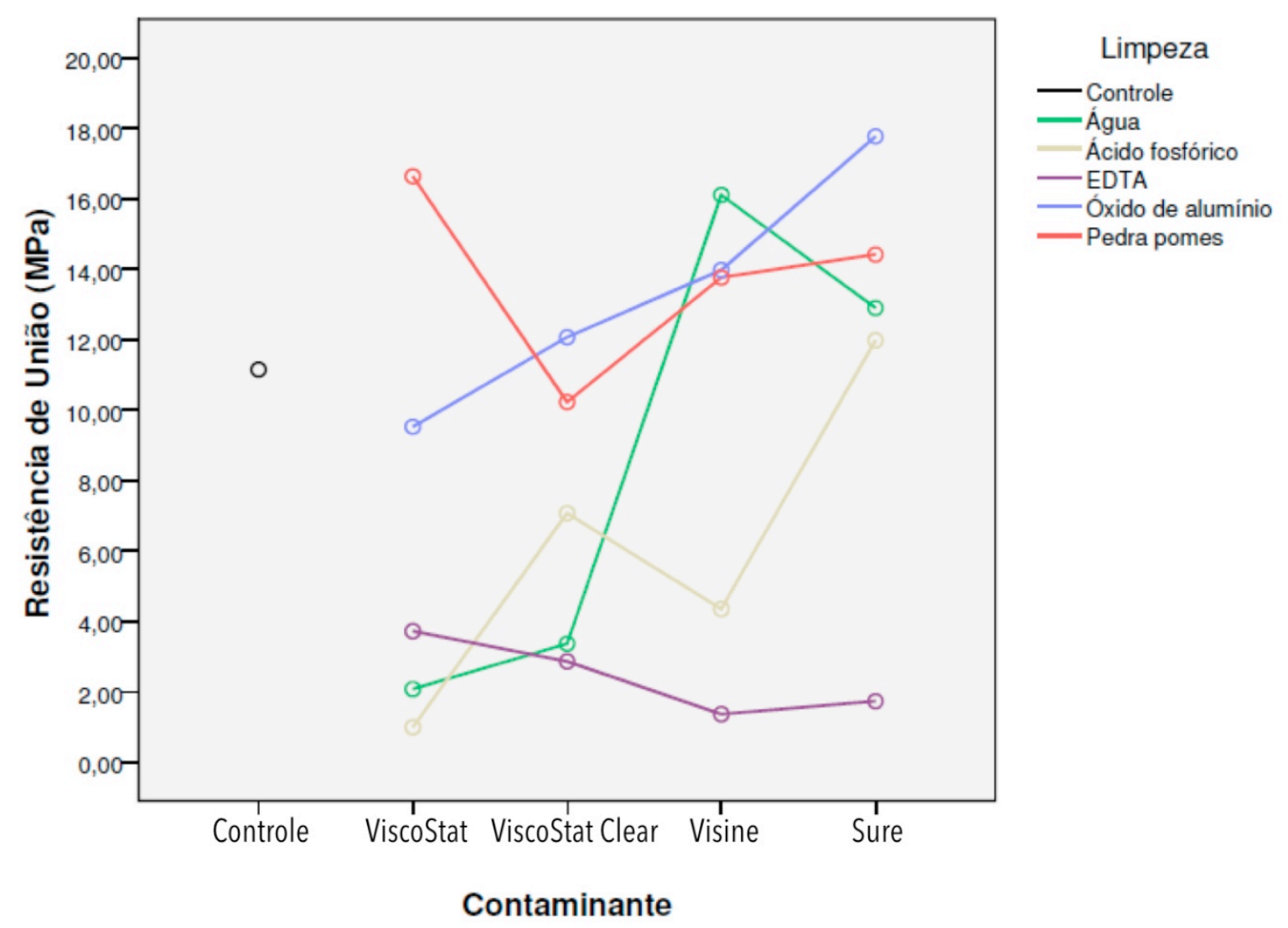

Figura 22 - Interação entre as variáveis de estudo Contaminante e Limpeza, e sua influência na resistência de união ao microcisalhamento.

Os menores valores de resistência de união, no geral, são atribuídos aos grupos cujos agentes contaminantes foram hemostáticos convencionais utilizados na Odontologia (ViscoStat e ViscoStat Clear), assim como também aos grupos cujos métodos de limpeza foram EDTA ou ácido fosfórico.

\subsection{ANÁLISE DO TIPO DE FRATURA}

Com relação ao tipo de fratura que foi realizado por meio de lupa estereoscópica, observou-se que quase todas as fratura foram do tipo adesiva (Tabela 5), podendo-se assim considerar válidos os valores correspondentes às resistências de união obtidos. 
Tabela 5. Porcentagem geral dos tipos de fratura.

\begin{tabular}{lcc}
\hline \multicolumn{1}{c}{ Tipos de fratura } & $\%$ & $\mathbf{n}$ \\
\hline Adesiva & $98.36 \%$ & 539 \\
Coesiva em dentina & $0 \%$ & 0 \\
Coesiva em cimento & $0 \%$ & 0 \\
Mista & $1,64 \%$ & 9 \\
\hline
\end{tabular}

\subsection{ANÁLISE DE MICROSCOPIA ELETRÔNICA DE VARREDURA}

Com relação a análise feita em MEV, a fotomicrografia obtida para o grupo C mostra presença de smear layer e maioria dos túbulos dentinários ocluídos (Figura 23). Um semelhante padrão acidificante para os agentes contaminantes V e VC (Figuras 24 e 25) com alguns túbulos parcialmente desocluídos.

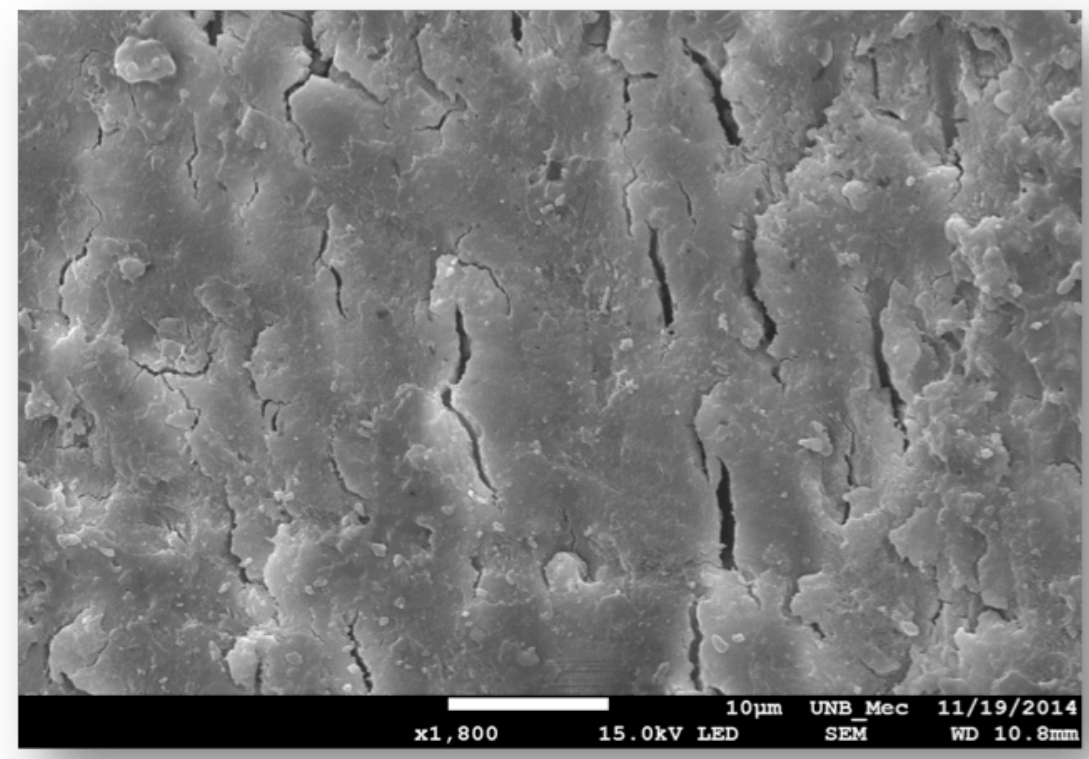

Figura 23 - Superfície dentinária do Grupo Controle. 


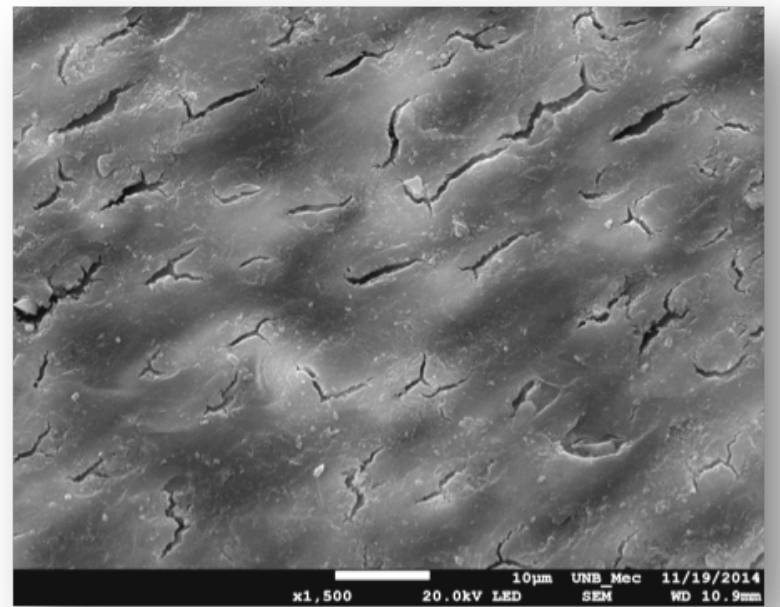

Figura 24 - Após 2 minutos de exposição à ViscoStat (grupo VW), seguido de jato spray de água por 15 segundos.

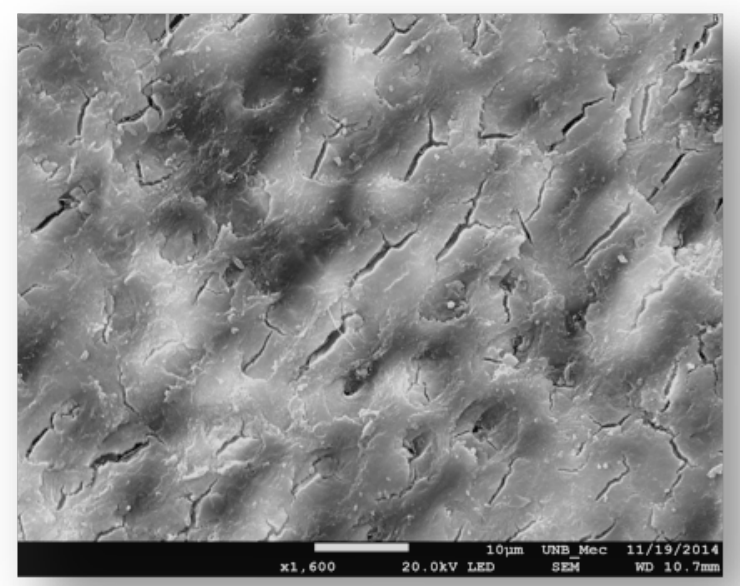

Figura 25 - Após 2 minutos de exposição à ViscoStat Clear (grupo VCW), seguido de jato spray de água por 15 segundos.

A fotomicrografia do contaminante E (Figura 26) revela remoção parcial da smear layer superficial e início de desmineralização dos smear plugs. Para o contaminante D (Figura 27), observa-se superfície irregular, com smear layer aparentemente intacta, e oclusão quase que total dos túbulos dentinários.

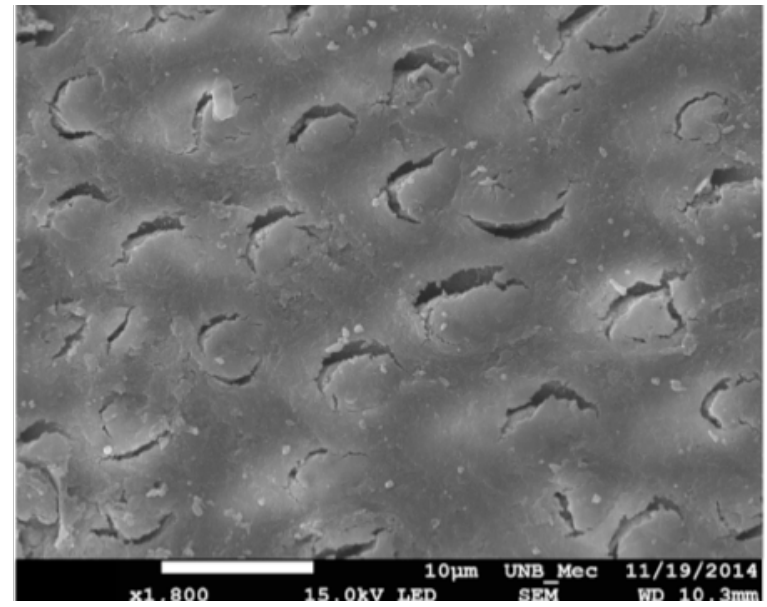

Figura 26 - Após 2 minutos de exposição à Visine (Grupo EW), seguido de jato spray de água por 15 segundos.

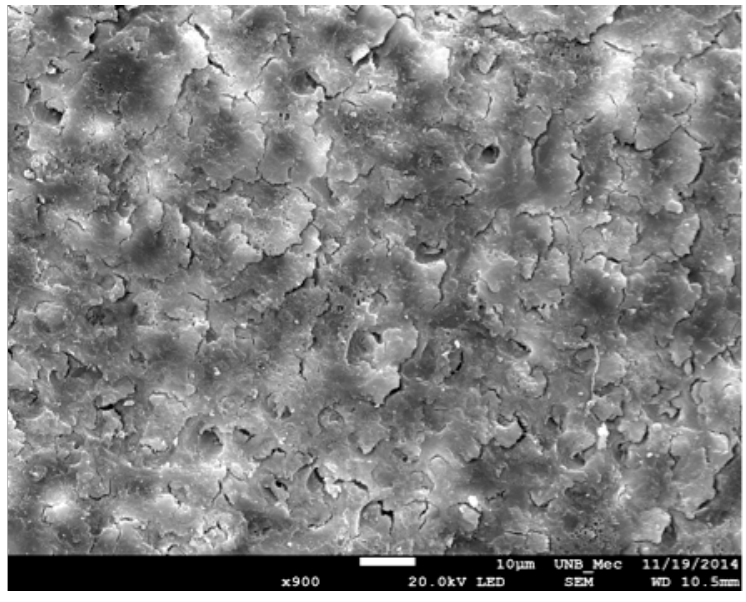

Figura 27 - Após 2 minutos de exposição à Sure (Grupo DW), seguido de jato spray de água por 15 segundos. 


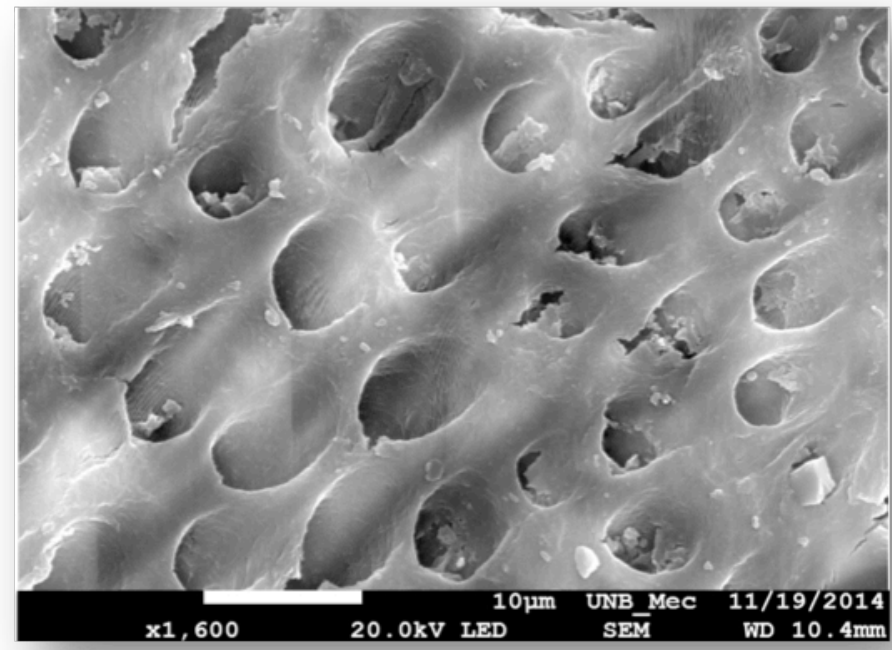

Figura 28 - Protocolo de limpeza ácido fosfórico $37 \%$ (Grupo VF).

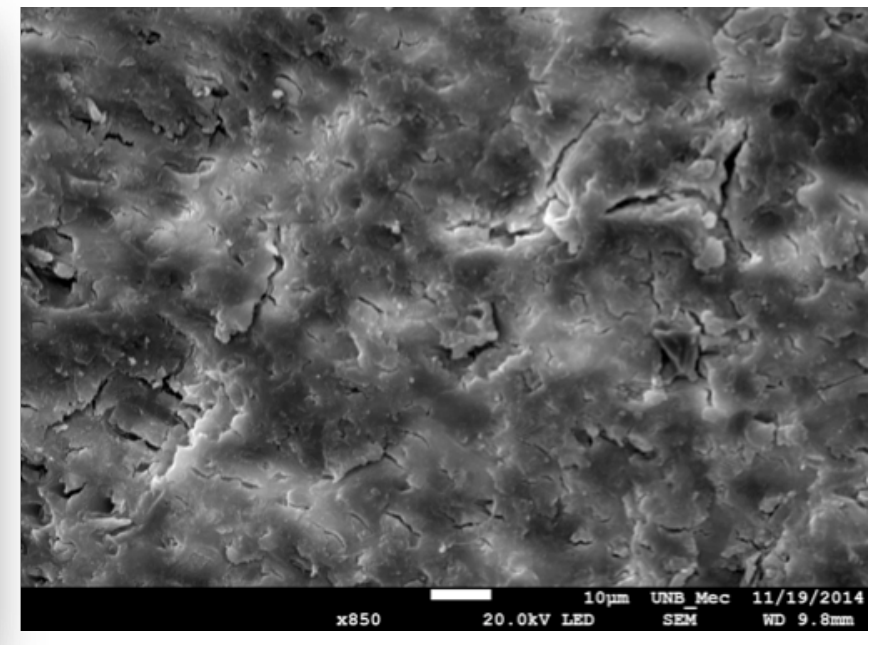

Figura 29 - Protocolo de limpeza jateamento com óxido de alumínio 90um (Grupo VCO).

$\mathrm{Na}$ fotomicrografia cujo método de limpeza utilizado foi ácido fosfórico (Figura 28), notamos remoção completa da smear layer, e total desobstrução dos túbulos dentinários, efeito oposto ao observado para o grupo óxido de alumínio (Figura 29).

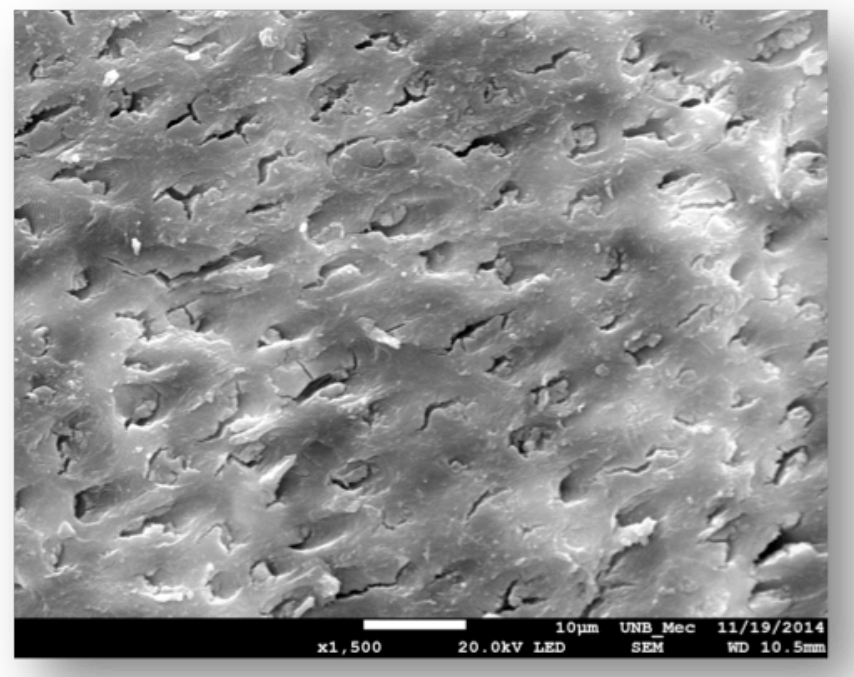

Figura 30 - Protocolo de limpeza EDTA (Grupo EE).

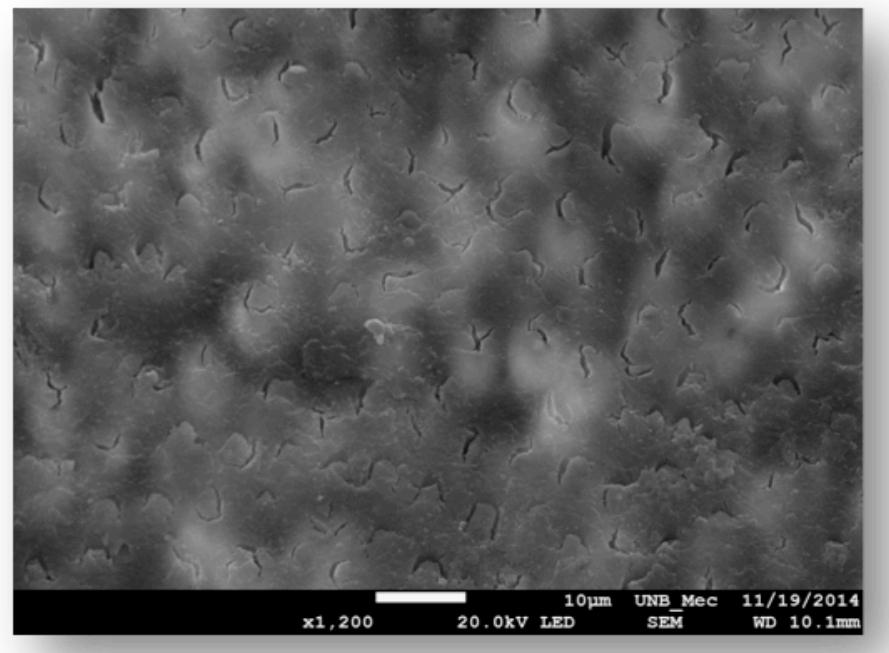

Figura 31 - Protocolo de limpeza Pedra-pomes (Grupo VP). 
A imagem para o método de limpeza EDTA (Figura 30) revela remoção parcial de smear layer com padrão indicativo de desmineralização e padrão tubular reconhecível de rachaduras na abertura dos túbulos dentinários. Para o protocolo de limpeza Pedra-pomes (Figura 31), a fotomicrografia revela túbulos dentinários ocluídos e remoção superficial de smear layer. 


\section{DISCUSSÃO}

Diversos tipos de contaminação podem afetar a estrutura e propriedades químicas dos materiais dentários restauradores. Fluidos orais como a saliva, sangue e fluido crevicular podem ocasionar incompatibilidade química com os materiais dentários (80) todavia, produtos utilizados para controlar tais fluidos, podem agir de igual forma ou ainda obstruir os túbulos dentinários impedindo o escoamento do material adesivo $(2,23)$.

Tendo em vista a necessidade de um campo descontaminado para se conseguir uma adesão confiável e duradoura $(81,82)$ este estudo avaliou a resistência de união de um cimento resinoso autoadesivo, por meio do ensaio mecânico de microcisalhamento à dentina em função do agente contaminante e método de limpeza utilizado.

Como o principal objetivo deste foi avaliar a resistência de união apenas entre o cimento e substrato dentário, optou-se pela utilização do método similar ao utilizado por Galun, Saleh e Lewinstein 1994, Abo-Hamar et al., 2005 e Sander et al., 2009, avaliando somente a interface adesiva dente/cimento desconsiderando o substrato da peça protética e a espessura do material cimentante, dessa forma, o cimento com formato de cilindro foi aplicado diretamente sobre a estrutura dentária, a fim de se obter dados de resistência de união do material cimentante apenas com a estrutura dentária, sem quaisquer interferências dos materiais restauradores $(83,50,58)$.

De acordo com os resultados obtidos verificou-se que houve diferença entre os dois fatores (contaminante e limpeza) envolvidos neste estudo $(p<0,05)$, observando-se ainda influência das interações entre os fatores $(p<0,05)$. Dessa forma, as hipóteses nulas testadas foram rejeitadas, ou seja, os diferentes contaminantes, os diferentes

protocolos de limpeza, e suas respectivas interações influenciam nos valores de resistência de união. 
Provavelmente pela simplicidade do método e facilidade de realização (65), os teste de cisalhamento sejam comumente empregados para avaliação da resistência de união de materiais à estrutura dentária. Além disso, são idealmente indicados para materiais friáveis, como cimentos, que se danificariam se submetidos ao preparo padrão de espécimes para microtração. As tensões são sensíveis à geometria do carregamento, forma e tamanho do aderente e seu módulo de elasticidade relativa (84). Os testes de microcisalhamento, quando comparados à seu correspondente "macro", apresentam-se ser mais confiáveis, devido à sua menor área de adesão, que reduz consideravelmente a porcentagem de falhas coesivas em material e substrato, assim como também, possibilita a confecção de vários espécimes em um único dente $(64,75)$.

Ao estudar a delimitação da área adesiva para o teste de microcisalhamento, Shimaoka, Andrade e Carvalho, 2007 encontraram diferença estatisticamente significante $(p<0,01)$ entre os grupos com e sem delimitação da área de adesão, concluindo que a delimitação da área interfere nos resultados de resitência de união. Isso se verificou uma vez que no grupo em que a área foi delimitada os valores de resistência de união apresentados foram inferiores aos do grupo controle. No grupo controle a área de adesão foi maior do que aquela usada para os cálculos de resistência de união devido ao escoamento do adesivo, sugerindo, portanto, que a delimitação da área aumenta a fidelidade dos resultados (85). Este estudo preconizou a delimitação da área de adesão através do uso da fita adesiva dupla face, evitando assim a formação de flash do material adesivo, comuns nesse tipo de ensaio, que influenciam na resistência de união registrada (64).

Apesar das vantagens apresentadas na utilização do tubo de amido para confecção dos cilindros de cimento, tais como: facilidade de inserção do material de teste, facilidade de remoção do tubo, aproximação das condições in vivo pela possibilidade de maior sorção de água pelo material resinoso (79), que certamente muito favoreceram para realização do teste; devido à dificuldade de se obter os cortes do tubo de amido completamente padronizados, resultando portanto em alturas diferentes, embora milimetricamente mínimas, a pressão simultânea dos espécimes por dente, como de costume por meio de uma lâmina de vidro sobreposta aos espécimes 
anterior à fotopolimerização não é viável para o método utilizado. Presume-se que os valores de resistência de união encontrados neste estudo sejam, portanto, inferiores aos que poderiam ser registrados em um estudo no qual fosse exercida pressão, assim como, clinicamente. Pois em virtude da alta viscosidade desses cimentos, deve-se considerar que outros fatores podem interferir no processo de adesão dos cimentos resinosos auto-adesivos, como a pressão exercida durante a cimentação.

Avaliações morfológicas revelaram que o Rely X Unicem (3M ESPE, St. Paul, MN, USA), antecessor do Rely X U200, deveria ser aplicado com alguma pressão para melhorar a adaptação às paredes da cavidade (49). Goracci et al., 2006 verificaram a influência da pressão de assentamento durante a cimentação e constataram que, embora esse fator não implicou decisivamente na resistência de união ao esmalte, em dentina teve efeito positivo ou benéfico. Em relação à morfologia da interface observada, por meio da microscopia eletrônica de varredura, os referidos autores observaram que a aplicação de pressão durante o assentamento pode contribuir para a redução de porosidades e da espessura do cimento, embora não tenha aumentado a penetração do mesmo nos subtratos dentinários, nem a formação de camada híbrida (55).

Embora o emprego de dentes humanos sejam preferíveis, dada a possibilidade de se testar a hipótese do estudo laboratorial em um substrato mais relevante clinicamente (86), devido à dificuldade de serem obtidos em quantidade suficiente e qualidade adequada, visto que, na maioria das vezes, são extraídos devido a lesões cariosas e outros defeitos e de ser um desafio controlar a fonte e a idade dos dentes coletados (87), a utilização de dentes bovinos in vivo e in situ vem sendo considerada em substituição aos dentes humanos. Além disso, a área de superfície relativamente pequena e curva dos dentes humanos pode ser uma limitação para testes específicos que requerem superfícies planas com espessuras uniformes (87).

Dessa forma, nos últimos 30 anos, o uso de dentes bovinos aumentou bastante em virtude da maior facilidade de obtenção em grande quantidade e em condições adequadas, livres de lesão cariosas e outros defeitos, com composição mais uniforme em relação aos dentes humanos (86) e com uma maior área de superfície plana (88). 
Diversos estudos avaliaram a resistência de união, tanto em esmalte (89-95) como em dentina $(89,90,93,95)$ comparando dentes humanos e dentes bovinos e observou-se que não houve diferença significante entre ambos, concluindo-se que os dentes bovinos podem ser considerados uma alternativa adequada aos dentes humanos em testes de resistência de união.

Dentre os estudos que avaliaram a influência de agentes hemostáticos na resistência de união de sistemas adesivos, grande diversidade entre os tempos de contaminação foi encontrada (25). Pesquisadores em três estudos utilizaram o tempo de contaminação de dois dias $(3,6,100)$, alguns 1 minuto $(4,99)$, outros 5 minutos $(8)$, mas a maioria estipulou o tempo de 2 minutos (1, 2, 5, 7, 11). Esse estudo adotou o tempo de 2 minutos, tendo em vista o maior número de publicações com esse tempo, e por poder ser considerado um tempo mínimo de ação na prática clínica.

Ainda com relação ao método de ensaio, a literatura reporta que as características da smear layer podem influenciar a resistência de união de alguns adesivos autocondicionantes de passo único (96). Clinicamente, a espessura de smear layer sobre a superfície dentinária varia com a rugosidade do instrumento de corte utilizado no preparo (97). A smear layer obtida com o uso de pontas diamantadas de granulação superfina é menos espessa do que aquela obtida com pontas diamantadas de granulação regular (98). Neste estudo, todas as superfícies de dentina tiveram suas smear layer padronizadas com o uso de uma lixa com granulação 600 , obtendo-se uma superfície similar à obtida com uma ponta diamantada de granulação fina ou superfina (98).

A dentina é um substrato heterôgeneo composto de mineral, de elementos orgânicos, basicamente colágeno tipo I e de água, contida principalmente no interior dos túbulos. Pode ser considerada como um complexo hidratado morfologicamente constituído por túbulos dentinários de material radial a partir da câmara pulpar até a junção amelodentinária (34).

Em baixo $\mathrm{pH}$ a hidroxiapatita, composto mineral presente na dentina, se solubiliza (99). Dos contaminantes utilizados neste estudo, sabe-se que possuem pH 
baixo o ViscoStat $(\mathrm{pH}=1,0)$ e ViscoStat Clear $(\mathrm{pH}=1,0)$ (informações dadas pelos fabricantes). Visine apresenta $\mathrm{pH}$ neutro $(\mathrm{pH}=6,8)(1)$, e desodorantes antitranspirantes, devido aos sais de alumínio presentes em sua composição, possuem pH mais básico. As imagens obtidas por microscopia eletrônica de varredura mostram um padrão semelhante de desmineralização da lama dentinária, com reconhecido padrão tubular apresentando rachaduras na abertura dos túbulos dentinários para os grupos VW e VCW. A imagem obtida por este estudo para o contaminante Visine parecem constratar com os achados de Land et al. (1), que observou que após 5 min. de contaminação a smear layer permaneceu completamente intacta, todavia, viu-se aqui que após 2 min., esse contaminante pareceu provocar remoção da smear layer superficial com início de desmineralização parcial dos smear plugs. O contaminante Sure, parece não influenciar na remoção de smear layer, contribuindo ainda, aparentemente, para a deposição de uma película amorfa sobre a superfície.

Em concordância com a literatura $(3,5,6,8$ 10, 24, 25, 100-103) os resultados mostram que somente o uso de água não é suficiente para remover os usuais agentes contaminantes utilizados na Odontologia, que mostraram influenciar grandemente os valores de resistência de união do cimento resinoso auto-adesivo. Todavia, para o grupo Visine esse método de limpeza apresentou o maior valor de resistência de união $(16,11 \mathrm{MPa})$, tornando-o superior ao controle $(11,15 \mathrm{MPa})(\mathrm{p}<0,05)$. De igual modo, para o grupo Sure, esse método demonstrou ser suficiente (12,90 MPa). Supõe-se todavia que esses resultados não estejam associados à capacidade da água como método descontaminante, mas sim aos agentes contaminantes utilizados, que parecem não prejudicar na resistência de união do cimento.

A adesão dos cimentos resinosos autoadesivos está sendo bastante investigada. Acredita-se que a mesma acontece de forma bastante complexa e parece envolver uma série de mecanismos relacionados à composição, reação de presa, interação com o cálcio do substrato dentário e neutralização do cimento. Estudos relataram que a propriedade autoadesiva do cimento Rely X Unicem é proporcionada, em parte, por um dos seus componentes, o ácido fosfórico metacrilato, que desmineraliza e infiltra-se na superfície dental, proporcionando retenção micromecânica $(42,50)$. 
As imagens de MEV mostraram que o método de limpeza Óxido de alumínio, possui capacidade de aumentar a energia de superfície do substrato dentário ao tornálo altamente irregular. O jateamento com óxido de alumínio, já utilizado na Odontologia para promover a limpeza de cavidades, produz uma superfície rugosa irregular com aumento da energia de superfície que aumenta a molhabilidade dos sistemas adesivos à superfície dentária providenciando retenção mecânica, similar ao que acontece com um esmalte acidificado (102). Quando o cimento é aplicado sobre esse tipo de superfície, os monômeros são levados para dentro das irregularidades por atração capilar. O fluxo de penetração dos adesivos nas áreas porosas pode favorecer uma união micro-mecânica. O método de limpeza Óxido de Alumínio foi eficaz para todos os contaminantes fazendo os grupos $\mathrm{VO}(9,52 \mathrm{MPa})$, $\mathrm{VCO}(12,06 \mathrm{MPa})$ e EO $(13,98 \mathrm{MPa})$ semelhantes ao Controle (11,15 MPa), e o grupo DO (17,78 MPa) estatisticamente superior.

A interação deste método de limpeza com o contaminante Sure, grupo em que houve maior valor de resistência de união, poderia formar dióxido de zircônio, composto encontrado na maioria das cerâmicas odontológicas (103), pela reação do zircônio presente no desodorante na forma de $\mathrm{Zr}_{3} \mathrm{Al}_{2}$, com o óxido presente no produto de limpeza na forma de $\mathrm{Al}_{2} \mathrm{O}_{3}$. $\mathrm{O}$ grupo éster fosfatado do monômero adesivo, une diretamente aos óxidos metálicos, assim, uma possível união química entre este grupamento e os óxidos de alumínio e zircônia poderia ter reforçado a resistência de união (106). Agentes cimentantes à base de monômero funcional, parecem promover a formação de ligações cruzadas do referido monômero com óxidos presentes na superfície cerâmica melhorando a qualidade de união entre cimento resinoso e o material cerâmico $(107,108)$. Esses monômeros são encontrados tanto em cimento resinoso, quanto em primer $(106,108)$.

Além disso, o condicionamento com ácido não produz qualquer modificação na superfície da zircônia (107), sendo, por isso, consideradas ácido resistentes (109) Assim sendo, a presença desse material policristalino pode ter desempenhado um papel protetor quando da utilização do método de limpeza Ácido fosfórico. Tal fato explicaria os resultados obtidos para o grupo DA (11,98 MPa). Apesar do Ácido 
fosfórico influenciar negativamente outros grupos de contaminantes, VA $(0,98 \mathrm{MPa})$ e EA (4,34 MPa) para DA (11,98 MPa) continuou a apresentar valores de resistência de união estatisticamente semelhante ao grupo Controle $(11,15 \mathrm{MPa})$.

Chaiyabutr e Kois, 2011 avaliaram a resistência de união de um cimento resinoso auto-adesivo à dentina contaminada com Viscostat Clear e Ferric Subsulfate Dental Gel sob três métodos de limpeza. A metodologia do trabalho em muito se difere deste, todavia, semelhante à este, comparando os métodos de limpeza: água, ácido fosfórico e óxido de alumínio, os autores encontraram os valores de resistência de união mais baixos para o grupo água, para ambos os contaminantes. Contraditoriamente, os autores não observaram diferença estatisticamente significante entre os métodos de limpeza ácido fosfórico e óxido de alumínio. Além disso o método de limpeza ácido fosfórico não demonstrou diferença estatisticamente significativa entre os contaminantes (8).

Vários estudos mostram que o efeito de agentes hemostáticos à base de $\mathrm{Fe}_{2}\left(\mathrm{SO}_{4}\right)_{3}$ parece ter um efeito mais acidificante sobre a dentina, quando comparado aos agentes à base de $\mathrm{AlCl}_{3}$. Land et al., relataram que 2 minutos de exposição a $15,5 \%$ de sulfato férrico resultou em efeito acidificante severo podendo este ser comparado à exposição a 21,3\% de Cloreto de Alumínio, quando este permanence em contato com a dentina por mais que o dobro do tempo (1). Chaiyabutr e Kois relataram que durante o mesmo período de tempo, os túbulos dentinários nos grupos contaminados com $\mathrm{AlCl}_{3}$ permaneciam ocluídos, com remoção parcial da smear layer. Enquanto que nos grupos de sulfato férrico os túbulos exibiam um claro efeito desmineralizador, ausência de smear plugs, com alguns túbulos parcialmente ocluídos (8).

Kuphasuk et al., 2007 e Harnirattisai et al., 2009 avaliaram a influência de 25\% de Cloreto de Alumínio na resistência de união de sistemas adesivos de condicionamento ácido total e observaram que o contaminante parece não influenciar negativamente na adesão desse sistema adesivo $(5,7)$, podendo ainda elevar os valores de resistência de união (5). Todavia quando a contaminação é realizada com agentes à base de Sufato de Ferro, diferentemente do que ocorre com Cloreto de 
Alumínio, a resistência de união é diminuída quando do uso desse sistema adesivo que faz uso prévio de ácido fosfórico $(3,100)$. Esses resultados mostram-se semelhantes ao encontrados pelo presente estudo, que encontrou grande influência do método de limpeza Ácido fosfórico para o contaminate ViscoStat, que demonstrou ser a pior interação $(0,98 \mathrm{MPa})$ e cuja microscopia eletrônica de varredura indica grande efeito desmineralizador, remoção completa da smear layer, e desobstrução dos túbulos dentinários. Em contrapartida quando contaminado com ViscoStat Clear (7,06 MPa) o grupo obteve resultado de resistência de união estatisticamente semelhante ao Controle (11,15 MPa).

$\mathrm{O} \mathrm{AlCl}_{3}$ quando reage com $\mathrm{H}_{3} \mathrm{PO}_{4}$ pode formar $\mathrm{AlPO}_{4}$ e $\mathrm{HCl}$. O AlPO 4 é um fosfato insolúvel conhecico como Alumino Fosfato (111). Imagens de microscopia eletrônica de varredura detectaram depósitos de precipitados granulares sobre a superfície de dentina após ser contaminada com um agente hemostático à base de Cloreto de Alumínio e posteriormente atacada com ácido fosfórico (2). O Fosfato de Alumínio embora possa se dissolver com o próprio subproduto da reação $(\mathrm{HCl})$, parece, a uma primeira instância, funcionar como barreira protetora contra a ação agressiva do Ácido fosfórico sobre a dentina. Todavia, o efeito acidificante quando do uso de agentes hemostáticos à base de Sulfato de ferro, parece ser redrobado devido ainda à sua hidrólise e possível formação de ácido sulfúrico (21).

Embora alguns estudos tenham demonstrado que o condicionamento do esmalte com ácido fosfórico, antes da aplicação do cimento autoadesivo, possa resultar em resistência de união comparável aos cimentos resinosos $(49,51,55)$ ou até mesmo superior (52), tendo em vista o aumento proporcional de microporosidades, pela utilização de um ácido mais forte (ácido fosfórico 37\%) quando em comparação com as produzidas, isoladamente, pelo cimento autoadesivo (49); tal concepção mostra-se desfavorável para a adesão em dentina $(49,51)$. O condicionamento com ácidofosfórico a $37 \%$ desmineraliza a dentina intertubular e peritubular (5-8 $\mathrm{m}$ de profundidade), expondo superficialmente a base da matriz de fibrilas de colágeno (112). Todavia, em virtude da alta viscosidade dos cimentos autoadesivos a sua difusão ou penetração entre as fibrilas de colágeno expostas é dificultada levando à formação de uma fraca 
união (49).

Essa dificuldade de difusão ou penetração do cimento entre as fibrilas de colágeno expostas pode ter sido responsável pelos baixos valores de resistência de união alcançados tanto pelo método de limpeza Ácido Fosfórico (5,5 $\mathrm{MPa})$, quanto $\operatorname{EDTA}(2,25 \mathrm{MPa})$.

O EDTA é um ácido orgânico fraco que tem ação quelante com concomitante desnaturação protéica $(113,114)$. Nos estudos de Blomlof et al.,(1997) e Cederlund et al., 2001, os autores encontraram que uma concentração de 15 a 24\% de EDTA foi suficiente para conseguir remover a smear layer superficial, e ocasionar a exposição de matriz colágena dos substrato dentinários hígido num tempo clínico aceitável de 2 min., comparada com concentrações mais baixas ou mais altas $(115,116)$. Hottel, El Refai e Jones, 1999 observaram que EDTA a uma concentração de 17\% demonstra total remoção da lama dentinária e uma abertura dos túbulos de 2,2 a $3,2 \mu \mathrm{m}$ (117). De acordo com Pashley, Stewart, e Galloway, EDTA pode agir até uma profundidade de 5 a $10 \mu \mathrm{m}(118)$.

Além disso o EDTA age seqüestrando de modo definitivo os íons metálicos $\mathrm{Pb}++, \mathrm{Zn++}, \mathrm{Co}++, \mathrm{Ni++}, \mathrm{Cd}++, \mathrm{Sn}++, \mathrm{Ca}++, \mathrm{Sr}++, \mathrm{Ba}++, \mathrm{Mg}++, \mathrm{Bi+++}$ e $\mathrm{Fe}+++(119)$.

Adicionalmente à adesão micromecânca obtida pelos cimentos resinosos autoadesivos, estudos relatam interação química entre os grupamentos de monômeros ácidos e hidroxiapatita $(35,42)$. Os grupamentos ácidos parecem se ligar com o cálcio da hidroxiapatita para formar uma ligação estável entre a rede de metacrilato e o dente (49). Alguns estudos $(49,54)$ afirmam que a interação entre a superfície dentária e os materiais cimentantes autoadesivos é superficial e irregular, sem desmineralização suficiente da smear layer e formação de autêntica camada híbrida, possivelmente sem a formação de tags de resina. Uma íntima adaptação do cimento autoadesivo à dentina através de microscopia eletrônica de varredura, sem evidenciação de formação da camada híbrida e tags resinosos, foi observada por alguns estudos, porém o mecanismo de união química nessa interface foi defendida $(49,51)$. Há indicações através de espectroscopia de fotoelétrons de raio-x de uma boa interação química com 
o cálcio da hidroxiapatita, o que sugere que esta via também proporciona um meio de retenção micromecânica, mesmo não havendo infiltração significante de mais de um micrometro na superfície da dentina (120).

Os cimentos autoadesivos contêm tradicionalmente partículas de carga em quantidade que varia de 60-75\% (121) e matriz orgânica com monômeros ácidofuncionais que promovem o mecanismo de desmineralização e adesão dos cimentos à hidroxiapatita (40). Há um grande número de monômeros ácidos, principalmente baseados em fosfatos e fosfanatos, que têm sido desenvolvidos especificamente para desmineralizar o esmalte e a dentina bem como para promover a formação de um sal estável envolvendo o Cálcio (41).

Como visto acima, outro fator que pode ter colaborado para os resultados dos valores encontrados para o método de limpeza EDTA, é o fato deste em sua ação quelante sequestrar os íons de Cálcio da hidroxiapatita, deixando pouco Cálcio livre para ligação química com o cimento.

Ajami et al., 2013 avaliando o efeito de três métodos de limpeza na resistência de união de um adesivo auto-condicionante (Clearfil S3 Bond) à dentina contaminada com um agente hemostático à base de Cloreto de alumínio concluiu que a aplicação de uma solução de 10\% EDTA por 60 segundos seguido de jato de água por 30 segundos reestabeleceu a resistência de união ao nível do grupo controle (24). Contraditoriamente aos resultados de Ajami et al., o presente estudo obteve para $24 \%$ EDTA gel, os piores valores de resistência de união (2,25 MPa).

Embora o produto utilizado neste estudo seja diferente, em concentrações e modo de apresentação, do utilizado por Ajami e colaboradores, presume-se, que a diferença encontrada nos resultados esteja relacionada com a viscosidade e mecanismo de ação dos materiais restauradores utilizados, e não às concentrações do produto de limpeza. Tendo em vista ainda que Soares et al., 2007, utilizando o mesmo produto do presente estudo (EDTA gel 24\%) avaliaram a eficácia de tratamentos prévios dos substratos dentais na força de adesão de dois adesivos autocondicionantes (Clearfil Protect Bond e One Up Bond F) sobre dentina tratada de 
diferentes formas: $\mathrm{C}$ - controle, sem tratamento prévio; TA - condicionamento com ácido fosfórico $37 \%$ no esmalte e dentina por 15s; $\mathrm{SB}$ - jateamento de $\mathrm{Al}_{2} \mathrm{O}_{3}$ na superfície dental; EDTA - esmalte e dentina condicionados com o gel de EDTA de $24 \%$; e concluíram que o tratamento prévio mais indicado para aumentar a força adesiva à dentina foi o uso de EDTA para ambos os sistemas adesivos (122). Esses resultados suportam a significante diferença encontrada nos resultados do presente estudo e de Ajami, demonstrando que o uso de EDTA não parece influenciar negativamente na resistência de união de sistemas adesivos auto-condicionantes à dentina, todavia não deve ser o protocolo de limpeza indicado quando se faz uso de cimentos resinosos auto-adesivos.

Quando comparado à água, o método de limpeza EDTA aumentou os valores de resistência de união apenas do grupo ViscoStat $(3,71 \mathrm{MPa})$, apresentando para todos os outros contaminantes, o pior desempenho. Como visto, o EDTA possui capacidade de sequestrar íons de ferro, assim sendo, a presença deste metal no contaminante pode ter competido com o cálcio da hidroxiapatita, diminuindo a disponibilidade de EDTA para este. Uma visível reação química com este agente contaminante pôde ser observada na confecção deste grupo.

O método de limpeza Pedra-pomes foi o que obteve melhor desempenho $(13,83$ $\mathrm{MPa})$, não sendo, todavia, estatisticamente diferente do Óxido de alumínio (13,02 MPa).

O método de limpeza com pedra-pomes, é um método tradicionalmente utilizado na Odontologia. O uso de uma pasta à base de pedra-pomes e água mostra-se um método adequado para promover a limpeza de contaminantes oleosos sobre a dentina para sistemas adesivos de condicionamento total (123). Esse método resulta em uma remoção parcial de smear layer e erosão superficial como consequência da abrasão mecânica das partículas de pedra-pomes (124). Este estudo observou considerável melhora nos valores de resistência de união, quando este método de limpeza foi utilizado, principalmente para o grupo Viscostat, que quando removido com água apresentou RUMC de 2,06 MPa, e quando removido com pedra-pomes esse valor atingiu $16,64 \mathrm{MPa}$, sendo estatisticamente superior ao grupo Controle $(11,15 \mathrm{MPa})$ $(p<0,05)$. 
Os agentes hemostáticos não usuais testados neste estudo, obtiveram os melhores valores de RUMC, principalmente o agente Sure, visto que o Visine teve sua média drasticamente reduzida pela interação com os métodos de limpeza Ácido fosfórico e EDTA; ao contrário deste, todavia, o Sure não foi afetado pelo Ácido fosfórico, provavelmente pela característica do zircônio, como exposto anteriormente. Possivelmente seus melhores resultados são devido à seus potenciais hidrogeniônicos neutro e básico, e incapacidade de alterar a morfologia da dentina, diferentemente dos agentes à base de $\mathrm{Fe}_{2}\left(\mathrm{SO}_{4}\right)_{3}$ e $\mathrm{AlCl}_{3}(1,2,22)$.

A tetrahidrozolina- $\mathrm{HCl}$, presente no Visine, já demonstrou eficácia hemostática (26), baixa citotoxicidade aos tecidos gengivais $(12,28)$ e seu uso na Odontologia tem sido sugerido desde 1996 (1). Todavia, a respeito do triclorohidrex alumino zirconio, composto presente nos desodorantes, embora sua ação controladora de fluidos seja inquestionável (33), seu possível uso na cavidade oral deve ser investigado.

Com relação à análise de falha para os ensaios de resistência de união ao microcisalhamento, o modo de fratura dos espécimes não foi reportado em alguns estudos $(78,125,126)$, uma vez que existe uma controvérsia na literatura com relação à confiabilidade dos dados obtidos na análise de falha em testes de cisalhamento para a determinação da resistência de união como um indicador do desempenho na adesão, em função da distribuição de tensões na interface adesiva (127). Entretanto, apesar dessa controvérsia e seguindo a tendência da maioria dos estudos que também realizaram o ensaio de microcisalhamento para determinação da resistência de união de adesivos autocondicionantes $(51,128-131)$, o presente estudo determinou o modo de fratura dos espécimes. Os resultados deste estão de acordo com os encontrados na literatura, que também relataram predominância de padrões de fratura do tipo adesiva $(51,128-131)$.

Em termos gerais, o protocolo de limpeza utilizado parece ser mais relevante e ter influenciado mais nos resultados de RUMC do que o agente contaminante. É importante notar que alguns protocolos de limpeza podem ser fortemente eficazes para um contaminante e não demonstrar resultados satisfatórios para outros. Vale lembrar que a suposição de que ácido fosfórico parece ser capaz de remover basicamente 
todos os contaminantes da superfície dentinária (4) e poderia servir como método de limpeza nos adesivos de condicionamento total (25), foi feita observando sua ação sobre contaminantes à base de $\mathrm{AlCl}_{3}$ e não deveria ser generalizada. Pois como demonstrado por este estudo, a respeito de contaminantes à base de $\mathrm{Fe}_{2}\left(\mathrm{SO}_{4}\right)_{3}$, este conceito não se aplica. Além da imprescindível necessidade de se observar a interação existente entre o método de limpeza e o agente contaminate é ainda válido considerar que alguns protocolos de limpeza podem ainda ter interação com o material restaurador utilizado, podendo apresentar excelente desempenho para alguns, e ser totalmente não desejável para outros. Como ocorre com o EDTA e sua distinta relação com sistemas adesivos autocondicionantes e cimentos resinosos autocondicionantes. Assim como também, apresentado foi, pelo estudo, da oportuna interação que parece existir entre Sure, Óxido de Alumínio e cimento resinoso autoadesivo. 


\section{Conclusão}

Tendo em vista a metodologia estabelecida, os materiais testados, e os resultados obtidos neste estudo, pode-se concluir que:

1. Na presença de contaminação com agentes hemostáticos, a utilização de um protocolo de limpeza adequado é de fundamental importância para estabelecer uma resistência de união aceitável do cimento RelyX U200 à dentina. Conhecer as possíveis interações do agente contaminante com o método de limpeza é essencial para melhor escolha deste.

2. O uso de água somente, como protocolo de limpeza, não é suficiente para promover a descontaminação da dentina.

3. O protocolo de limpeza Pedra-pomes apresentou o maior valor de resistência de união, demonstrando ser um protocolo eficaz para todos os tipos de contaminantes empregados neste estudo.

4. Em termos gerais, os protocolos de limpeza EDTA e ácido fosfórico não deveriam ser utilizados em procedimentos adesivos do cimento RelyX U200 à dentina.

5. Os agentes hemostáticos convencionais utilizados na Odontologia (ViscoStat e ViscoStat Clear) reduziram a resistência de união quando comparados aos novos produtos testados (Visine e Sure), todavia os protocolos de limpeza Pedra-pomes e Óxido de alumínio demonstraram ser totalmente eficazes elevando a resistência de união nestes grupos. 


\section{REFERÊNCIAS}

1. Land, MF; Couri, CC e Johnston, WM. Smear layer instability caused by hemostatic agents. J Prosthet Dent. 1996, v. 76, n. 5, p. 477-482.

2. Ayo-Yussuf, OA; Driessen, $\mathrm{CH}$ e Botha, AJ. SEM-EDX study of prepared human dentine surfaces exposed to gingival retraction fluids. J Dent. 2005 , v. 33 , n. 9, p. 731 739.

3. Salama, FS. Influence of zinc-oxide eugenol, formocresol, and ferric sulfate on bond strength of dentin adhesives to primary teeth. J Contemp Dent Pract. 2005, v. 6, n. 3, p. 14-21.

4. Kimmes, NS; et al. Effect of ViscoStat and ViscoStat Plus on composite shear bond strength in the presence and absence of blood. J Adhes Dent. 2006, v. 8, n. 6, p. 363366.

5. Kuphasuk, W; et al. Bond strengths of two adhesive systems to dentin contaminated with a hemostatic agent. Oper Dent. 2007, v. 32, n. 4, p. 399-405.

6. Prabhakar, AR e Bedi, S. Effect of glutaraldehyde and ferric sulfate on shear bond strength of adhesives to primary dentin. J Indian Soc Pedod Prev Dent. 2008, v. 26, suppl 3, p. S109-S113.

7. Harnirattisai, C; et al. Bond strengths of resin cements to astringent-contaminated dentin. Oper Dent. 2009, v. 34, n. 4, p. 415-422.

8. Chaiyabutr, Y e Kois, JC. The effect of tooth-preparation cleansing protocol on the bond strength of self-adhesive resin cement to dentin contaminated with a hemostatic agent. Oper Dent. 2011, v. 36, n. 1, p. 18-26.

9. Tarighi, $\mathbf{P}$ e Khoroushi, $\mathbf{M}$. A review on common chemical hemostatic agents in restorative dentistry. Dent Res J (Isfahan). 2014, v. 11, n. 4, p. 423-428. 
10. Arslan, S; Ertas, H e Zorba, YO. Influence of Ankaferd Blood Stopper on shear bond strength of bonding systems. Dent Mater J. 2012, v. 31, n. 2, p. 226-331.

11. Mohammadi, $\mathbf{N}$; et al. Effect of aluminum chloride hemostatic agent on microleakage of Class $\mathrm{V}$ composite resin restorations bonded with all-in-one adhesive. Med Oral Patol Oral Cir Bucal. 2012, v. 17, n. 5, p. e841-e844.

12. Nowakowska, D; et al. Dynamic oxidoreductive potential of astringent retraction agents. Folia Biol (Praha). 2010, v. 56, n. 6, p. 263-268.

13. Donovan, TE; Gandara , BK e Nemetz , H. Review and survey of medicaments used with gingival retraction cords. J Prosthet Dent. 1985, v. 53, n. 4, p. 525-531.

14. Kóstic, l; et al. Comparative review of gingival retraction agents. Act Med Mediana. 2012 , v. 51 , n. 1 , p. $81-84$.

15. Mohan , M; et al. Pharmacological agents in dentistry: A review. Br J Pharm Res. 2011 , v. 1 , n. 3, p. 66-87.

16. Strassler, HE e Boksman, L. Tissue management, gingival retraction and hemostasis. Oral Health. 2011, p. 101-135.

17. Gupta, GK; et al. Astringents in dentistry: A review. Asian J Pharm Health Sci. 2012, v. 2, n. 3, p. 428-432.

18. Prasad, K; et al. Gingival displacement in prosthodontics: A critical review of existing methods. J Interdiscip Dent. 2011, v. 1, n. 2, p. 80-86.

19. Jain, S; Sharma, R e Ramola, V. Review of various gingival retraction chemicals used in dentistry. Heal Talk. 2012, v. 4, n. 6, p. 25-26.

20. Weir, DJ e Williams, BH. Clinical effectiveness of mechanical-chemical tissue displacement methods. J Prosthet Dent. 1984, v. 51, n.3, p. 326-329.

21. Woody, RD; Miller, A e Staffanou, RS. Review of the $\mathrm{pH}$ of hemostatic agents used in tissue displacement. J Prosthet Dent. 1993, v. 70, n.2, p. 191-192. 
22. Land, MF; Rosentiel, SF e Sandrick, JL. Disturbance of the dentinal smear layer by acidic hemostatic agents. J Prosthet Dent. 1994, v. 72, n.1, p. 4-7.

23. Sung , EC; et al. Effects of irrigation solutions on dentin bonding agents and restorative shear bond strength. J Prosthet Dent. 2002, v. 87, n.6, p. 628-632.

24. Ajami, AA; et al. Effect of three different contamination removal methods on bond strength of a self-etching adhesive to dentin contaminated with an aluminum chloride hemostatic agent. J Contemp Dent Pract. 2013, v. 14, n.1, p. 26-33.

25. Bernades, KO; et al. The influence of hemostatic agents on dentin and enamel surfaces and dental bonding: A systematic review. JADA. 2014, v. 145, n.11, p. 11201128.

26. Bowles, WH; Tardy, SJ e Vahadi, A. Evaluation of new gingival retraction agents. $J$ Dent Res. 1991, v. 70, p. 1447-1449.

27. Tardy, SJ; Bowles, WH e Chambless, IA. Clinical evaluation of visine as gingival retraction agent. 1990, v. 69 , p. $250-254$.

28. Nowakowska, D; et al. Cytotoxic potential of vasoconstrictor experimental gingival retraction agents - in vitro study on primary human gingival finroblast. Folia Biologica (Praha). 2012, v. 58, p. 37-43.

29. Holzle, E. Topical pharmacological treatment. Cuu Probl Dermatol. 2002, v.. 30, p. 30-43.

30. Holzle , E e Braun-Falco, O. Structural changes in axillary eccrine glands following long-term treatment with aluminum chloride hexahydrate solution. $\mathrm{Br} J$ Dermatol. 1984, v. 110 , p. $399-403$.

31. Yazici, AR; et al. The effect of saliva contamination on microleakage of an etchand-rinse and a self-etching adhesive. J Adhes Dent. 2007, v. 9, p. 305-309. 
32. Mohammadi, $\mathbf{N}$; et al. Effect of aluminum chloride hemostatic agent on microleakage of Class $\mathrm{V}$ composite resin restorations bonded with all-in-one adhesive. Med Oral Patol Oral Cir Bucal. 2012, v. 17, n. 5, p. e841-e844.

33. Pariser, DM e Ballard, A. Topical therapies in hyperhidrosis care. Dermatol Clin. 2014, v. 32, n. 4, p. 485-490.

34. Nakabayashi, N e Pashley, DH. Hibridization of dental hard tissues. Quintessence. 1 ed São Paulo, 1998, p. 129.

35. Radovic, I; et al. Self-adhesive resin-cements: A Literature Review. J Adhes Dent. 2008 , v. 10 , n. 4 , p. 158-251.

36. Barcellos, DC; et al. Evaluation of bond strength of self-adhesive cements to dentin with or without application of adhesive system. J Adhes Dent. 2011, v. 13, p. 261-265.

37. Manso, AP; et al. Cements and adhesives for all-ceramic restorations. Dent Clin N Am. 2011, v. 55, n. 2, p. 311-332.

38. Viotti, RG; et al. Microtensile bond stregth of new self-adhesive luting agents and conventional multistep systems. J Prosthet Dent. 2009, v. 102, n.5, p. 306-312.

39. Duke, ES. New technology directions in resin cements. Compend Contin Educ Dent. 2003 , v. 24, n. 8 , p. $606-608$.

40. Burguess, JO; Ghuman, T e Cakir, D. Self-adhesive resin-cements. J Esthet Restor Dent. 2010, v. 22, n.6, p. 412-419.

41. Ferracane, JL; Stansbury, JW e Burke, FJT. Self-adhesive resin cements chemistry, properties and clinical cnsiderations. J Oral Rehabil. 2011, v. 38, n. 4, p. 295314.

42. Gerth, HU; et al. Chemical analysis and bonding reaction of RelyX Unicem and Bifix composites - a comparative study. Dent Mater. 2006, v. 22, n.10, p. 934-941. 
43. Pavan, S; Berger, S e Bedran-Russo, AKB. The effect of dentin pretreatment on the microtensile bond strength of self-adhesive resin cements. J Prost Dent. 2010, v. 104 , n. 4 , p. $258-264$.

44. Kumbuloglu , O; et al. A study of the physical and chemical properties of four rein composite luting cements. Int J Prosthodont. 2004, v. 17, n. 3, p. 357-363.

45. Myers, ML, Caughman, WF e Rueggeberg, FA. Effect of restoration composition, shade, and thickness on the cure of a photoactivated resin cement. $J$ Prosthodont. 1994 , v. 3, n. 3, p. 194-157.

46. Guarda, GB, et al. Luting glass ceramic restorations using a self-adhesive resin cement under different dentin conditions. J Appl Oral Sci. 2010, v. 18, p. 244-248.

47. De Souza Costa, CA, Hebling, J e Randall, RC. Human pulp response to resin cements used to bond inlay restorations. Dent Mater. 2006, v. 22, n. 1, p. 954-962.

48. De Mendonça , AA, et al. Cytotoxic effects of hard-setting cements applied on the odontoblast cell line MDPC-23. Oral Surg Oral Med Oral Pathol Oral Raiol. 2007, v. 104, n. 4, p. e102-e108.

49. De Munck, J, et al. Bonding of an auto-adhesive luting material to enamel and dentin. Dent Mater. 2004, v. 20, n. 10, p. 963-971.

50. Abo-Hamar , SE; et al. Bond strengh of a new universal self-adhesive resin luting cement to dentin and enamel. Clin Oral Invest. 2005, v. 9, n. 3, p. 161-167.

51. Hikita, K; et al. Bonding effectiveness of adhesive luting agents to enamel and dentin. Dent Mater. 2007, v. 23, n.1, p. 71-80.

52. Duarte, S Jr; et al. Microtensile bond strengths and scanning electron microscopic evaluation of self-adhesive and self-etch resin cements to intact and etched enamel. $J$ Prosthet Dent. 2008, v. 100, n. 3, p. 203-210.

53. Luthy, H; Loeffel, O; e Hammerle, $\mathrm{CH}$. Effect of thermocycling on bond strength of luting cements to zirconia ceramic. Dent Mater. 2006, v. 22, n. 2, p. 195-200. 
54. Al-Assaf, K; et al. Interfacial characteristics of adhesive luting resins and composites with dentin. Dent Mater. 2007, v. 23, n. 7, p. 829-839.

55. Goracii, C; et al. Microtensile bond strength and interfacial properties of self-etching and self adhesive resin cements used to lute composite onlays under different seating forces. J Adhes Dent. 2006, v. 8, n. 5, p. 327-335.

56. Peutzfeldt, A, Sahafi, A e Flury, S. Bonding of restorative materials to dentin with various luting agents. Oper Dent. 2011, v. 36, n. 3, p. 266-273.

57. Turkmen, C; et al. Tensile bond strength of indirect composites luted with three new self-adhesive resin-cements to dentin. J Appl Oral Sci. 2011, v. 19, n. 4, p. 363-369.

58. Sander, RF; et al. Resitência de união ao cisalhamento de cimentos resinosos autocondicionantes à dentina. Rv Clin Pesq Odontol. 2009, v. 5, n. 3, p. 273-279.

59. Christensen, GJ. Resin cements and postoperative sensitivity. J Am Dent Assoc. 2000 , v. 131, n. 8, p. 1197-1199.

60. Taschner, M; et al. IPS Empress inlays luted with a self-adhesive resin cement after 1 year. 2009 , v. 22 , n. 1 , p. 55-9.

61. Blatz, MB; et al. Postoperative tooth sensitivity with a new self-adhesive resincement - a randomized clinical trial. Clin Oral Investig. 2012, v. 17, n. 3, p. 793-798.

62. Stanley, HR. An urgent plea for a standardized bonding (adhesion) test. J Dent Res. 1993, v. 10, p. 1362-1363.

63. Rueggeberg, FA. Substrate for adhesion testing to tooth structure - review of the literatura. Dent Mater. 1991, v. 7, p. 2-10.

64. Armstrong, S; et al. Adhesion to tooth structure: A critical review of "micro" bond strength test methods. Dent Mater. 2010, Vol. 26, pp. e5-e62.

65. Braga , RR; et al. Adhesion to tooth structue: A critical review of "macro" test methods. Dent Mater. 2010, v. 26, p. e38-e49. 
66. Van Noort, R; et al. A critique of bond strength measurements. J Dent. 1989, v. 17, p. 61-67.

67. Pashley, DH; et al. Adhesion testing of dentin bonding agents: a review. Dent Mater. 1995, v. 11, p. 117-125.

69. Pashley, DH; et al. The microtensile bond test: a review. J Adhes Dent. 1999, v. 1, n.4, p. 299-309.

70. Shono, Y; et al. Regional measurements of resin-dentin bonding as an array. J Dent Res. 1999, v. 78, n. 2, p. 699-705.

71. Phrukkanon, S; Burrow, MF e Tyas, M. Effect of crosssectional surface area onbond strengths between resin and dentin. Dent Mater. 1998, v.14, p. 120-128.

72. Shimada, Y; Yamaguchi, S e Tagami , J. Micro-shear bond strength of dual-cured resin cement to glass ceramics. Dent Mater. 2002, v. 18, n. 5, p. 380-388.

73. Placido, E; et al. Shear versus micro-shear bond strength test: A finite elemente stress nalysis. Dent Mater. 2007, v. 23, n. 9, p. 1086-1092.

74. McDonough , WG; et al. A microshear test to measure bond strengths to dentinpolymer interfaces. Biomater. 2002, v. 23, n. 17, p. 3603-3608.

75. Banamyong, D; et al. Effect of dentin conditioning on dentin permeability and microshear bod strength. Eur J Oral Sci. 2007, v. 115, n. 6, p. 502-509.

76. Yoo, HM; Oh, TS e Pereira; PNR. Effect of saliva contamination on the microshear bond strength of one-step self etching adhesive systems to dentin. Oper Dent. 2006, v.31, n. 1 , p. 127-134.

77. Costa, LA; et al. Evaluation of $\mathrm{pH}$, ultimate tensile strength, and micro-shear bond strength of two self-adhesive resin cements. Braz Oral Res. 2014, v. 28, n. 1, p. 1-7.

78. Sadr, A; et al. Effects of storage time and temperature on the prperties of two selfetching systems. J Dent. 2007, v. 35, p. 218-225. 
79. Tedesco, TK; et al. Starch tubinf: an alternative method to build up microshear bond test specimens. J Adhes Dent. 2013, v. 15, n. 4, p. 311-315.

80. Powers, JM; O'Keefe, KL e Pinzon, LM. Factors affecting in vitro bond strength of bonding agents to human dentin. Odontology. 2003, v. 91, n. 1, p. 1-6.

81. Xie, J; Powers, JM e McGukin, RS. In vitro bond strength of two adhesives to enamel and dentin under normal andcontaminated cnditions. Dent Mater. 1993, v. 9, n. 5, p. 295-299.

82. Dietrich, T; et al. Influence of dentin conditioning and contamination on the marginal integrity of sandwich Class II restorations. Oper Dent. 2000, v. 25, n. 5, p. 401-410.

83. Galun, EA; Saleh, $\mathbf{N}$ e Lewinstein, I. Diametral tensile strength and bonding to dentin of type I glass ionomer cements. J Prosthet Dent. 1994, v. 72, n. 4, p. 424-429.

84. Van Noort, R; et al. A critique of bond strength measurements. J Dent. 1989, v. 17, n. 2, p. 61-67.

85. Shimaoka, AM; Andrade, AP e Carvalho, RCR. Influência da delimitação da área adesiva eme estudos laboratoriais para mensuração de resistência adesiva. RPG Rev Pós-Grauação. 2007, v. 14, n. 2, p. 174-178.

86. Yassen, GH; Platt, JA e Hara, AT. Bovine teeth as substitute for human teeth in dental research: a review of literature. J Oral Sci. 2011, v. 53, n. 3, p. 273-282.

87. Zero, DT. In situ caries models. Adv Dent Res. 1995, v. 9, n. 3, p. 214-230.

88. Melberg, JR. Hard tissue ubstrates for evaluation of cariogenic an anti-cariogenic activity in situ. J Dent Res. 1992, v. 8, n. 4, p. 265-269.

89. Nakamishi, I; Iwaku, M e Fusayama, T. Bovine teeth as possible substitutes in the adhesion test. J Dent Res. 1983, v. 62, n. 10, p. 1076-1081.

90. Fowler, CS; et al. Influence of selectes variables on adhesion testing. Dent Mater. 1992 , v. 8, n. 4 , p. $265-269$. 
91. Shahabi, S; Brockhurst, PJ e Walsh, LJ. Effect of tooth-related factors on the shear bond strengths obtained with Co2 laser conditioning of enamel. Aust Dent J. 1997, v. 42, n. 2, p. 81-84.

92. Lopes, MB, et al. Comparative study of the dental substrate used in shear bond strength tests. Pesqui Odontol Bras. 2003, v. 17, n. 2, p. 171-175.

93. Reis, AF, et al. Comparison of microtensile bond strength to enamel and dentin of human, bovine and porcine teeth. J Adhes Dent. 2004, v. 6, n.2, p. 117-121.

94. Titley, KC; Childers, S e Kulkarni, G. An in vitro comparison of short and long term bond strengths of polyacid modified composite resins to primary human and bovine enamel and dentine. Eur Arch Paediatr Dent. 2006, v. 7, n.4, p. 246-252.

95. Krifka, S; et al. Bond strength of adhesive systems to dentin and enamel - human vs. bovine primary teeth in vitro. Dent Mater. 2008, v. 24, n.7, p. 888-894.

96. Inoue, $\mathrm{H}$; et al. Microtensile bond strength of two single-step adhesive system to bur-prepared dentin. J Adhes Dent. 2001, v. 3, n.2, p. 129-136.

97. Sasakawa, W; et al. Microshear bond strength of five single-step adhesives to dentin. Dent Mater. 2005, v. 24, n.4, p. 617-627.

98. Tani, C e Finger, WJ. Effect of smear layer thickness on bond strength mediated by three all-in-one self etching priming adhesives. J Adhes Dent. 2002, v. 4, n.4, p. 283289.

99. Fushida, CE e Cury, JA. Estudo in situ do efeito da frequência de ingestão de Coca-Cola na erosão do esmalte-dentina e reversão pela saliva. Rev Odontol USP. 1999, v. 13, n.2, p.127-134.

100. Ebrahimi, SF; Shadman, $\mathbf{N}$ e Abrishami, A. Effect of ferric sulfate contamination on the bonding effectiveness of etch-and-rinse and self-etch adhesives to superficial dentin. J Conserv Dent. 2013, v. 16, n.2, p. 126-130. 
101. Shalan, H; Awad, S e El-Fallal, AA. Influence of pulpotomy medicaments on the ultrastucture and shear bond strength of a self-etch adhesive to primary tooth dentin. Quintenssence Int. 2012, v. 43, n.6, p. 517-523.

102. Kilic, K; et al. Do blood contamination and haemostatic agents affect microtensile bond strength of dual cured resin cement to dentin? J Appl Oral Sci. 2013, v. 21, n.1, p. 85-91.

103. Ulusoy, AT; et al. Effect of new haemostatic agent on microtensile bond strength of two adhesive systems to dentin. Mater Res Innov. 2011, v. 15, n.5, p. 330-334.

104. Roeder , LB; et al. Bond strength of composite to air-abraded enamel and dentin. Oper Dent. 1995, v. 20, n.5, p. 186-190.

105. Kelly, JR e Denry, I. Stabilized zirconia as a structural ceramic: An overview. Dent Mater. 2008, v. 24, p. 289-298.

106. Wolfart, M; et al. Durability of the resin bond strength to zirconia ceramic after using different surface conditioning methods. Dent Mater. 2007, v. 23, n.1, p. 45-50.

107. Gomes, AL; et al. Influence of sandblasting granulometry and resin cement composition on microtensile bond strength to zirconia ceramic for dental prosthetic frameworks. J Dent. 2013, v. 41, n.1, p. 31-41.

108. Cavalcanti, AN; et al. Bond strength $f$ resin cements to a zirconia ceramic with different surface treatments. Oper Dent. 2009, v. 32, n.3, p. 280-287.

109. Blatz, MB; Sadan, A e Kern, M. Resin-ceramic bonding: a review of the literature. J Prosthet Dent. 2003, v. 89, n.3, p. 268-274.

110. Della Bona, A; et al. Characterization and surface treatment effects on topography of a glass-infiltrated alumina/zirconia-reinforced ceramic. Dent Mater. 2007, v. 23, n.6, p. 769-775.

111. Greenwood, NN e Earnshaw, A. Chemistry of the Elements. 2 ed. London: Elsevier, 1997, p. 63. 
112. Pashley, DH; et al. State of the art etch-and-rinse adhesives. Dent Mater. 2011, v. 27 , n.1, p. 1-16.

113. Sousa-Neto, MD; et al. Evaluation of the effect of EDTA, EGTA and CDTA on dentin adhesiveness and microleakage with different root canal sealers. Braz Dent $\mathrm{J}$. 2002, v. 13, n.2, p. 123-128.

114. Hulsmann, M; Heckendorff, M e Lennon, A. Chelating agents in root canal treatment: mode of action and indications for their use. Int Endod J. 2003, v. 36, n.12, p. 810-830.

115. Blomlof, J; Blomlof, L e Lindskog, S. Effect of different concentrations of EDTA on smear removal and collagen exposure in periodontitis-affected root surfaces. J Clin Periodontol. 1997, v. 24, n.8, p. 534-537.

116. Cederlund, A; Jonsson, B e Blomlof, J. Shear strength after ethylenediaminetetraacetic acid conditioning of dentin. Acta Odontol Scand. 2001, v. 59, n.6, p. 418-422.

117. Hottel , TL; EI Refai, NY e Jones, JJ. A comparison of the effects of three chelating agents on the root canals of extracted teeth. J Endod. 1999, v. 25, p. 716-722.

118. Pashley, DH; Stewart, FP e Galloway, SE. Effects of air-drying on dentin human permeability. Arch Oral Biol. 1984, v. 29, n.5, p. 379-383.

119. Voguel A. Análise inorgânica quantitativa. 4 ed. Rio de Janeiro : Guanabara, 1981, p. 197-198.

120. Monticelli, F; et al. Limited decalcification/diffusion of self-adhesive cements into dentin. J Dent Res. 2008, v. 87, n.10, p. 974-979.

121. Belli, $\mathbf{R}$, et al. In vitro wear gap formation of self-adhesive resin cements: a CLSM evaluation. J Dent. 2009, v. 37, n.12, p. 984-993.

122. Soares, CJ; et al. Effect of precious tratments on bond trength of two self-etchinf adhesive systems to dental substrate. J Adhes Dent. 2007, v. 9, n.3, p. 291-296. 
123. Matos, $\mathbf{A B}$; et al. Influence of oil contamination on in vitro bond strength of bonding agents to dental substrates. Am J Dent. 2008, v. 21, n.2, p. 101-104.

124. Grasso, CA; et al. In vivo evaluation of three cleansing techniques for prepared abutment teeth. J Prost Dent. 2002, v. 88, n.4, p. 437-441.

125. Ansari, ZJ; Sadr, A; Moezizadeh, M; Aminian, R; Ghasemi, A; Shimada, Y; Tagami, J; Ansari, SJ; Moayedi, S. Effects of one-year storage in water on bond strength of selfetching adhesives to enamel and dentin. Dent Mater J. 2008, v. 27, n.2, p.266-72.

126. Mine, A; De Munck, J; Cardoso, MV; Van Landuyt, KL; Poitevin, A; Kuboki, T; Yoshida, Y; Suzuki, K; Lambrechts, P; Van Meerbeek. Bonding effectiveness of two contemporary self-etchin adhesives to enamel and dentin. J Dent . 2009, v. 37, n. 9, p. 872-883.

127. Versluis, A; Tantbirojn, D; Douglas, WH. Why do shear bond tests pull out dentin? J Dent Res. 1997, v. 76, n. 6, p.1298-1307.

128. Ishikawa, A; Shimada, Y; Foxton, RM; Tagami, J. Micro-tensile and micro-shear bond strengths of current self-etch adhesives to enamel and dentin. Am J Dent. 2007, v. 20, n. 3, p.161-166.

129. Erhardt, MC; Shinohara, MS; Bedran-Russo, AK; Amaral, CM; Pimenta, LA. Effect of long-term water storage on etch-and-rinse and self-etching resin-dentin bond strengths. Gen Dent. 2008; v.56, n.4, p.372-377.

130. Burrow, MF; Kitasako, Y; Thomas, CD; Tagami, J. Comparison of enamel and dentin microshear bond strengths of a two-step self-etching priming system with five allin-one systems. Oper Dent. 2008, v.33, n.4, p.456-60.

131. Luhrs, AK; Guhr, S; Gunay, H; Geursten, W. Shear bond strength of selfadhesive resins compared to resin cements with etch and rinse adhesives to enamel and dentin in vitro. Clin Oral Investig. 2010, v. 14, n.2, p.193-199. 